\title{
Educação audiovisual: uma proposta para a formação de professores de Ensino Fundamental e de Ensino Médio no Brasil
}

Tese apresentada ao Programa de Meios e Processos Audiovisuais da Escola de Comunicações e Artes da Universidade de São Paulo, para obtenção do título de doutor.

Área de concentração: Meios e Processos Audiovisuais

Orientadora: Prof. Dra. Maria Dora Genis Mourão 
Autorizo a reprodução e divulgação total ou parcial deste trabalho, por qualquer meio convencional ou eletrônico, para fins de estudo e pesquisa desde que citada a fonte.

Catalogação na publicação

Serviço de Biblioteca e Documentação

Escola de Comunicações e Artes da Universidade de São Paulo

Rizzo Junior, Sergio Alberto

Educação audiovisual : uma proposta para a formação de professores de Ensino Fundamental e de Ensino Médio no Brasil/Sergio Alberto Rizzo Junior -

São Paulo : S. A. Rizzo Junior, 2011.

$189 \mathrm{p}$.

Tese (Doutorado) - Escola de Comunicações e Artes / Universidade de São Paulo.

Orientadora: Prof ${ }^{a}$ Dr $^{a}$ Maria Dora Genis Mourão

1. Audiovisuais na educação 2. Formação de professores 3. Educação escolar básica I. Mourão, Maria Dora Genis II. Título.

CDD 21.ed. - 371.33 
Nome: RIZZO JUNIOR, Sergio Alberto

Título: Educação audiovisual: uma proposta para a formação de professores de Ensino Fundamental e de Ensino Médio no Brasil

Tese apresentada ao Programa de Meios e Processos Audiovisuais da Escola de Comunicações e Artes da Universidade de São Paulo, para obtenção do título de doutor.

Aprovado em:

Banca Examinadora

Prof.Dr. Instituição:

Julgamento:

Assinatura:

Prof.Dr. Instituição:

Julgamento: Assinatura:

Prof.Dr. Instituição:

Julgamento: Assinatura:

Prof.Dr. Instituição:

Julgamento: Assinatura:

Prof.Dr. Instituição:

Julgamento: Assinatura: 
para Lora, minha mãe

à memória de Sergio, meu pai, e de Luiz Antonio, meu irmão 
À Prof. Dra. Maria Dora Mourão, pelo apoio e carinho, desde o mestrado.

Ao Prof. Dr. Ângelo Piovesan Neto, ao Prof. Dr. Eduardo Morettin, ao Prof. Dr. Julio Groppa Aquino, ao Prof. Dr. Ismail Xavier, ao Prof. Dr. Ismar Soares e à Prof. Dra. Marilia Franco, pelas contribuições ao projeto, em diferentes estágios.

A Alexandre Le Voci Sayad, Amir Labaki, Delma Costa, Fred Botelho, Lizandra Almeida, Lucia Houaiss, Patricia Durães, Paulo Pereira de Lima, Stela Barbieri, Zita Carvalhosa e William Hinestrosa, pelas parcerias.

A Alexandre Barbosa, Cláudia Mogadouro, Guilherme Bryan, Juliana Jardim Barboza, Luiz Costa Pereira Junior e Rubem Barros, pela troca de ideias e informações.

A Andrea Hossne e Daniela Santos, pelo auxílio na reta final.

A Beatriz Peres, Bias Arrudão, Leonardo Cruz e Maria Amélia Dalsenter, pela amizade e cumplicidade.

A Ana Claudia Oliveira, por muita coisa.

A todos os funcionários da Secretaria de Pós-Graduação, dos Programas de Pós-Graduação em Meios e Processos Audiovisuais e em Ciências da Comunicação, e do Serviço de Biblioteca e Documentação da Escola de Comunicações e Artes da Universidade de São Paulo, pela colaboração.

Seria impossível mencionar aqui todos os educadores, profissionais de comunicação e alunos com os quais tive a oportunidade de conversar, nos últimos 15 anos, sobre o tema desta pesquisa. A todos eles, que involuntariamente desempenharam papel importante na trajetória que conduziu a este trabalho, meu profundo agradecimento. 
"O cinema será o teatro, a escola e o jornal de amanhã."

Charles Pathé (1863-1957), empresário francês

e um dos pioneiros das indústrias cinematográfica e fonográfica, em 1901; ele vendeu sua participação na Société Pathé Frères

em 1929 e se afastou do cinema

"Senhor, por que as outras turmas saem para dar passeios e a gente não vai a parte alguma? Só ficamos aqui sentados falando numa porcaria de gravador. Por quê? Sim, sim, disse a turma. Por quê?

As outras turmas vão ao cinema. Por que a gente não pode ir ao cinema?

\section{$(\ldots)$}

Um guarda parou na minha frente.

Sim. Sou o professor.

Então o que essas meninas estão fazendo na rua Quarenta e Dois no meio do dia?

Fiquei vermelho, confuso. Vamos ao cinema.

Olha só. Vão ao cinema. É para isso que a gente paga imposto. Tudo bem, seu professor, circulando aí com essas meninas."

Frank McCourt, professor e escritor irlandês, descrevendo a ocasião em que decidiu levar as 29 alunas de uma de suas turmas de inglês da 9a. série da Escola Secundária Seward Park -- "um coeso bando de vinte e nove garotas negras à solta no mundo, de voz rouca, desafiadoras, jogando pipocas umas nas outras, gritando para a cabine de projeção" -- a um cinema da Rua 42, em Nova York, em 1968, para assistir ao filme Cold turkey, no livro de memórias Ei, professor 
RIZZO JUNIOR, Sergio Alberto. Educação audiovisual: uma proposta para a formação de professores de Ensino Fundamental e de Ensino Médio no Brasil. 2011. 150 p. Tese (Doutorado) - Escola de Comunicações e Artes, Universidade de São Paulo, 2011.

Este trabalho apresenta um arcabouço conceitual para ser aplicado à formação de professores, em curso universitário de especialização (lato sensu), para o desenvolvimento de atividades no campo da linguagem e da produção audiovisual. Profissionais da Educação Básica, que compreende os nove anos do Ensino Fundamental e os três anos do Ensino Médio, representam o público preferencial dessa formação. As diretrizes aqui propostas correspondem também às oportunidades para a inserção do audiovisual na Educação Infantil, no Ensino Superior e na Educação de Jovens e Adultos. O referencial aqui estabelecido procura estar em sintonia com o atual cenário no campo da comunicação social e das artes, bem como com as diretrizes educacionais do país. A partir desse mapeamento conceitual, devidamente conectado com o desenvolvimento do audiovisual ao longo do século XX e na primeira década do século XXI, configura-se a grade de um curso de especialização voltado para a qualificação, nessa área, de profissionais egressos dos cursos de formação de professores e de gestores de educação. 0 resultado pode ser adaptado para dar origem a uma licenciatura em audiovisual e também, a partir do desmembramento de seus eixos, a cursos de formação pontuais oferecidos por redes de ensino ou estabelecimentos isolados. 0 uso do termo "educação audiovisual" busca traduzir compreensão mais aguda dos fenômenos que, sob efeito do que se convencionou chamar de "convergência de meios", de "revolução digital" e de "economia do audiovisual", geraram transformações profundas nos campos do cinema, da televisão e do vídeo, interligados nas esferas da linguagem, da produção, da difusão e da recepção.

Palavras-chave: Educação audiovisual. Formação de professores. Educação escolar básica. Pedagogia. Comunicação. Cinema. Televisão. Vídeo. 
RIZZO JUNIOR, Sergio Alberto. Educação audiovisual: uma proposta para a formação de professores de Ensino Fundamental e de Ensino Médio no Brasil. 2011. 150 p. Tese (Doutorado) - Escola de Comunicações e Artes, Universidade de São Paulo, 2011.

This dissertation presents a conceptual framework to be applied to the formation of teachers, in a university course of specialization (lato sensu), for the development of activities in the field of audiovisual language and production. Professionals of Basic Education, which encompasses the nine years of Elementary School and the three years of Middle School, make up the preferential public for this formation. The directives proposed here correspond also to the opportunities for the insertion of audiovisual in Early Education, Higher Education and Adult and Youth Education. The referential established here seeks to be attuned to the current scenario in the area of social communications and arts, as well as with Brazil's education directives. From that conceptual mapping, which here is connected to the development of audiovisual along the 20th Century and the first decade of the 21 st Century, is configured the grid of a course of specialization directed to the qualification, in this area, of professionals from the courses of teachers' and education managers' formation. The results may be adapted to become the source of a teaching degree in audiovisual and also, by separating its main axes, of targeted formation courses offered in education networks or in individual establishments. The use of the term "audiovisual education" seeks to translate a more accurate comprehension of the phenomena that, under the effect of what has been agreed to be called "media convergence", "digital revolution" and "audiovisual economics", have generated deep changes in the fields of cinema, television and video, which are interconnected in the spheres of language, production, diffusion and reception.

Key words: Media literacy. Teacher's formation. Basic school education. Pedagogy. Communication. Cinema. Television. Video. 
Introdução: telas e processos. 11

1. Da "higiene mental" à "educação integral"...................................24

1.1. O cinema é necessário à educação: uma proposta conservadora...........28

1.2. O cinema e a TV são necessários à educação: uma proposta transformadora......................................................................... 45

2. De paradigmas a inovações.........................................................61

2.1. Cinema e educação: uma abordagem paradigmática.............................63

2.2. Televisão, vídeo e educação: uma abordagem inovadora.......................71

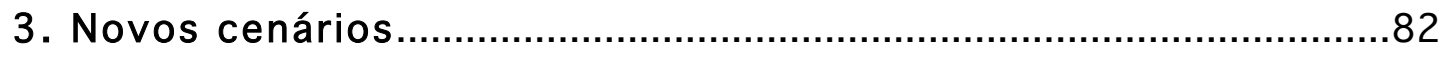

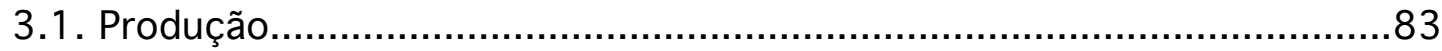

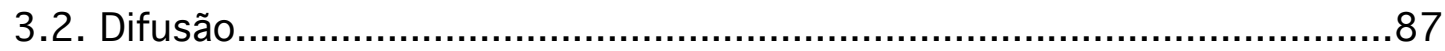

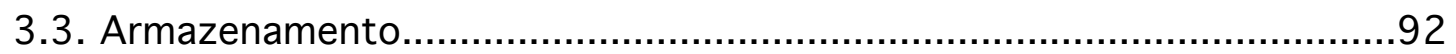

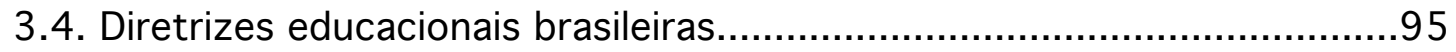

3.4.1. Ensino Fundamental....................................................................... 95

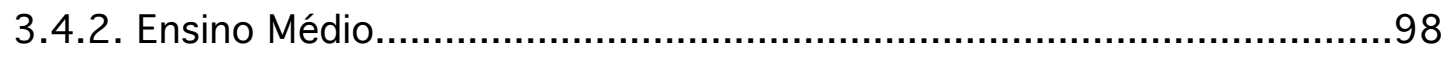

4. Princípios, competências e eixos temáticos...............................101

4.1. História da educação audiovisual..................................................104

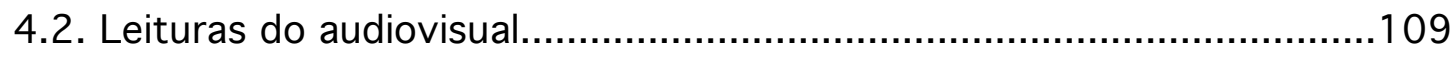

4.3. Política e economia do audiovisual.....................................................113

4.4. Audiovisual e cibercultura...........................................................116

4.5. Estratégias de educação audiovisual................................................118

4.5.1. Realização audiovisual na escola.....................................................119

5. Objetivos, grade curricular e conteúdos....................................122

5.1 . Objetivos............................................................................... 122

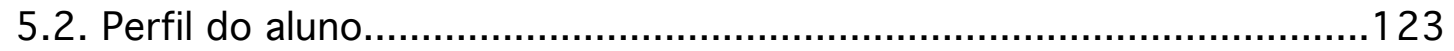

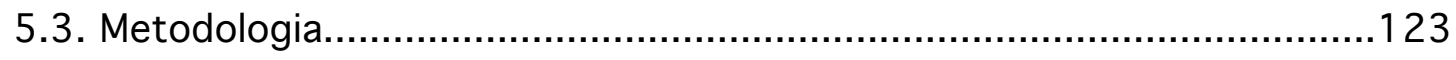

5.4. Duração e carga horária.................................................................124

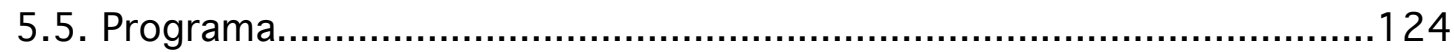

5.5.1. Organização por eixos temáticos..............................................125 
5.5.2. Organização por módulos semestrais..........................................126

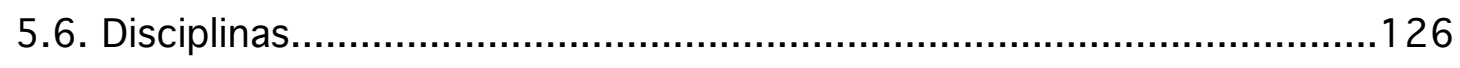

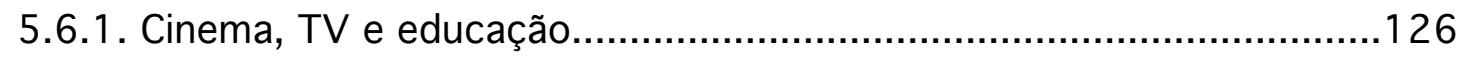

5.6.2. Mídia, infância e juventude...................................................128

5.6.3. Fundamentos da educomunicação e ecossistemas comunicacionais................................................................. 130

5.6.4. Fundamentos da crítica do audiovisual.........................................131

5.6.5. Laboratório de crítica I, II e III.....................................................132

5.6.6. Audiovisual e representação........................................................ 133

5.6.7. Política e economia do audiovisual................................................134

5.6.8. Ciberespaço, cibercultura e redes................................................136

5.6.9. Produção audiovisual e meios digitais............................................137

5.6.10. Planejamento pedagógico para a educação audiovisual..................138

5.6.11. Programação e mediação do audiovisual na escola........................140

5.6.12. Realização audiovisual I, II e III.................................................... 142

5.7. Atividades complementares................................................... 143

5.8. Monografia ou trabalho de conclusão de curso...................................144

Conclusões: nem apocalíptica, nem integrada.................................... 145

Referências bibliográficas..............................................................149

Apêndices.............................................................................. 164

Apêndice A: rascunho autobiográfico de um espectador...........................164

Apêndice B: grade alternativa do curso de especialização em audiovisual..176

Apêndice C: programa de curso sobre cinema e educação.........................179 


\section{Telas e processos}

Cinema na educação, televisão na educação, vídeo na educação, audiovisual na educação: quando essas expressões são usadas, a relação de subordinação - uma coisa em outra, o que implica uma coisa submetida hierarquicamente à outra, contida na outra - sugere que o primeiro elemento será usado apenas como instrumento pelo segundo. Cinema, televisão e vídeo - ou, em termos mais abrangentes, o audiovisual - recrutados no domínio das artes e das comunicações para prestar serviços à escola como ferramenta paradidática, utilizada com o objetivo de trabalhar conteúdos de aprendizagem.

Não há, a rigor, nenhum equívoco radical nesse entendimento. De fato, como recurso de apoio a aulas e demais atividades de variadas disciplinas, o audiovisual é adotado por incontáveis professores para diferentes propósitos (meramente informativos, na abordagem mais simplificada, ou geradores de reflexões e debates, em modelos mais elaborados). Os resultados costumam ser diretamente proporcionais ao repertório audiovisual do educador e à sua capacidade de aproveitar-se dessa linguagem para alcançar os objetivos previstos.

Trata-se, no entanto, de maneira restrita de analisar o potencial dos meios audiovisuais na formação de crianças e jovens. A apreciação e a produção de obras que geram seu sentido por meio da articulação de imagens e sons podem estabelecer também outras conexões com a Educação Básica, na forma de disciplina curricular (obrigatória ou optativa), de conteúdo específico inserido em disciplina curricular mais abrangente (obrigatória ou optativa), de atividade extracurricular e de prática mobilizadora de projetos interdisciplinares. 
Em todas essas modalidades, o audiovisual vem se enraizando no cotidiano escolar do Ensino Fundamental e do Ensino Médio'. O fenômeno tem ocorrido mais em virtude de condicionantes sociais (fruto da ampla presença dos meios audiovisuais no mundo contemporâneo, especialmente em países como o Brasil, em que a maior parte da população recorre à TV, e não aos meios impressos, para diversão, informação e mesmo integração social ${ }^{2}$ ), de determinantes de administração escolar (como a aquisição de equipamentos e de acervos, que termina por impor, ou ao menos tentar impor, o seu uso) e do interesse pessoal de inúmeros educadores (eles também, afinal, consumidores, entusiastas e às vezes produtores de audiovisual) do que de uma política de formação para o uso do audiovisual presente nas grades curriculares dos cursos cujos egressos se tornam profissionais da Educação Básica.

Este trabalho adota como objeto de pesquisa a identificação do repertório básico de conhecimentos hoje recomendáveis imprescindíveis, talvez - para que atividades relacionadas à linguagem audiovisual sejam desenvolvidas no âmbito escolar brasileiro em sintonia com o atual cenário no campo da comunicação social e das artes, bem como com as diretrizes educacionais do país. Tais conhecimentos, conceituais e aplicados, devem levar em conta especificidades do nosso tempo que, de um lado, tornam assustadoramente anacrônicos os programas de disciplinas voltadas, nos cursos tradicionais de formação de professores da Educação

\footnotetext{
${ }^{1}$ Minha experiência pessoal como aluno de Educação Básica, relatada no Apêndice A, refere-se a um tempo, nos anos 1970 e 1980, em que o cenário era muito distinto.

${ }^{2} \mathrm{O}$ Instituto Brasileiro de Geografia e Estatística estimou, em 1999, que 87,5\% dos 40 milhões de domicílios brasileiros dispunham de televisão e $82,5 \%$, de geladeira. A diferença correspondia a cerca de 2 milhões de domicílios onde, em tese, um aparelho de TV era considerado mais importante do que o outro eletrodoméstico. Ver PEREIRA JUNIOR, 2002.
} 
Básica, para o estudo das "novas tecnologias" no cenário educacional (como se o vertiginoso avanço tecnológico experimentado nas últimas duas décadas no campo das comunicações, sem paralelo na história da humanidade, já não tornasse precocemente obsoletas as tentativas de separar as "velhas" tecnologias das "novas", das "novíssimas" e das "mais novas ainda").

Essas especificidades, de outro lado, obrigam a uma forte revisão das diversas práticas já executadas ao longo da segunda metade do século XX, no âmbito governamental e também no domínio das organizações não-governamentais, com o objetivo de proporcionar capacitação a professores para o uso da linguagem audiovisual na escola. Os conteúdos desses programas de qualificação -- oferecidos com base no diagnóstico acertado de que os cursos de formação universitária de educadores não foram capazes de prepará-los satisfatoriamente para tais atividades -- tendem a contemplar um cenário também anacrônico, que despreza ou miniminiza, entre outros aspectos, os efeitos da "revolução digital" sobre o cotidiano de professores e de alunos (e, por que não, de toda a sociedade) e a configuração de um novo ambiente para a produção, a circulação, o consumo e a apreciação de obras audiovisuais.

Para que o estudo desse objeto de pesquisa adquirisse contornos bem concretos, este trabalho optou por apresentar um arcabouço conceitual que possa ser aplicado à formação de professores para o desenvolvimento de atividades no campo da linguagem e da produção audiovisual, sobretudo no âmbito da Educação Básica brasileira, que compreende os nove anos do Ensino Fundamental e os três anos do Ensino Médio; penso, no entanto, que esses conhecimentos correspondam também às oportunidades para a inserção do audiovisual na Educação Infantil, no Ensino Superior e na 
Educação de Jovens e Adultos. O objetivo-chave da pesquisa é o de desenhar referencial que corresponda ao cenário no campo da comunicação social e das artes neste início de século, e que também explore as oportunidades para o uso do audiovisual previstas pelas diretrizes educacionais em vigor no Brasil.

A partir desse mapeamento conceitual, devidamente conectado com o desenvolvimento do audiovisual ao longo do século XX e na primeira década do século XXI, configura-se ao final do trabalho a grade de um curso de especialização voltado para a formação, nessa área, de profissionais egressos tanto dos cursos de audiovisual como daqueles responsáveis pela formação de professores e de gestores de educação. Acredito que o resultado possa ser adaptado para dar origem a uma licenciatura em audiovisual; e também, a partir do desmembramento de seus eixos, a cursos de formação pontuais oferecidos por redes de ensino ou estabelecimentos isolados.

A ênfase na proposta formativa, com o planejamento de uma ação educacional direcionada à qualificação de educadores, faz com que este trabalho percorra um caminho metodológico diverso daqueles que se debruçaram sobre o histórico das relações entre o cinema e a educação no Brasil. Cabe aqui destacar, no entanto, pesquisas nesse campo que iluminam os dilemas já enfrentados por políticas de incentivo ao uso do audiovisual na Educação Básica. Morrone (1997) cobre o período que vai de 1920 a 1945, marcado pelos primeiros debates e críticas em torno da produção cinematográfica comercial, e pela consequente proposta, articuladas por grupos conservadores, de agenda positivista para o cinema e a escola nacionais, traduzida na criação, durante o Estado Novo, do Instituto Nacional de Cinema Educativo. 
Experiência posterior e também referencial para esse campo, realizada de 1988 a 1997 no âmbito da Fundação para o Desenvolvimento da Educação (FDE) da Secretaria de Estado da Educação de São Paulo, incluindo a criação de "videoteca pedagógica" e a publicação de material de apoio ao professor, é analisada por Silva (2009). Outras pesquisas recentes ajudam a compreender, de forma mais pontual, como têm sido estruturadas na Educação Básica brasileira, também nos últimos 15 anos, ações que procuram inserir o audiovisual na dinâmica escolar, como as de Oliveira (2003), que analisa práticas de uso da televisão e do vídeo em uma escola pública de São Paulo com base nos conceitos da educomunicação; de Cipolini (2008), que mapeou a utilização do cinema como ferramenta paradidática em 25 escolas de Ensino Médio da rede pública de São Paulo, em 2006 e 2007; e de Beskow (2008), que, à luz do estudo da aplicação de um projeto educomunicativo - desenvolvido em parceria pela Escola do Futuro da Universidade de São Paulo e pela FDE, de 2002 a 2005 - em duas escolas públicas de São Paulo, examina como o conceito de "novas tecnologias" chega às redes de ensino.

Difunde-se em círculos escolares a ideia de que o cinema, a televisão e os computadores correspondem a "telas que ensinam" ${ }^{3}$. Trata-se de visão ingênua e um tanto ultrapassada na história da pedagogia: se há algo capaz de "ensinar", no sentido de produção de conhecimento, é o processo pelo qual essas telas (na verdade, o que elas exibem, e o que eventualmente se produza, no âmbito escolar, para que seja nelas exibido) passam a ter lugar no cotidiano de ensino

\footnotetext{
${ }^{3}$ Um dos livros dedicados ao tema (NETTO, 1998) leva o título de Telas que ensinam: mídia e aprendizagem: do cinema ao computador.
} 
e aprendizagem ${ }^{4}$. Para dar conta em sua plenitude das especificidades desse processo, seria recomendável formação específica.

Cabe lembrar que o raciocínio das "telas que ensinam" tem, além do que foi apontado acima, ênfase meramente conteudista e inequivocamente autoritária, por supor que as obras exibidas nessas telas carregam um sentido único (aquele, supõe-se, identificado pelo educador que recorre a elas) que estaria sobreposto à forma (quando, na verdade, é produzido por ela) e que ignora a possibilidade de múltiplas leituras a serem articuladas pelo espectador (aluno).

Eis aí outra razão para que se acredite na oportunidade da qualificação nessa área: mesmo exercendo apenas o papel de ferramenta paradidática, o audiovisual encerra universo particular de articulação de conceitos e ideias que interfere diretamente nas funções supostamente "ilustrativas" de conteúdos disciplinares. Não há como se referir aos sentidos de uma obra, com a preocupação de explorá-los e desvendá-los, sem fazer alusão aos mecanismos de linguagem e às circunstâncias de produção e difusão que contribuíram, organicamente ou não, para gerá-los. A formação específica contribuiria para ampliar essa compreensão, tão cara à modernidade.

Considero estratégico o uso do termo audiovisual por acreditar que traduza compreensão mais aguda dos fenômenos que, sob efeito do que se convencionou chamar de "convergência de meios", de "revolução digital" e de "economia do audiovisual", geraram transformações profundas nos campos do cinema, da televisão e do vídeo. Hoje, esses campos - que, convém registrar, jamais foram independentes uns dos outros, tanto em aspectos estéticos como em econômicos - se interligam de tal maneira, nas esferas da linguagem,

\footnotetext{
${ }^{4}$ A obra do psicólogo soviético Lev Vygotsky (1896-1934) é referencial para o entendimento dos processos de aprendizagem.
} 
da produção e da difusão, que soa terrivelmente anacrônico encará-los de modo estanque.

Não por acaso, a Escola de Comunicações e Artes da Universidade de São Paulo optou, já em 2000, por batizar de Curso Superior do Audiovisual a fusão de seus antigos cursos de Cinema e de Rádio e TV (que, em estágio intermediário, deram origem ao curso de Cinema e Vídeo).

No Brasil, a conjugação "cinema na educação" (e seus equivalentes) prevalece amplamente, em relação a "televisão na educação" e "audiovisual na educação", e continua a ser usada por escolas e professores para definir uma gama de atividades que, em primeiro lugar, já não corresponde propriamente ao que representa o cinema tal como o entendemos a partir da sua configuração como espetáculo de massas, na virada do século XIX para o século XX.

A preferência é natural, se lembrarmos que o cinema foi a primeira manifestação audiovisual, produziu imensa multiplicidade estética, e constituiu bibliografia extensa e expressiva. Observa-se, no entanto, certo fetiche na opção por essa terminologia, como se ao cinema coubesse um título de nobreza e, aos demais meios que se fazem valer da conjugação entre imagem e som, apenas o estigma da vulgaridade, o que os tornaria - eis o ponto - indignos de pôr os pés na escola.

Identifica-se também, nessa predileção pelo uso do termo até mesmo quando decididamente não é de cinema que se fala, e sim de vídeo, uma entrega indefesa ao lugar ocupado pelo primeiro no mercado de bens simbólicos, como se a circulação de determinada obra pelos fluxos do circuito cinematográfico e/ou do comércio de DVDs - desde que aferida pelos mecanismos de consagração social, aqui representados sobretudo pela crítica - lhe conferisse um 
inquestionável "padrão de qualidade". Esse entendimento opera ainda certa mistificação, pois o cinema, stricto sensu, continua a ser atividade ao alcance de poucos, em virtude de fatores econômicos e tecnológicos.

Optar pelo uso do termo audiovisual contribui, na minha avaliação, para uma espécie de "dessacralização". Seria favorecida, dessa forma, a visão de que se expressar por meio de imagens e sons, no mundo em que vivemos, representa prática ao alcance de um número muito maior de pessoas - a rigor, de todos os que possuam pré-requisitos hoje acessíveis a quase todas as camadas da população, como câmeras portáteis (inclusive as instaladas em telefones celulares) e computadores -- do que os poucos capazes de fazer a travessia profissional para a atividade cinematográfica.

Em segundo lugar, e ainda mais importante, o uso da palavra cinema opera uma delimitação do campo do audiovisual que, no domínio da Educação Básica, tem desprezado historicamente a televisão - exceto nas circunstâncias em que ela se transforma em meio para a transmissão de conteúdo de caráter "educacional", principalmente o gerado por projetos governamentais por meio de emissoras públicas ou mesmo privadas.

A já mencionada presença massiva da televisão no cotidiano do País pede, ao contrário, que ela mereça atenção da escola, e que essa atenção não se resuma apenas a uma atitude classificatória (isto é "bom", aquilo é "ruim"). Entender o papel de mediação da televisão nas sociedades contemporâneas, e no Brasil em especial, passa evidentemente por entender a sua programação, mas vai muito além disso.

Por fim, a opção pelo termo cinema tende a minimizar, em especial na última década, o papel dos meios digitais na produção e 
difusão de obras audiovisuais egressas do cinema, da televisão e do vídeo, assim como as produzidas especificamente para circulação e consumo nesses meios.

É no campo de estudos dedicado à convergência entre o cinema e a educação, no entanto, que o primeiro capítulo deste trabalho busca ideias balizadoras para organização de arcabouço conceitual sobre a presença do audiovisual na escola. Afinal, por razões históricas, é nesse campo que primeiro se identifica o pensamento sobre a potencialidade de uso do audiovisual para fins educacionais, em alguns casos a partir de um diagnóstico negativo do papel exercido pelo cinema convencional de ficção - o chamado "cinema comercial", para consumo de massas - sobre usos e costumes, principalmente de crianças e jovens.

No pensamento do brasileiro Joaquim Canuto Mendes de Almeida e do italiano Roberto Rossellini revelam-se paradigmas já comprometidos pela atual dinâmica do audiovisual, do sistema educacional e da própria sociedade, e que representam, portanto, posturas e práticas que este trabalho considera equivocadas, ainda que possivelmente bem intencionadas, porque hoje soam ingênuas, mas também porque defendem posturas autoritárias, paternalistas ou funcionalistas.

O primeiro capítulo aponta também, no pensamento de Almeida e Rossellini, avaliações da presença do audiovisual na escola que problematizam aspectos ainda fulcrais dessa relação, e que, assim, podem se submeter a um processo de revisão, sem prejuízo do sentido original, para que seu uso referencial auxilie na configuração de um arcabouço teórico coerente com as oportunidades e os desafios da atualidade. 
O projeto de "cinema educativo" de Almeida se estabelece, no início na década de 1930, como um dos marcos iniciais das reflexões mais aprofundadas sobre o tema, ao acreditar na "força sugestiva" das "imagens acopladas às dimensões sonoras". Sua visão instrumental e pragmática, apresentada no livro Cinema contra cinema: bases gerais para um esboço de organização do cinema educativo no Brasil, publicado em 1931, propõe-se a associar os recursos do que considerava "bom cinema" a uma espécie de "projeto regenerador" da sociedade brasileira. $\mathrm{O}$ autor tinha a anunciada pretensão de lançar as "bases gerais para um esboço do cinema educativo no Brasil".

Rossellini partilha do mesmo entusiasmo de Almeida pelo futuro das relações entre o audiovisual e a educação, mas adota postura mais democrática e contempla o vídeo e a televisão em suas propostas. Além do aspecto referencial que essas ideias representam, inclusive no que diz respeito à sua carga de preconceito (sobretudo no caso de Almeida) e de certa ingenuidade (mais no caso de Rossellini), ambos foram escolhidos para abrir a reflexão conceitual sobre educação audiovisual porque representam lugares bem distintos: o primeiro, advogado de formação e juiz, aborda o tema de perspectiva que se propõe "externa" ou "estrangeira", característica de quem chegou a atuar no campo do cinema, mas optou por não se inserir nele, muito menos no campo da educação formal, e tem a preocupação cidadã -- e não a de um agente de qualquer um daqueles campos, que agisse em defesa de pautas corporativas -- de pensar sobre eles e de, em certo sentido, vigiá-los; o segundo, realizador de cinema e TV, observa as conexões entre audiovisual e educação sob o ponto de vista de quem procurou ao longo da maior parte de sua carreira, na esfera da produção e da difusão, promovê-las. 
Como se verá, o que ambos propuseram e imaginaram tem a capacidade de condensar as principais linhas de pensamento -conservadoras e progressistas, de "direita" e de "esquerda" -- sobre a missão educacional do audiovisual no século 20, e deve ser invocado ainda hoje como balizas simbólicas em torno das quais aprofundar, de maneira verticalizada, a investigação das coordenadas de formação de profissionais para a educação audiovisual.

No segundo capítulo, a busca de referenciais se ocupa de propostas bem mais concretas do que as de Almeida e Rossellini. No campo do cinema, o estudo publicado em 1961 pela Organização das Nações Unidas para a Educação, a Ciência e a Cultura (Unesco), sob coordenação do pesquisador holandês Jan Marie Lambert Peters, para estabelecer diretrizes sobre a educação cinematográfica; no campo da televisão e do vídeo, a obra do espanhol Joan Ferrés, condensada em livros publicados nos anos 1990.

Em ambos os casos, as abordagens revelam avanços notáveis na compreensão das relações entre o audiovisual e a educação, e se pautam pelo diálogo direto com educadores. Não mais se trata, como no caso de Almeida e Rossellini, de imaginar cenários ideais para inserir o cinema e a televisão no âmbito escolar. O estudo da Unesco e a obra de Ferrés apontam, objetivamente, para as condições em que essa inserção pode (para os autores, deve) ser realizada, formulando princípios capazes de orientar práticas.

Ainda que formuladas em circunstâncias que já não correspondem às atuais, tanto no domínio do audiovisual como no do cotidiano escolar, essas abordagens empregam conceitos mais próximos das oportunidades e dos desafios do cenário atual. São referenciais para o entendimento de estágio intermediário de amadurecimento em relação ao tema desta pesquisa, sobretudo no que 
diz respeito a Ferrés, uma vez que o campo de estudos sobre televisão e educação se constituiu historicamente em condições distintas daquelas que fundaram o campo de estudos sobre cinema e educação. Enquanto o cinema, passada uma fase inicial de resistência à sua produção industrial, estabeleceu prestígio de manifestação artística de acordo com o entendimento dominante nos círculos acadêmicos, na mídia e no próprio universo escolar, a televisão se vê ainda hoje associada ao estigma de divertimento de massas sem nenhuma densidade cultural.

No terceiro capítulo são identificadas e analisadas as principais características dos novos cenários do audiovisual e da educação que, necessariamente, impactam hoje as relações entre um e outro. Diante dessas transformações, acentuadas sobretudo nos últimos 10 anos, consideramos que não se possa conceber a educação audiovisual à margem do cenário convergente que, além de provocar mudanças no aparato tecnológico a ser utilizado em diversas práticas, interfere também em aspectos conceituais associados aos modos de expressão por meio de imagens e sons.

No campo do audiovisual, o novo cenário, de abrangência internacional, está baseado no desenvolvimento de novas tecnologias de produção, difusão e armazenamento, além de uma nova configuração dos mercados pelos quais escoam as obras e dos meios alternativos pelos quais circulam também manifestações audiovisuais desvinculadas de preocupações mercadológicas. No campo da educação, as últimas duas décadas registraram, no Brasil, importantes reformas curriculares na Educação Básica, favorecendo a presença do audiovisual na escola mesmo em situações nas quais ela não é explicitamente prevista, mas contemplada por diretrizes que a encampam. 
O quarto capítulo apresenta os eixos temáticos em torno dos quais se organiza esta proposta de formação em educação audiovisual, em consonância com os conceitos e os cenários midiáticos e educacionais discutidos nos capítulos anteriores. Esses eixos estabelecem horizontes de conteúdo a serem trabalhados, traçando pontes em direção aos campos de estudos da arte-educação e da educomunicação.

No quinto capítulo esse referencial é organizado na forma de curso de especialização voltado para a formação em educação audiovisual. Parte de seu programa pode ser adaptada e incorporada por cursos de licenciatura interessados em qualificar profissionais para o desenvolvimento, em ambientes escolares, de atividades relacionadas à linguagem e à produção audiovisual. A estrutura do curso de especialização pode também servir como referencial para ações de qualificação de professores a serem implantadas por redes de ensino e por escolas isoladas. 


\section{Da "higiene mental" à "educação integral"}

As três primeiras décadas do século XX consolidaram o cinema como um espetáculo de massas, cumprindo a previsão feita no ensaio Manifesto das sete artes, do italiano Ricciotto Canudo (18771923), escrito em 1911 mas só publicado em 1914: a arte da "síntese total", nascida nos estertores do século XIX a partir da conjugação entre "Máquina" e "Sentimento", já deixava de balbuciar apenas suas primeiras palavras, como um bebê, e entrava na infância; segundo ele, a velocidade de seu desenvolvimento parecia pavimentar rapidamente o caminho até a adolescência, quando despertaria seu "intelecto" e multiplicaria suas "manifestações" (In ROMAGUERA I RAMIÓ, 1989, pp. 15-18).

De fato, foram estabelecidas naquele período as bases do cinema narrativo clássico, modelo que se tornaria hegemônico no domínio industrial; os longas-metragens dirigidos nos EUA, na década de 1910, por D. W. Griffith (1875-1948) correspondem a um compêndio dos procedimentos de câmera e montagem estruturais para a constituição de ponto de vista onipresente, onisciente e invisível na narrativa de ficção audiovisual ${ }^{5}$. Em paralelo à fundação desse modelo, estruturouse nesse mesmo período a atuação de grandes companhias produtoras e distribuidoras norte-americanas, que se beneficiaram do impacto causado pela I Guerra Mundial sobre seus rivais europeus para dar

\footnotetext{
5 O nascimento de uma nação (The birth of a nation, 1915) e Intolerância (Intolerance: love's struggle throughout the ages, 1916), longas-metragens de Griffith, consolidaram o então já variado repertório de procedimentos desenvolvido pelo modelo narrativo clássico graças ao trabalho de numerosos realizadores.
} 
passo decisivo rumo à globalização de suas atividades e à consequente ampliação de seu público ${ }^{6}$.

A comunhão entre a produção norte-americana e o grande público - parte do qual tem a sensação de "aprender" com ela lições históricas, geográficas e comportamentais - foi registrada pelo escritor italiano Cesare Pavese (1908-1950) em Salut Masino, texto de 1929:

Uma tarde passada num pequeno cinema de subúrbio, entre operários e gente do povo, diante de uma telinha que balançava assim como o piano que a acompanhava, era para o jovem estudante a mais feliz das tardes. Masino se refugiava no cinema, que foi para nossa juventude uma verdadeira bênção. Essas semanas intermináveis se fragmentavam em inúmeras horas passadas naquele universo que, embora familiar, era sempre fascinante. Masino amava os seriados americanos. Vendo-os, orgulhava-se também de aprender cada vez alguma coisa e de viver um mundo novo. Esses filmes eram fabricados especialmente, diziam, para cinemas de bairro. [...] Os filmes americanos. Não custavam caro e viam-se as coisas mais deliciosas. [...] Nos bairros do centro dizia-se que eram apenas pequenas obras banais, sem afetação e sem vida, mas Masino estava de fato convencido de que, assistindo a esses espetáculos, aprendia a viver (In PRIEUR, 1993, p. 125-126).

Se o alvorecer da indústria apontava para a expansão do negócio e sua crescente penetração nas camadas populares, reforçada nos EUA pela crise de 1929 e a adoção das salas de cinema como um espaço de fuga das atribulações do cotidiano ${ }^{7}$, as correntes de vanguarda das

\footnotetext{
${ }^{6}$ Para dados sobre o desenvolvimento da indústria cinematográfica dos EUA nas primeiras décadas do século XX e a conquista de seu papel hegemônico no mercado internacional, cf. FINLER, 1988, e SCHATZ, 1991.

${ }^{7}$ O longa-metragem $A$ rosa púrpura do Cairo (The purple rose of Cairo, 1985), de Woody Allen, aborda de maneira sintética e romântica o papel fantasioso do cinema hollywoodiano na vida dos trabalhadores norte-americanos durante a Grande Depressão.
} 
filmografias soviética - com destaque para as pesquisas de Sergei M. Eisenstein (1898-1948) e do grupo Cine-Olho, liderado por Dziga Vertov (1896-1954), no campo da montagem -, alemã e francesa ilustraram, na década de 1920, a capacidade de o cinema expressar visões de mundo complexas, gerando, em alguns casos, polêmicas agudas na sociedade, com intensa repercussão na imprensa. Registrese, por exemplo, como o diretor espanhol Luis Buñuel (1900-1983) recorda o lançamento, em Paris, em 28 de outubro de 1930, de $A$ idade do ouro (L'âge d'or), que dirigiu e cujo roteiro, baseado em romance do Marquês de Sade, foi escrito por ele e por Salvador Dalí (1904-1989):

O filme estreou, como Un chien andalou [Um cão andaluz], no Studio 28, e foi apresentado durante seis dias com salas cheias. Após o que, enquanto a imprensa de direita desancava o filme, os Camelots du $\mathrm{Roi}^{8}$ e as Jeunesses Patriotiques ${ }^{9}$ atacaram o cinema, laceraram os quadros da exposição surrealista localizada na entrada, quebraram as poltronas, jogaram bombas na tela. Foi o "escândalo de L'âge d'or".

Uma semana depois, sob pretexto de manutenção da ordem, o chefe de polícia, Chiappe, pura e simplesmente proibiu o filme. Proibição que se manteve durante cinquenta anos. Só era possível ver o filme em exibição privada ou em cinematecas (BUÑUEL, 1982, p. 162).

Entre as diversas reações conservadoras geradas por essa crescente relevância social, a mais importante, no terreno da produção, deu origem nos EUA a um acordo de autorregulamentação dos grandes estúdios, o Código de Produção ou Código Hays, assim batizado informalmente por ter sido criado no Hays Office, secretaria da Motion

\footnotetext{
${ }^{8}$ Organização de jovens integralistas franceses, criada em 1908.

${ }^{9}$ Movimento nacionalista francês de inspiração bonapartista, criado em 1924.
} 
Picture Producers and Distributors of America (MPPDA) ${ }^{10}$ que recebeu o nome de seu primeiro presidente, Will Hays (1879-1954). Encomendado em 1930 a um padre jesuíta e a um editor católico, o código tinha a função de controlar o conteúdo dos filmes, e a equipe encarregada de zelar por seu cumprimento agia nas esferas de préprodução (trabalhando sobre o roteiro de cada filme) e de pósprodução (avaliando o corte final) (SCHATZ, 1991, p. 177).

O escritor alemão Joseph Roth (1894-1939) detectou o estado de ânimo em relação aos supostos efeitos amorais do cinema em texto ambíguo, publicado em 1934, que se refere a filmes como obra do "Anticristo", sem que fique claro se o autor compactua com esse juízo ou se, ao contrário, o ironiza. Roth lembra seu "primeiro encontro com o Anticristo", quando era menino e o "milagre das sombras vivas" foi até ele. Segue-se, no texto, a descrição de sessão realizada sob uma lona - com observações sobre o comportamento do público, o barulho do projetor, a luz incidindo sobre a tela - e de cenas dos filmes então projetados, como a de uma princesa egípcia que "se banhava nua, no Nilo, com súditas também nuas" e a de "regimentos inteiros" em batalha entre Rússia e Japão:

O pavor que tomou conta de nós resultava do fato de que pessoas, sem o hábito das pessoas de hoje em ver as sombras vivas sem corpos vivos, ficavam sem saber por instantes se não eram essas as sombras de soldados mortos que avançavam sobre nós. [...] 0 pretenso milagre técnico que simplesmente nos apavorava ou que nos enchia de orgulho com nossos progressos difere do verdadeiro milagre que nos eleva e nos enche de fervorosa alegria. Pois sabíamos que isso só se realizaria pelas "coisas naturais". [...] 0 homem que povoava o

\footnotetext{
${ }^{10}$ Hoje, Motion Picture Association of America (MPAA), espécie de sindicato patronal que defende os interesses das grandes produtoras e distribuidoras norte-americanas, nos EUA e no exterior.
} 
cinema com essas sombras não poderia ser punido [...] porque ele sabia que éramos seres humanos, pois nos oferecia prazeres carnais e favores mortais. E contava com a nossa volúpia (In PRIEUR, op. cit., p. 173-177).

Registre-se que a desconfiança - sobretudo entre grupos religiosos de matiz mais conservador - de que o cinema era algo demoníaco, simplesmente por reproduzir o movimento do mundo natural, vinha desde o final do século XIX, como ilustra episódio relatado por Paul Decorps, cinegrafista enviado pelos irmãos Lumière para a captação de imagens na Rússia, e que aproveitava para promover sessões de filmes durante a jornada. Em Nijni Novgorod, ele supôs que havia algo de estranho com os espectadores, pelo comportamento deles na saída, e trancou-se com seus colegas de viagem na barraca que servira como sala de projeção. Logo, "golpes violentos sacudiram a porta", seguidos por um grito: "Satã! Satã!". A polícia impediu que a equipe de Decorps fosse agredida, mas não evitou que a multidão incendiasse a barraca e com ela o cinematógrafo, o instrumento do mal. "Ao fogo os feiticeiros!", diziam (RITTAUD-HUTINET, 1995, p. 332-333).

\subsection{O cinema é necessário à educação: uma proposta conservadora}

Não consta que o advogado brasileiro Joaquim Canuto Mendes de Almeida partilhasse de visão assim obscurantista do cinema a ponto de bradar "Satã!" contra a produção industrial da virada dos anos 1920 para os anos 1930, mas seu livro Cinema contra cinema: bases gerais para um esboço de organização do Cinema Educativo no Brasil, publicado em 1931, quando o autor era promotor público em Tatuí 
$(\mathrm{SP})^{11}$, corresponde a uma resposta de viés reacionário à capacidade de o cinema - essa bênção fascinante graças à qual Masino, o personagem de Pavese, aprendia a viver - "ensinar" usos e costumes (nem sempre desejáveis para uma sociedade "sadia", na visão do autor) às suas plateias, principalmente as compostas por crianças e jovens.

O livro não deixava nenhuma dúvida sobre a simpatia de Almeida pelo integralismo. Ele considerava os alemães "intelectual e moralmente" superiores "aos nossos sertanejos", devido a "circunstâncias plásticas que esculpem o homem"; preferia que um "sentimento de revolta ou desagrado" levasse um japonês ao suicídio ritualístico, o hara-kiri, do que um brasileiro ao "empastelamento popular de algum consulado estrangeiro" (ALMEIDA, 1931, p. 140). No primeiro ato, Almeida parece ver grandeza moral; no segundo, pequenez. Teria aprendido, também ele, a pensar assim com o cinema? Ou a pensar assim apesar do que o cinema the ensinava?

"O máximo problema nacional é a educação", afirma Almeida (op. cit., p. 201). Referia-se, naquele momento, a dois aspectos distintos do termo: a educação formal, obrigação do Estado cumprida em estabelecimentos mantidos exclusivamente para essa finalidade, de acordo com a legislação escolar em vigor; e a educação dos cidadãos consumada no cotidiano por meio das demais instituições sociais, como a família, e sujeita ao impacto, entre outros, dos meios de comunicação de massa.

\footnotetext{
${ }^{11}$ Antes, Almeida havia se envolvido com a produção e a crítica cinematográfica. Posteriormente, foi promotor público na Capital e, em 1935, tornou-se livre-docente da Faculdade de Direito da Universidade de São Paulo, pela qual se aposentou. Trabalhou ainda como assessor da Secretaria de Governo do Estado de São Paulo e da missão brasileira na Organização das Nações Unidas, foi procurador-geral da República durante o governo Jânio Quadros e escreveu diversas obras jurídicas. Cf. SALIBA, 2003.
} 
Suas ideias a respeito de como o cinema deveria assumir papel educativo, em ambas as dimensões, são articuladas no livro com base em raciocínio que caracteriza emergência - mais do que útil, o cinema “é, hoje, necessário à educação", diz (ALMEIDA, op. cit., p. 13) - e que termina com a proposta detalhada de criação de um órgão estatal, o Instituto Nacional de Cinema Educativo ${ }^{12}$. Almeida não era o único, naquele momento, a atribuir à união entre os dois campos um papel social determinante para a "saúde moral", a "construção" e a “regeneração" (ALMEIDA, op. cit., p. 5). Em 1930, Jonathas Serrano e Francisco Venancio Filho haviam publicado o livro Cinema e educação ${ }^{13}$. Ambos, em companhia do próprio Almeida e de José de Oliveira Orlandi e Galaor Nazareth de Araújo, escreveram artigos para edição especial da revista Escola Nova que tratava, em julho de 1931, do "cinema na escola", e cuja seção bibliográfica inclui "coleção de artigos diversos sobre o assunto" publicados no Rio de Janeiro, de 1916 a 1918, por Venerando da Graça ${ }^{14}$.

Subdiretor técnico de Instrução do Distrito Federal, Serrano era responsável por organizar as ainda incipientes atividades determinadas pela reforma do ensino que, por meio do art. 296 do Decreto 3.821, de 23 de janeiro de 1928, obrigava "todas as escolas de ensino primário, normal, doméstico e profissional" a manter "salas destinadas à instalação de aparelhos de projeção fixa e animada, para fins meramente educativos" (ALMEIDA, op. cit., p. 208). Além de refletir,

\footnotetext{
12 Criação de Edgard Roquette-Pinto (1884-1954), o Instituto Nacional de Cinema Educativo (INCE) foi instituído em 1937, por meio da Lei $n^{\circ} 378$, art. 40, no âmbito do Ministério da Educação e Saúde. Já em 1936, no entanto, uma comissão instaladora foi responsável pela produção de 26 filmes de caráter educativo, aquisição de títulos e respectiva distribuição à rede de ensino. Em 1966, por meio do Decreto-lei $n^{\circ} 43$, art. 31 , o INCE foi incorporado ao Instituto Nacional de Cinema (INC). Cf. RAMOS e MIRANDA, 1997, p. 298-299.

13 São Paulo: Melhoramentos, 1930.

${ }^{14}$ Cf. MORETTIN, 2001, p. 128-141.
} 
em sintonia com o que ocorria no mesmo sentido em países da Europa e nos EUA, tomada de consciência quanto à penetração do cinema como espetáculo de massas e de seu poder de influência sobre as plateias, especialmente as infanto-juvenis, esse movimento se inseria no cenário de transformações pelas quais passava o sistema educacional brasileiro, com destaque, no caso de Almeida, para as mudanças em curso no Estado de São Paulo. Como em diversas outras ocasiões na história do País, acreditava-se que o investimento em educação seria prioritário para o desenvolvimento nacional e lutava-se publicamente por isso.

A partir de 1930, a educação paulista, sobretudo na capital, sofrera profundas mudanças, com "a integração definitiva da escola na paisagem urbana e, consequentemente, sua inserção na vida cotidiana de toda a população":

Houve, nesse período, o desenvolvimento de dois movimentos paralelos e complementares: o aumento crescente relativo das matrículas nos vários níveis de ensino e a gradual eliminação dos antigos diferentes tipos de ensino de nível secundário criados na fase anterior, e dos vários entraves que foram se interpondo a eles. [...]

A elite intelectual paulista atuou para criar condições para a "modernização" do país e para a renovação da educação. Na década de 1930, vários mecanismos foram tentados, debatidos, experimentados, postos em execução. Congressos de educação, revistas pedagógicas, conferências, aprimoramento da estatística escolar, implantação dos setores "auxiliares" do ensino (cinema educativo, orfeão infantil, escola de educação física, bibliotecas infantis nos Grupos Escolares, assistência ao aluno carente, merenda escolar e tantos outros) (MARCílIO, 2005, p. 235236). 
Articuladas por representantes dos grupos sociais que apoiavam as pressões da fração industrial pela modernização do País, as propostas educacionais em circulação no Estado de São Paulo se consolidariam com o lançamento, em 1932, do "Manifesto dos Pioneiros da Educação Nova", redigido por Fernando de Azevedo e assinado por 26 educadores brasileiros. Na hierarquia dos problemas nacionais, dizia o texto, nenhum "sobreleva em importância e gravidade ao da educação. Nem mesmo os de caráter econômico lhe podem disputar a primazia nos planos de reconstrução nacional". 0 manifesto procurava instalar a criança no centro de toda a ação pedagógica e pregava atuação mais concreta e firme do Estado, requerendo por isso maior força para a escola pública. Outros pontos importantes do manifesto eram a laicidade, a gratuidade e a obrigatoriedade do ensino público (MARCÍLIO, op. cit., p. 237).

Esses princípios já eram abraçados por Almeida em sua proposta de incorporação do cinema pelo sistema escolar, que se orientava pela crença na eficácia dos filmes como "instrumento pedagógico universal". Pequena parte de seu livro, entretanto, será efetivamente dedicada ao tema: cerca de 60 páginas, em um total de 210, correspondentes ao capítulo 2, "Cinema educativo", que integra a quarta parte, "Aspectos morais" (sem contar as sete páginas do Apêndice, com "Realizações da Diretoria Geral do Ensino de São Paulo").

"O cinema escolar muito poderá fazer para contrabalançar os maus efeitos do cinema comum", afirma Lourenço Filho ${ }^{15}$ no prefácio do livro de Almeida, antecipando a oposição entre o que o autor chama de "cinema mercantil" (o "comum") e o "cinema educativo" (o "escolar"). O prefaciador também é feliz, no sentido de resumir a obra,

${ }^{15}$ Autor de Introdução ao estudo da Escola Nova, s/d. 
ao encerrar seu texto com uma citação: "Não errou Luciano de Féo, quando disse que 'o cinematógrafo é, hoje, um dos grandes problemas sociais, a que todos devem dar atenção' ".

Lourenço Filho acerta, portanto, ao escancarar que Almeida associa, no livro, a causa do cinema "educativo" à condenação do produto que então ocupava, e continua a ocupar até hoje, as salas comerciais de exibição. A rigor, não seria preciso que houvesse, no título e no corpo do trabalho, a proposta de certo cinema contraposto a outro: o ponto central de sua argumentação caberia em um livro que se chamasse apenas "Contra o cinema mercantil", tendo em vista que seu interesse primordial é o de qualificar negativamente os filmes que se tornam "objeto de comércio" graças a homens que visam a "lucros financeiros" com eles (ALMEIDA, op. cit., p. 7-20).

$\mathrm{Na}$ primeira parte do livro, Almeida apresenta definição etimológica da palavra "cinema" e resume os conteúdos das partes que se seguem. Na segunda, com o provável intuito de suprir carência bibliográfica no Brasil, discorre sobre o que chama de "aspectos materiais", reconstituindo os avanços tecnológicos que permitiram à humanidade criar a ilusão da projeção de imagens em movimento, o que levou ao cinema silencioso e, depois, ao sonoro. Imagens ilustrativas de aparelhos e de processos de captação e de exibição acompanham os capítulos.

Assim, o autor acaba por fazer espécie de breve introdução à história do cinema, ainda que prefira apresentá-la com nomenclatura diferente. Ao final dessa parte, antecipa com dose razoável de acuidade uma drástica alteração no cenário dos meios de comunicação de massa, ao lembrar o surgimento da televisão - "realidade palpitante, em franco aperfeiçoamento e prestes a ampla vulgarização" - que viria a transformar "o aspecto dos espetáculos cinematográficos", com 
projeção "mediante irradiação, em telas receptoras do mundo inteiro" (ALMEIDA, op. cit., p. 76). Pode-se considerar que Almeida, tão conservador em seu juízo moral, adota raciocínio progressista ao identificar que a televisão seria apenas novo veículo para o que o cinema já proporcionava; sem utilizar o termo audiovisual, compreendia que o aparelho doméstico de exibição de imagens e sons se juntava ao cinema para constituir universo integrado e complementar.

Embora recomende não esquecer a novidade, que apenas começava a se desenvolver no Reino Unido e nos EUA, o próprio Almeida a deixará de lado no restante do livro, projetando um cenário do qual ela não faria parte, o que compromete boa parte de seu raciocínio: a contraposição de um cinema "educativo" - de circulação intensiva na escola, mas não só ali - ao "mercantil" seria inócua diante da presença constante, nas casas de crianças e jovens, de um meio de comunicação que Almeida talvez considerasse, tomando por base o que aponta nos filmes exibidos em salas comerciais, ainda mais "mercantil" do que o Anticristo de Roth ${ }^{16}$.

$\mathrm{Na}$ terceira parte, os "aspectos intelectuais" do cinema são examinados. Ali, Almeida se entusiasma, ao falar do "cinema documental", com a capacidade de os filmes oferecerem ao homem o que até então era exclusividade de outros meios:

O transporte é o meio natural de apresentação direta dos objetos da realidade aos sentidos humanos. Põe a imagem real defronte do homem ou leva o homem aonde se encontra a imagem real.

\footnotetext{
16 Pelo que se verá, no entanto, um expediente que o autor considerava apropriado para o cinema se encarregaria eventualmente de resolver os supostos problemas morais e comportamentais que a televisão traria: a censura, exercida pelo Estado, classificando programas como impróprios para determinadas faixas etárias e horários de programação, ou mesmo proibindo sua exibição.
} 
O cinema, nesse mister, substitui quaisquer instrumentos de transporte terrestre, marítimo, fluvial, aéreo ou submarino.

O que o olho da objetiva vê, em qualquer parte, a película grava, para contar, mais tarde, pela projeção luminosa, numa exatidão e numa clareza de figura capazes de fazer inveja à própria realidade como muita gente a percebe. Tudo que o homem pode ver viajando, pode ver também no cinema. $E$ talvez melhor, porque mais bem ordenado (ALMEIDA, op. cit., p. 82).

Almeida não parece atentar ao fato de que a ideia de representação do mundo, que atribui em seguida ao "cinema dramático", se aplica também aos documentários. Ao contrário: a menção a ver "melhor" porque as imagens estariam "mais bem ordenadas" em um filme do que na realidade indica grau elevado de inocência em relação à linguagem, talvez incapaz de notar manobras de construção de sentido por meio, por exemplo, dos procedimentos de montagem.

Suas referências de ordem estética parecem ainda presas a conceitos meramente figurativos, quando não positivistas. "Quando o homem concebe a fita bela, forma um ideal artístico em vias de realização, como o faria um pintor", afirma; a "fita que encanta" - bela, perfeita - seria aquela em que estaria "bem medido, enérgico e equilibrado" o uso das "faculdades e potências ativas do cinema" (ALMEIDA, op. cit., p. 87). Chegar ao tópico "cinema dramático" permite que Almeida comece a expor, finalmente e em detalhe, suas reservas. Depois de falar sobre a "arte dramática", tal como se manifesta no teatro, com o uso de tramas e de personagens, ele passa a examinar a manifestação do gênero no cinema. Inicialmente, se apega a características que identifica na então imberbe produção sonora: 
A fita sonora, exigindo deles (atores e atrizes) dotes de voz e de expressão falada, que nem todos possuíam e para que nenhum se achava educado, dispensou-os em grande número ou rebaixou-os a plano inferior. Os claros abertos começaram a ser preenchidos com artistas do tablado. Estes, embora não possuindo a educação adequada para falar ao microfone, tinham a cultura da expressão falada suficiente às primeiras exigências do estúdio. À vista do que, passaram-se para - cinema falado também seus diretores de cena, autores teatrais e auxiliares do palco, trazendo para as fitas uma respeitável bagagem de preconceitos e regras da arte abandonada. A reação dos elementos remanescentes da Scena Muda foi impotente para contê-los de chofre. Por isso, a maioria da produção falada do cinema tem sido defeituosa, eivada de vícios e defeitos que, no palco, são regra, recurso artístico, [...], mas, na tela, servida pelo extraordinário poder de movimento e até de ubiqüidade da objetiva de filmar, denunciam péssimo gosto e resultam em desagradáveis efeitos estéticos (ALMEIDA, op. cit., p. 123).

Expressões utilizadas por Almeida - como "regras", "defeituosa", "péssimo gosto", "desagradáveis" - já denunciam postura moralista, que se estenderá, mais tarde, à análise de conteúdo dos tais filmes "mercantis". Ela se combina, de qualquer forma, a um entendimento grandiloquente das possibilidades estéticas do cinema, alinhado com o pensamento que o considerava a sétima e maior das artes desde a publicação de manifesto de Canudo: "excede o Teatro, por tudo, na representação da vida", ao reproduzir "todos os ambientes externos e internos de um romance"; faz com que o espectador seja locomovido "em todas as direções e distâncias do ambiente dramático"; e dispensaria o "trabalho psicológico de análise" exigido pelo teatro, trabalho esse que seria "já previamente feito pelo olho da objetiva".

Grupos de "regras do cinema", argumenta o autor, derivam dessas e de outras "contingências": imaginar o drama "com cenas bonitas à fotografia aliada à fonografia", no caso da "fita sonora"; 
"ambientar, livremente, as cenas do enredo", que devem se passar "nos seus mais bonitos ambientes naturais sem outras preocupações que não sejam o livre movimento dos personagens e acontecimentos em quaisquer cenários imagináveis". Assim, deve-se "fazer a cena evoluir, livremente, no ambiente, em todas as direções e a todas as distâncias, para atingir, em cada quadro, apenas o que parece necessário à compreensão e à beleza". Para Almeida, "não é bonito que, no quadro fotográfico, apareçam elementos intrusos que não interessam, antes atrapalham, a passagem da cena que se representa", pois "cada quadro deve conter apenas o essencial ao relato do lance que exprime"17 (ALMEIDA, op. cit., p. 126).

$\mathrm{Na}$ quarta parte, dedicada aos "aspectos morais", o autor permite que se identifiquem proximidades entre suas ideias sobre cinema e sobre educação, e o pensamento conservador daquele período histórico. Ao mesmo tempo em que manifesta a já mencionada perspectiva obtusa dos "contrastes" entre povos, Almeida é capaz de se antecipar ao pensamento inovador na educação - fruto, provavelmente, das circunstâncias de ordem escolar que o cercavam naquele momento em São Paulo, preconizando uma drástica reforma no sistema de ensino do País - e, décadas antes da disseminação dos conceitos pedagógicos de Paulo Freire, defender que

os educadores não se podem encastelar no âmbito da escola, indiferentes ao que se desdobra lá fora; devem, antes, ter permanentemente diante dos olhos, a consideração das forças psicológicas que surgem, crescem e agem, espontânea e inconscientemente, na sociedade, em colaboração ou em detrimento da obra escolar. Sua missão, em face dos modernos postulados

\footnotetext{
17 Tais apreciações de Almeida lembram a tese do documentário Arquitetura da destruição (Undergangens arkitektur, 1989), de Peter Cohen, em que o nazismo é analisado como projeto estético de embelezamento do mundo.
} 
de pedagogia, se resume em reforçar e sistematizar, para o sentido educativo, a ação dessas forças psicológicas exteriores. Nunca obstruí-las, retorcê-las, opor-lhes diques, capazes, antes, de provocar grandes inundações do que de dominá-las e sempre em desperdício de energia que as correntes impetuosas, devidamente canalizadas, podem produzir (ALMEIDA, op. cit., p. 143).

De acordo com Almeida, o cinema educativo, para estar de acordo com os modernos princípios pedagógicos, deve "colaborar na obra de integração da escola na ação geral educativa de cada comunidade". É evidente que a relação com as ideias que Freire viria a articular se dá apenas no terreno da metodologia (a do aproveitamento das circunstâncias sociais do aluno no contexto escolar), e não dos fins: não é a transformação social que Almeida prega, mas a manutenção do status quo por meio de uma educação que faça "um indivíduo, um grupo, uma geração" tomar "os contornos dos vasos que os contêm" - ação "plástica" que parte de uma "vontade inteligente que sabe o que quer afinal e que se orienta de acordo com uma série de normas, de eficácia mais ou menos comprovada" (ALMEIDA, op. cit., p. 139-141).

Persiste, nesse ponto do volume, a argumentação enfática a favor do uso do cinema, associada a uma proposta de reforma radical nos processos de ensino e aprendizagem, bem como à condenação do "mercantilismo". O século "é do cinema" e o educador "não pode desprezá-lo". Ao contrário: deve "introduzi-lo na escola, modificando processos e métodos de educação", e deve também - o educador ainda, frise-se - "introduzir a educação no cinema, para orientá-lo e desviá-lo dos desacertados atalhos a que o levam os interesses mercantis do capitalismo mundial" (ALMEIDA, op. cit., p. 143-144). 
É pedagógico, pois, seu entendimento do que pode o cinema - e, na sua avaliação, podia então mais do que instituições como a própria escola ou a família. Estaríamos, segundo a sua linha de raciocínio, diante de instância quase milagrosa, a operar instantâneas e profundas transformações no espectador:

A força física do cinema é observável nas modificações psicológicas, fisiológicas e patológicas que uma fita pode produzir no homem. Findo o espetáculo, o espectador adquiriu um progresso intelectual, correspondente às novas noções das coisas que acaba de conhecer pela tela, e, dominado pela excitação de ânimo que as cenas lhe infundiram, está pronto para seguir pela imitação a moralidade da fita. Na primeira oportunidade em que surja à frente desse indivíduo uma situação que se assemelhe, mesmo remotamente, à da tela, há de lhe ocorrer, consciente ou inconscientemente, a respectiva solução cinematográfica, como uma que já viu, ao menos uma vez na vida, dar bom resultado. Assim os exemplos do cinema frutificam (ALMEIDA, op. cit., p. 147).

Sobre as crianças, o efeito seria ainda maior. Ao falar desse tópico, Almeida adota postura nacionalista que se integra ao pensamento do período. A criança de então não teria mais medo do "cuca" e do "papão" porque "não há quem possa simplesmente por palavras" Ihe sugerir figuras mais terríveis ou situações mais perigosas "do que as que viu nítidas, com os próprios olhos, na tela de projeção"; dessa forma, "o menino tem menos entusiasmo ante o pavilhão nacional do que em frente às bandeiras que aparecem nas fitas", ligadas a grandes batalhas ou gestos de bravura, enquanto o "pendão auriverde" estaria acompanhado apenas por "bocejante e inexpressiva oração cívica". 
Daí para a defesa de censura mais rígida do que a então praticada configura-se um passo curto, que o autor dá com rapidez e desenvoltura, sem constrangimentos, pois "o Cinema é tão forte que já corrompeu - se é que é adequada a expressão - os próprios censores, modificando-os mais do que eles às fitas e adaptando-os, assim, às liberdades da tela". Ao Estado, julga Almeida, "não bastará assumir o papel negativo de censor dessa produção [mercantil]. Ser-lhe-á útil e quase sempre necessário agir de maneira positiva, transformando-se em produtor" (ALMEIDA, op. cit., pp. 149-153).

Os funcionários da censura deveriam ser perfeitos técnicos de cinema e de educação, agindo sob o influxo direto da secretaria da Educação ou de órgãos coletivos educadores e permanentemente em contato com os problemas educacionais. Para que não se vissem eles próprios transformados pelo cinema antes de o conseguirem modificar. $O$ que é, aliás, freqüente quando a seção de censura não é organizada em bases científicas e psicológicas bem firmes e aos censores se impõe exclusivamente o mister diário de ver fitas desde o raiar do dia até o aperitivo do jantar. [...] Ao cabo de algum tempo, em vez das fitas estarem bem educadas é a Censura que se acha mal educada... (ALMEIDA, op. cit., p. 165).

As atividades dessa censura de atuação ampliada seriam incorporadas por um "órgão técnico de produção cinematográfica", que serviria "não apenas à parte positiva da penetração da educação no Cinema", mas ainda ao movimento escolar de "penetração do cinema na Educação: seria o centro de escolha e esboço, plano e filmagem, classificação e distribuição das fitas pedagógicas e não pedagógicas". O modelo preconizado por Almeida, não obstante as diferenças de caráter político entre o Brasil e a URSS, é o soviético, que 
"pretende resolver o problema da sujeição absoluta do cinema à Educação". Naquele país, observa o autor,

\begin{abstract}
consideram-se educativas todas as fitas escolares ou extra-escolares que respondam a objetivos de ensino ou de educação generalizada, desde que se enquadrem num plano temático anual do Comitê Central de Controle do Repertório do Comissariado da Instrução Pública. Esse plano fixa a ordem e a proporção das fitas suscetíveis de comover, divertir ou instruir, sujeitas sempre a finalidades educativas (ALMEIDA, op. cit., p. 155-157).
\end{abstract}

A proposta implica, como se nota, adoção de modelo rigoroso de censura à exibição. Seria, de acordo com Almeida, uma "intervenção indireta" que lograria, "pelos cortes da censura na fita filmada, livrá-la de vícios nocivos à educação, revelando, em cada caso novo, aquilo que o cinema não deve divulgar; é seu aspecto negativo". Depois de acender uma vela para Lênin (ou, naquela altura, a Stálin), o autor acende outra para o Papa, ao destacar que a Igreja Católica, "grande força internacional", "vem realizando congressos de cinematografia e cada vez mais se esforça, com seu prestígio moral, para purificar os temas das fitas mercantis". Entre as conclusões do $2^{\circ}$ Congresso Católico Internacional do Cinema, realizado em Munique (Alemanha) de 17 a 19 de junho de 1929, presentes "o núncio do Papa, o bispo auxiliar da cidade, além de outros prelados, clero e católicos do mundo", Almeida destaca o reconhecimento da "necessidade da censura oficial", pedindo que "sejam proscritos os filmes contra a religião e contra a moral e que os católicos sejam representados nas comissões de censura", e rogando "particular cuidado à proteção da infância e da juventude" (ALMEIDA, op. cit., p. 177). 
Em São Paulo, os poderes públicos têm sabiamente olhado com simpatia a iniciativa, que ora desponta, da Associação Brasileira de Cultura em favor do cinema infantil. A organização de filmes e de espetáculos adequados é finalidade da benemérita cruzada. Contribuirá eficazmente, para a implantação dos princípios básicos da higiene mental infantil (ALMEIDA, op. cit., p. 209).

O ideal para a execução dessas políticas de "higienização mental", sustenta Almeida, seria um Instituto Nacional de Cinema Educativo (INCE):

Essa organização, de caráter permanente, dotada dos elementos materiais e pessoais técnicos necessários, incumbir-se-ia de adquirir, aqui ou no estrangeiro, e filmar as fitas pedagógicas ou não pedagógicas necessárias e úteis à sistematização, nas escolas, do ensino pelo cinema, e à divulgação, regulada oficialmente, em todas as telas do país, das "fitas do governo", de caráter educativo em geral. Tal a sua ação positiva.

Os serviços de censura ao cinema mercantil constituiriam sua atividade negativa.

O cinema oficial, além de prestar ótimos serviços à educação, serviria - como hoje a imprensa oficial - a interesses palpitantes das nossas repartições públicas.

Só um instituto desse gênero e com tais finalidades nos dará, além da censura educativa criteriosa, boas fitas de ensino. $E$, ante milhares de telas em funcionamento em todo o país, não dormirão mais esquecidos nos arquivos das repartições públicas os rolos de celulóide que tanto dinheiro custaram ao Tesouro. Porque o governo terá, aí, os meios positivos para a divulgação do cinema oficial. Tanto os meios materiais, como os psicológicos: a fita educativa há de ser, tecnicamente, perfeita.

O Instituto Nacional de Cinema Educativo é o ideal a atingir. Se os poderes públicos não podem, de um momento para outro, torná-lo completa realidade, devem acoroçoar com um apoio franco e decidido, as pequeninas iniciativas particulares que se reajustam, 
esparsamente, às diversas funções e finalidades elementares do projetado instituto. E, quando este aparecer, virá como órgão centralizador e coordenador dos núcleos de atividade existentes, rompendo, de vez, quaisquer contradições que estes apresentem (ALMEIDA, op. cit., p. 205-206).

Seis anos depois da publicação de Cinema contra cinema, com a instituição do INCE, algumas das missões relacionadas por Almeida se incorporaram à pauta de atuação do organismo estatal, sobretudo no que diz respeito à produção ${ }^{18}$. Jamais seria, no entanto, o "órgão centralizador e coordenador" que romperia com as contradições das atividades relacionadas a cinema e educação, quadro que se mantém inalterado na política audiovisual do País até hoje.

Dialogar com as ambiguidades expostas pelas posições de Almeida - ora extremamente reacionárias, ora surpreendentemente progressistas - possibilita localizar na década de 1930 as matrizes de ideias que ainda hoje são referenciais para se refletir sobre as conexões entre o audiovisual e a educação; e, consequentemente, para que se reflita também sobre horizontes de conteúdo para a qualificação de professores nessa área, a saber:

a) a crença de que as imagens em movimento têm uma capacidade de sedução e convencimento de corações e mentes (parafraseando aqui o título do célebre documentário de Peter Davis sobre a Guerra do Vietnã ${ }^{19}$ ) que supera (e confronta) a das outras instâncias educacionais da sociedade, inclusive a responsável pela educação formal, a escola. A partir desse conceito, que superestima o

\footnotetext{
${ }^{18}$ Cf. MORETTIN, 1994.

${ }^{19}$ Corações e mentes (Hearts and minds, 1974), uma das obras determinantes, no domínio do audiovisual, para que se alterasse nos EUA a percepção popular sobre a presença de tropas norte-americanas no Sudeste Asiático.
} 
audiovisual ao caracterizá-lo como instrumento de poderes quase ilimitados, a argumentação de Almeida desenvolve, de um lado, a esperança de que, sob certas condições, ele possa representar panaceia a atuar "a favor" (do que, o idealismo de plantão dirá); e, de outro, alimenta o receio de que, sem controle, ele atue "contra" (o que o idealismo de plantão estiver pregando). Não se pode perder de vista na discussão desse tema, contudo, que os determinantes na equação sobre os poderes de persuasão do audiovisual - tema a ser tratado com maior complexidade do que na abordagem de Almeida - têm mais a ver com os processos segundo os quais ele dialoga com a Educação Básica, em aspectos bem concretos do cotidiano escolar, e que passam pela capacidade de mediação do educador;

b) a suposição de que o Estado precisa atuar diretamente para regular as condições em que o audiovisual pode exercer seu caráter educacional. Essa interferência se daria em ao menos duas áreas: na de produção, gerando material compatível com os objetivos de "higienização"; e na de censura, vetando o que representasse "perigo". A política de intervencionismo estatal sugerida por Almeida encontra respaldo ainda hoje, em políticas de uso do audiovisual na educação que passam, por exemplo, pela formação de acervos para uso escolar a partir de critérios adotados no topo da hierarquia educacional, com o objetivo, explícito ou implícito, de estabelecer linhas sobre o que cabe e o que não cabe em salas de aula;

c) a resistência ao "cinema mercantil", como se toda a produção inserida na lógica da economia do audiovisual fosse desprovida de valor ou interesse. Ao propor esse descarte, Almeida caminha, de forma paternalista, em direção contrária à das estratégias de alfabetização midiática. Atitude mais democrática é a de investir na criação de instrumentos que permitam a crianças e jovens discernir na produção 
audiovisual, por conta própria, o que Ihes pareça joio e o que thes pareça trigo. Além disso, mesmo a estratégia de denúncia da "mercantilização" encontrará, na análise de obras com essas supostas características, a mais eficiente maneira de expor seus mecanismos de persuasão.

\subsection{O cinema e a TV são necessários à educação: uma proposta} transformadora

Em relação ao entusiasmo pelas possibilidades do audiovisual na formação de crianças e jovens, e também na avaliação crítica do que era oferecido a elas pelo cinema "mercantil" e pelos meios de comunicação de massa, respectivamente, Almeida se aproxima muito do tom com que seriam apresentadas décadas depois, pelo cineasta italiano Roberto Rossellini (1906-1977), ideias de matriz também utópica sobre audiovisual e educação. Essa aparente fraternidade entre o pensamento de ambos, contudo, é desfeita quando se observam a ação e os resultados que imaginam a partir dessa conexão: enquanto a abordagem autoritária do primeiro preconiza o controle - do Estado, das autoridades escolares, dos educadores - sobre a produção a que teria acesso o público infanto-juvenil, em tutela de caráter positivista, o segundo defende, com inspiração marxista, uma atitude iluminista.

As reverberações do neorrealismo italiano - movimento cinematográfico desencadeado na Itália, ainda durante a II Guerra Mundial, e que se tornou conhecido em outros países a partir do final do conflito - são notáveis em boa parte da produção audiovisual contemporânea. No domínio de caráter mais autoral, sua tradição é facilmente reconhecível nos "cinemas novos" dos anos 1960, como a Nouvelle Vague ("nova onda") francesa e o Cinema Novo brasileiro, 
bem como no novo realismo iraniano dos anos 1990, representado em especial pela obra de Abbas Kiarostami ${ }^{20}$, Mohsen Makhmalbaf ${ }^{21}$ e Jafar Panahi ${ }^{22}$, e no cinema independente chinês da virada do milênio, cujo principal realizador é Jia Zhang-ke ${ }^{23}$.

O impacto do neorrealismo também se faz notar na produção industrial norte-americana, que precisou assimilar algumas de suas características - como a predileção pelos pequenos dramas do homem comum, pelo uso de locações e de atores não-profissionais - diante do novo patamar de verossimilhança estabelecido, para a ficção no cinema, pelo movimento italiano e pelos herdeiros de sua tradição. É sintomático que alguns dos expoentes do processo de revitalização da indústria norte-americana no período que vai do final dos anos 1960 ao início dos 1980 (a "nova Hollywood"), cineastas como Martin Scorsese $^{24}$ e Francis Ford Coppola ${ }^{25}$, tenham reconhecido a influência do cinema italiano do pós-guerra em sua formação cultural e mesmo em seu desejo de realizar filmes profissionalmente ${ }^{26}$.

\footnotetext{
20 Diretor de Onde fica a casa do meu amigo? (Khane-ye doust kodjast?, 1987) e Gosto de cereja (Ta'm e guilass, 1997), entre outros longas-metragens.

21 Diretor de Salve o cinema (Salaam cinema, 1995) e Um instante de inocência (Nun va goldoon, 1996), entre outros longas-metragens.

22 Diretor de O balão branco (Badkonake sefid, 1995) e O círculo (Dayereh, 2000), entre outros longas-metragens. Detido pelo governo iraniano em março de 2010, ele passou oito meses no cárcere e fez greve de fome, gerando ampla campanha internacional de solidariedade; em dezembro, uma corte iraniana o sentenciou a seis anos de prisão, e o proibiu de fazer filmes e viajar para o exterior por um período de 20 anos.

${ }^{23}$ Diretor de Plataforma (Zhantai, 2000) e Em busca da vida (Sanxia haoren, 2006), entre outros longas-metragens.

${ }^{24}$ Diretor de Taxi driver (id., 1976) e Touro indomável (Raging bull, 1980), entre outros longas-metragens.

25 Diretor de $O$ poderoso chefão (The godfather, 1972) e Apocalipse (Apocalypse now, 1979), entre outros longas-metragens.

${ }^{26}$ O documentário Uma década sob a influência ( $A$ decade under the influence, 2003), de Ted Demme e Richard LaGravenese, traz depoimentos desses e de outros cineastas de sua geração sobre a importância da filmografia italiana do pós-guerra em suas carreiras.
} 
De todos os cineastas responsáveis pela deflagração do neorrealismo italiano, Rossellini foi o que desenvolveu trajetória mais peculiar, intensamente associada a uma concepção política do significado das artes e dos meios de comunicação. Depois de iniciar a carreira como diretor na Itália ainda sob o fascismo, seu quarto longametragem, Roma, cidade aberta (Roma, città aperta, 1945), ambientado na capital italiana sob ocupação das tropas nazistas e lançado poucos meses depois do final da II Guerra, foi um poderoso cartão de visitas internacional do movimento. Paisà (id., 1946) e Alemanha ano zero (Germania anno zero, 1948), que completaram a sua "trilogia da guerra", consolidaram o prestígio de Rossellini como um dos responsáveis por um novo modelo de cinema, compromissado com os interesses populares e que se confundia, naquele momento, com as ideias da esquerda italiana, liderada no pós-guerra pelo Partido Comunista Italiano (PCl).

O desenvolvimento de sua carreira viria a inseri-lo, no entanto, em um espectro no qual o humanismo e a influência cristã seriam sobrepostos ao ideário então dominante no âmbito do $\mathrm{PCl}$, no qual diversos profissionais ligados ao neorrealismo militaram, como membros do partido ou simpatizantes. De qualquer forma, pensadores como Karl Marx (1818-1883), Friedrich Engels (1820-1895) e Antonio Gramsci (1891-1937) se mantiveram como referência para suas práticas e reflexões até o final da vida. No cinema, Rossellini realizou ainda filmes como Stromboli (id., 1950), Europa' 51 (id., 1952), Viagem pela Itália (Viaggio in Italia, 1953) e De crápula a herói (II generale della Rovere, 1959). A partir de 1963, preocupado em se dirigir a um público mais amplo do que o representado pelos frequentadores de salas de cinema, passou a realizar obras documentais e ficcionais para a televisão, às quais chamou de 
"didáticas". A essa atividade, combinou a produção de textos sobre os meios de comunicação de massa e a educação ${ }^{27}$.

A dedicação a esses temas, nos últimos 15 anos de carreira, representou o ápice de uma trajetória coerente em direção ao caráter informativo e formativo da obra audiovisual preconizado por Rossellini, e também à tendência para a generalização e a síntese, na análise do cineasta francês François Truffaut (1932-1984), para quem Rossellini deu início à sua obra filmando "unidades pequenas" - um barco de guerra (La nave bianca), uma cidade (Roma, cidade aberta), uma pequena ilha (Stromboli). Em seguida, filmou países (Alemanha ano zero), depois continentes (Europa 51, Índia), e mais tarde "eras da humanidade" ( $A$ idade do ferro, $A$ luta do homem pela sobrevivência) (In GUARNER, 1972).

Reunidas em livro, as reflexões de Rossellini se organizam em três capítulos. O primeiro trata do "nascimento do mundo contemporâneo"; o segundo, da "educação integral"; o terceiro, da "crise da cultura e os meios de comunicação de massas". Os anexos trazem mais três artigos e dois trechos de roteiros para programas didáticos sobre Sócrates e Pascal.

Inicialmente, Rossellini considera que os meios de comunicação representam, na década de 1970, um "espelho do mundo contemporâneo". Ao citar títulos de matérias publicadas em jornais e revistas, bem como situações vistas em filmes e programas de TV, conclui que a predileção por certo tipo de informação - relacionada sobretudo à violência e a apelos eróticos - contribui para "a crescente

\footnotetext{
27 O volume com esses artigos foi publicado na França em 1977, pela Librairie Arthème Fayard (Paris), sob o título Un esprit libre ne doit rien apprendre en esclave (Um espírito livre não deve aprender como escravo, citação de Platão). Todas as citações deste capítulo, em tradução nossa, foram retiradas da tradução em espanhol, Un espíritu libre no debe aprender como esclavo: escritos sobre cine y educación, Barcelona: Paidós, 2001.
} 
desintegração das relações humanas". "Já não é possível o diálogo, a confrontação de teorias opostas", afirma.

A agressividade, "transformada em moda", seria a "manifestação dominante da personalidade". Rossellini lamenta que a pauta dos meios de comunicação de massa não abra espaço a temas de relevância social, como o tráfico de armas. "Ninguém parece mostrar interesse [...] por um grande escândalo, base deste cataclisma social: o tráfico de armas", escreve ${ }^{28}$. Se esse comércio não tivesse adquirido "a difusão que tem atualmente", não teriam chegado "à situação extrema de hoje os conflitos, a repressão, as injustiças e os atos de violência terrorista de que estamos padecendo" (ROSSELLINI, op. cit., p. 31 ).

Essa avaliação negativa da ação dos meios de comunicação de massa encontrará respaldo em Marx para chegar ao conceito de alienação:

Creio estar em condições de afirmar que todas as atividades que hoje chamamos de culturais aumentam a alienação, ou seja, a distância que nos separa de nossa essência humana. Há uma solução para isso? Segundo Karl Marx, a grande meta a perseguir e alcançar é a humanização do homem; em outras palavras, que o ser humano se converta no homem verdadeiro, capaz de expressar as qualidades que lhe são próprias. [...] 0 mundo dos "fetiches" é falso e a história do homem nos mostra, com toda clareza, a inter-relação e a interação incessante de três elementos:

a) o elemento espontâneo (biológico, fisiológico, natural);

b) o elemento reflexivo (a consciência nascente); e

c) o elemento ilusório (o inumano da alienação e dos "fetiches").

\footnotetext{
${ }^{28}$ Rossellini iria gostar de saber que produções industriais recentes, como $O$ senhor das armas (Lord of war, 2005), de Andrew Niccol, e Trama internacional (The international, 2009), de Tom Tykwer, ambos inspirados em fatos verídicos, denunciam as ramificações internacionais do tráfico de armas.
} 
A análise dialética significa o único meio capaz de discernir entre esses elementos, uma vez que se encontram perpetuamente em conflito dentro do movimento real da história (ROSSELLINI, op. cit., p. 32).

Mais tarde, Rossellini recorrerá novamente à "enorme capacidade de análise e de síntese" de Marx para examinar outro conceito, o de revolução do conhecimento. "Disse Marx: 'Religião, ateísmo, humanismo são ideologias, mas a prática revolucionária deve se basear em teorias, ou seja, os conhecimentos científicos da sociedade' ", observa o cineasta. "Uma autêntica revolução" seria possível, apregoa, se "chegarmos a um conhecimento verdadeiro, quer dizer, se nos fizermos completamente inteligentes, adquiríssemos a capacidade de 'ler a essência das coisas' " - ir além, portanto, da ideologia, a "representação que a mente faz das coisas" (ROSSELLINI, op. cit., 37 ).

Rossellini se detém, em seguida, nas "diversas formas do saber" e na "especificidade da espécie humana", bem como na "crise do capitalismo". "Não cabe a menor dúvida de que o sistema capitalista padece de uma crise de extrema gravidade", afirma. Analisar todas as possíveis soluções, "reformistas ou revolucionárias", escaparia ao âmbito do trabalho, segundo ele. Rossellini se compromete, no entanto, a "propor algumas idéias" pelas quais diz ter se tornado obsessivo e que, no seu modo de ver, poderiam "exercer saudáveis efeitos em um domínio fundamental: a educação".

Chega então a hora de propor "uma nova forma de educação", a "educação integral":

Todos os homens políticos, todos os moralistas, todos os idealistas que se propõem sinceramente a levar a cabo transformações sociais, devem ter muito em 
conta uma operação essencial: a de conceber e promover novas formas de instrução, de educação e de cultura. Como se sabe, toda mudança radical pressupõe o desenvolvimento de novos sistemas de pensamento, novos "intelectos", novos "valores", novos modelos culturais com os quais substituir os esquemas tradicionais. É necessário que se plantem, por conseqüência, a instrução, a educação e a cultura em termos inteiramente novos, sem paixão e guiados por um espírito racional: é assim que conseguiremos expressar, com uma clareza absoluta, o que convém pôr em prática para acelerar uma transformação coerente do homem e de um mundo em perpétua evolução (ROSSELLINI, op. cit., p. 37-49).

O conceito de educação integral do qual faz uso foi desenvolvido, segundo Rossellini, de "forma muito paulatina" por diversos pensadores: Engels, Marx, Comenio (1592-1670), LouisAuguste Blanqui (1805-1881), Paul Robin (1837-1912), Francesc Ferrer i Guàrdia (1859-1909), Vladimir Lênin (1854-1924), Thomas Jefferson (1743-1826), Jean Jaurès (1859-1914) e o marquês de Condorcet (1743-1794).

Nesse contexto verdadeiramente revolucionário de reforma do ensino e da escola, que propiciaria formação universal, com base no conhecimento científico acumulado pela humanidade, Rossellini identifica uma forma de atingir o "Éden do conhecimento":

Quando os novos dados são utilizados de imediato pelos pensamentos em vias de elaboração e desenvolvimento, o esforço mental necessário para decifrá-los e memorizá-los resulta mínimo; mas se torna máximo quando esses dados não são utilizáveis, ainda que sejam úteis no sentido absoluto.

Não se pode esquecer isso, se queremos aprender a extrair o devido proveito de todos os gadgets, todos os procedimentos que $\mathrm{o}$ mundo industrial tem produzido com vistas ao consumo e que não têm sido utilizados. 
Eu me refiro aos dispositivos audiovisuais vulgarmente conhecidos com o nome de videocassetes, que a indústria tem lançado em tantas versões distintas e cuja difusão, no entanto, ainda não se generalizou. Esses gadgets são de custo relativamente baixo, fáceis de manejar, e põem ao alcance de qualquer um materiais filmados de diversas espécies. São elementos técnicos pouco volumosos que, utilizados com inteligência, permitiriam acumular um elevado número de informações, facilmente compreensíveis e disponíveis a qualquer momento. Poderiam constituir algo como o Éden da informação, em que cada um seria perfeitamente livre para reunir e saborear quando quiser tudo o que seja necessário para estimular seus pensamentos. Empreguei a palavra "Éden" porque esse domínio deveria se erigir em jardim de dados, de idéias, de pensamentos, de certezas, de provas, de curiosidades e associações cultivadas por todos e à disposição de todos (ROSSELLINI, op. cit., p. 65).

Rossellini acreditava que esses "meios técnicos" permitiriam a todos constatar, com "os próprios olhos", as coisas em seu "aspecto real". Dessa maneira, o que até então era de conhecimento de poucos - as elites com acesso ao imenso volume de informações consolidadas pelo conhecimento científico nos séculos XIX e XX - se tornaria "evidente a todos, e cada um poderia tomar consciência de uma realidade muito mais vasta: o fato de pensar em termos científicos enriquecerá, assim, a mente de todos os seres humanos" (ROSSELLINI, op. cit., p. 66).

Havia 15 anos, ele vinha realizando experiências para "promover uma didática nova por meio da imagem". Essas tentativas tinham o objetivo, segundo ele, de "chegar, concreta e facilmente, à educação integral". Consistiam em uma série de 12 trabalhos já concluídos e a um $13^{\circ}$, sobre Karl Marx, que estava em fase de planejamento quando morreu. 
As obras:

1) A luta do homem pela sobrevivência (La lotta dell'uomo per la sua sopravvivenza, 12 horas).

2) $A$ idade do ferro (La età del ferro, 5 horas).

3) Sócrates (Socrate, 2 horas).

4) 0 Messias (I/ messia, 2 horas e 25 minutos).

5) Os feitos dos apóstolos (Atti degli apostoli, 6 horas).

6) Santo Agostinho (Agostino d'Ippona, 2 horas).

7) A era dos Médici (L'età di Cosimo de Medici, 4 horas e 10 minutos).

8) Blaise Pascal (id., 2 horas).

9) Descartes (Cartesius, 2 horas e 40 minutos).

10) O absolutismo - A ascensão de Luís XIV (La prise de pouvoir par Louis XIV, 1 hora e 35 minutos).

11 ) Viva Itália (Viva I'Italia!, 2 horas).

12) Ano um - O nascimento da democracia italiana (Anno uno, 2 horas).

Essa espécie de videoteca básica sobre a humanidade somava, a essa altura, cerca de 44 horas $^{29}$. Rossellini quis representar esses períodos históricos e esses personagens não porque o haviam "seduzido ou apaixonado", mas porque, no seu modo de ver, "significam articulações fundamentais na história do homem em relação à forma de pensar, de sentir ou de temer, de tomar consciência ou pelo contrário - de refrear toda forma de consciência" (ROSSELLINI, op. cit., p. 67).

${ }^{29}$ Até janeiro de 2011 , haviam sido lançados em DVD no Brasil os títulos de número $3,4,6,8,9,10$ e 12 da lista. 
A série consistia também em um esforço contra a "semicultura" que, de acordo com o cineasta, era produzida pelos meios de comunicação de massa.

Hoje, nos sentimos confusos, arrastados pelas ilusões, alienados como nunca nos havíamos sentido. 0 mal que nos aflige é, talvez, o pior de tantos quantos conhecemos até agora: a semicultura, com a qual todos os meios de comunicação nos bombardeiam.

A semicultura é pior do que a ignorância, porque nos engana. Seu engano torna possível termos atados os pés e as mãos, subjugados por mentiras.

A semicultura, com efeito, é a ilusão de saber.

Os meios de comunicação - imprensa, cinema, rádio, televisão - nos alimentam diariamente com estímulos e notícias. Mas esses meios, não nos esqueçamos, se põem a serviço de grupos dominantes que os manejam; para que os sirvam adequadamente, necessitam de êxito completo.

Assim se explica a tendência atual dos meios de comunicação para o "sensacionalismo", o afã de exagerar as notícias mais insignificantes, de enunciar bombasticamente qualquer tema, qualquer problema, velho ou novo.

Por essa razão, as notícias, problemas e conceitos que difundem estão manipulados desde o princípio. A extrema rapidez com que é preciso que sejam elaborados os meios de comunicação, por outro lado, os condena fatalmente à superficialidade mais absoluta. Os meios de comunicação fazem "cultura" à sua maneira. Mas a servem em doses planas e sem a finalidade de instruir, e sim a de condicionar: o resultado é a semicultura ${ }^{30}$ (ROSSELLINI, op. cit., p. 102).

Embora a imprensa e o rádio também mereçam a atenção de Rossellini nesse diagnóstico contundente, o cinema e a televisão, pela

\footnotetext{
30 No campo do jornalismo brasileiro, diversas obras são dedicadas à análise dos temas apontados por Rossellini. Cf. ABRAMO, Perseu. Padrões de manipulação na grande imprensa. São Paulo: Fundação Perseu Abramo, 2003, e ARBEX, José. Showrnalismo: a notícia como espetáculo. São Paulo: Casa Amarela, 2001.
} 
proximidade do cineasta em relação a eles, são os meios que analisa em detalhe. A televisão constitui "o mais potente e sugestivo dos meios de comunicação", porque dispõe "de uma audiência muito maior". Deveria ser, em decorrência disso, o meio "mais adequado para promover uma educação integral", ou seja, citando Gramsci, "uma nova Weltanschauung ${ }^{31}$ proletária", ou "um novo conceito de vida para o povo". Rossellini observa que, de acordo com Gramsci, seria preciso chegar "à criação de uma nova cultura integral, que tenha as características massivas da Reforma protestante e do Século das Luzes francês, as características do classicismo grego e do Renascimento italiano"; uma cultura que seja a síntese "de Maximilien Robespierre e Immanuel Kant", ou "da política e da filosofia em uma dialética intrínseca a um grupo social, nem francesa, nem alemã, mas européia e mundial" (ROSSELLINI, op. cit., p. 105).

Já o cinema, observa Rossellini, atravessava "grave crise", em parte devido à televisão, que "deitou raízes em nossa vida cotidiana". Assim, enquanto a "televisão estatal monopolista" - modelo vigente, à época, em países europeus como a Itália, a França e o Reino Unido transmitia programas a "espectadores já assegurados previamente", o cinema precisava conquistar, "filme por filme", os espectadores capazes de pagar os seus custos de produção. A televisão desfrutava assim um "privilégio incomparável".

O cinema busca então refúgio na repetição de fórmulas que já conheceram êxito comercial; explora as modas. $E$ por quanto tempo são válidas essas fórmulas? Sabemos por experiência que, tanto no cinema quanto em qualquer outro campo, a moda dura "o tempo de um suspiro".

\footnotetext{
${ }^{31}$ Literalmente, visão de mundo.
} 
O cinema se vê condenado assim ao suplício de Sísifo: é escravo de um sistema que o obriga a começar sempre do zero, a assumir uma ou outra vez o risco de supor adivinhar o que terá êxito, a buscar o que o público poderá gostar em momento oportuno, e tudo isso com margens de tempo incrivelmente breves (ROSSELLINI, op. cit., p. 108).

A avaliação não impede, contudo, que Rossellini acredite firmemente no papel educativo dos meios audiovisuais como difusores de conhecimento. O volume traz, entre seus anexos, um texto de 1963 em que o cineasta deixa claro seu apreço pela ideia de inserção do audiovisual na escola:

Os meios audiovisuais, com efeito, podem contribuir de forma eficaz para potencializar uma vasta obra de informação, de ilustração, de cultura entre os homens.

Cabe inventar fórmulas divertidas e atraentes para criar espetáculos que permitam ao público utilizar em proveito da cultura uma parte, ao menos, das muitas horas de tempo livre. Com isso, os homens seriam mais felizes e mais harmoniosa a convivência.

Eu me atreveria, ainda que mui timidamente, a formular uma sugestão aos artistas. Tolstoi dizia que em toda expressão artística é indispensável "um impulso emotivo". E como não sentir um impulso emotivo ao contemplar as conquistas levadas a cabo pelo homem durante os dois últimos séculos? Essa emoção irmana a arte com o destino do mundo em que vivemos. Pois uma profunda emoção nos invade ao pensar no homem, minúsculo e grande, enfrentando seus descobrimentos, as fronteiras e perspectivas que, com eles, tem conseguido abrir.

A escola deve servir de veículo para tal conhecimento, uma vez que sua tarefa é a de promover, por meio do acordo do homem com seu tempo, uma medida maior de humanidade e, em conseqüência, de civilização. $E$ com maior eficácia conseguirá esse objetivo se tiver em conta que sua atividade se inscreve hoje em um mundo que dispõe entre seus signos distintivos da imagem em movimento. 
Será assim possível um ensino mais fácil e agradável, que a amplitude de matérias a tratar ameaça tornar cada vez mais árduo e penoso.

Em 1900, Charles Pathé já havia anunciado: o cinema será o teatro, o jornal e a escola de amanhã.

Está demonstrado que o emprego inteligente dos meios audiovisuais, por si só ou em associação com outros sistemas de ensino, facilita a instrução e torna mais duradoura a recordação das coisas aprendidas (ROSSELLINI, op. cit., p. 145).

No que se refere à escola, Rossellini afirma que os meios audiovisuais "revelam uma singular eficácia didática", embora não se detenha nos aspectos que fariam deles instrumentos de tamanho valor. A "explosão educativa" deve necessariamente contar, segundo ele, com os meios audiovisuais como "aliados naturais e lógicos". Ele julga necessário, porém, fazer algumas observações a respeito de seu uso. Certas disciplinas, como Geografia e Ciências, "não podem ser ministradas em classes do tipo auditório, que habitualmente se proporcionam aos alunos, e sim naquelas de tipo visual". O material filmado, acredita o cineasta, poderia "nos facilitar mapas vivos" no ensino de Geografia.

Em Ciências, esse material teria o objetivo de "situar cada cientista em sua etapa correspondente, dentro da história do pensamento humano"; um "programa filmado" sobre Pasteur, por exemplo, "pode ser aproximado do significado da biologia, ao mostrá-la em momentos nos quais ataca o saber tradicional, o rompe para instaurar algo novo". Analogamente, em outras disciplinas nas quais prevalece o "conteúdo literário", a imagem "pode libertá-las de suas limitações abstratas, analíticas, dogmáticas". Por meio do ensino visual, a história "pode mover-se em seu terreno, e não ser volatizada em fatos e nomes", "abandonar o marco da história-batalha, para se constituir em seus dominantes sociais, econômicos e políticos", e 
"reconstruí-la não na vertente da fantasia, e sim na da ciência histórica, climas, costumes, ambientes, homens que tiveram relevo histórico e promoveram avanços sociais". Além disso, certos personagens, "reelaborados psicologicamente", podem dar origem, "por suas qualidades humanas", a módulos de ação. O mundo da arte, que corresponde para Rossellini à "geografia do espírito", precisa - a exemplo da Geografia - de cores e formas que "só as imagens podem proporcionar".

O material filmado pode igualmente "converter a escola-auditório em escola-laboratório, no que diz respeito às técnicas da indústria". A vida de uma indústria, em todas as suas articulações, só poderia revelar-se de maneira eficaz graças à imagem. 0 audiovisual a serviço do entendimento do mundo:

Não se trata de renunciar às virtudes pedagógicas da tradição escolástica, e sim de lhes conferir um estilo novo, que é o estilo de quem se coloca em condições de ver e, portanto, de compreender (ROSSELLINI, op. cit., p. 146).

Ver para compreender, graças à construção de um Éden do conhecimento - jardim de dados, ideias e associações, cultivado por todos e à disposição de todos. Rossellini era um crítico da "semicultura" alimentada pelos meios de comunicação de massa e, portanto, dos mecanismos utilizados pela publicidade para sustentá-la, mas forneceu nessas frases os termos-chave para a criação de um slogan poderoso, que qualquer profissional de propaganda e mercadologia aplaudiria, sobre a educação audiovisual.

Palavras de ordem à parte, suas reflexões apresentam referenciais para que se discutam, entre outros, os seguintes tópicos 
importantes à qualificação de professores para atuação na educação audiovisual:

a) embora considere que os meios de comunicação de massa gerem efeitos nocivos para a sociedade, exemplificados na disseminação do que chama de "semicultura", Rossellini não atribui a responsabilidade por esses efeitos aos meios, e sim aos grupos que os comandam (crítica de ordem, sobretudo, ideológica) e, por conseqüência, ao conteúdo produzido a partir de suas diretrizes. Ao tentar desconstruir os mecanismos de representação da sociedade por esses meios, utiliza linha de argumentação que coincide com a defesa da emergência, na sociedade midiática, dos estudos de crítica da mídia (no âmbito do jornalismo) e de educação para os meios (no âmbito da educomunicação);

b) a postura de acreditar que o problema social gerado pelos meios de comunicação de massa tem a ver com a gestão de seu conteúdo leva Rossellini a formular propostas para a programação do que seria uma TV educativa, no sentido pleno do termo. Assim, sua compreensão do potencial educacional das imagens em movimento e suas idéias sobre como transformá-las em obras (programas) configuram material de referência a todos os que estejam voltados para a realização educacional no espectro das emissoras públicas e privadas, e também no das produções independentes, alternativas e populares, inclusive aquelas realizadas, no âmbito da educação audiovisual, por crianças e jovens em escolas;

c) o "Éden do conhecimento" de Rossellini corresponde, tal como foi imaginado pelo cineasta na década de 1970, a um banco de imagens (programas) que descortinassem temas relevantes de diversas áreas do conhecimento. Hoje, esse banco equivaleria a uma imensa midiateca à disposição, sobretudo em escolas, de todos os 
interessados em percorrer seus múltiplos caminhos. Os avanços tecnológicos permitem, no entanto, que se vá além da referência material proposta por Rossellini como base de dados (a do videocassete) e se compreenda a sua proposta como precursora das possibilidades incomparavelmente mais amplas oferecidas pela internet e pelos meios digitais;

d) apesar da referência a um modelo de educação relacionado ao ensino técnico, a proposta de transformação da tradicional escolaauditório em escola-laboratório com base na conexão com a cultura audiovisual pressupõe, a partir mesmo dessa terminologia, o entendimento de que a educação audiovisual deve configurar-se, inovadora, em oposição aos princípios da educação bancária. 


\section{De paradigmas a inovações}

O neorrealismo italiano, de que Rossellini é protagonista, exerceu papel preponderante na constituição do cinema moderno. Os principais procedimentos de realização empregados pelos filmes que deflagraram o movimento e difundiram seus princípios no cenário internacional com o fim da II Guerra Mundial seriam gradativamente incorporados pelas mais diversas cinematografias, incluindo até mesmo a produção industrial norte-americana. Ainda mais significativo, no entanto, foi o fato de o neorrealismo propor-se a trabalhar sobre a realidade sociopolítica vivida pela Itália no pós-guerra ${ }^{32}$ e, com isso, atribuir a filmes relevância política até então insuspeita, ao menos no domínio da produção que circulava em salas comerciais. Não por acaso, como foi apontado no Capítulo 1, as ideias e ações do movimento estão nas raízes dos "cinemas novos", movimentos cinematográficos que eclodiram simultaneamente em diversos países, na virada dos anos 1950 para os anos 1960 e ao longo de toda essa década, como a Nouvelle Vague francesa e o Cinema Novo brasileiro ${ }^{33}$.

A emergência de um cinema de caráter autoral comprometido com a expressão do ponto de vista de seus realizadores sobre 0 mundo contribuiu para que o cinema adquirisse novo status, comparável, no campo das artes, ao da literatura. De fato, muitos dos cineastas que se organizaram nesses movimentos - em sua maioria,

\footnotetext{
32 Os primeiros filmes neorrealistas foram realizados ainda durante a II Guerra; Roma, cidade aberta, o primeiro a representar o movimento no exterior e a se tornar um ícone dele, começou a ser rodado quando tropas alemãs ainda se encontravam em solo italiano.

${ }^{33}$ Sobre o estabelecimento das tradições neorrealistas, cf. FABRIS, Mariarosaria. $O$ neo-realismo cinematográfico italiano, São Paulo: Edusp: Fapesp, 1996.
} 
jovens egressos de escolas de cinema e cursos universitários, e não mais autodidatas formados na própria atividade cinematográfica julgavam exercer papel semelhante ao dos escritores, intelectualizado e reflexivo. Não se consideravam, como Almeida gostaria de saber, representantes de atividade "mercantil", e sim artística (ainda que continuassem a depender dos mecanismos de mercado para ter seus filmes produzidos, distribuídos e exibidos, e chegarem assim ao público). As coordenadas do cinema narrativo clássico pareciam insuficientes para a busca desses objetivos; certa ambiguidade de sentido nasceu de procedimentos narrativos que promoveram avanços em relação ao modelo industrial dominante.

Em paralelo a esses fenômenos, o mesmo período histórico encontrou já solidificados em diversos países as cinematecas, os cineclubes e os cursos de cinema. Dessa forma, disseminou-se política de preservação, difusão e formação que favoreceu a cultura cinematográfica $^{34}$. Cabe ressaltar também que equipamentos cinematográficos mais leves e acessíveis do que os até então disponíveis abriram novas possibilidades de realização e difusão, tanto no âmbito profissional como no amador. Natural, portanto, que fossem estabelecidos nesse período marcos fundamentais para as relações entre o audiovisual e a educação. De um lado, cristalizou-se a ideia de que o cinema tem contribuição relevante a prestar à escola e à formação de crianças e jovens. De outro, a crescente popularização da TV criou novos hábitos de fruição de imagens e sons, fenômeno que, por ocupar em especial a agenda de crianças, passou a demandar atenção de pesquisadores do campo educacional, ainda que o preconceito social em relação a esse meio tenha contribuído para retardar a formulação de políticas.

${ }^{34}$ Cf. CORREA JR., 2010. 


\subsection{Cinema e educação: uma abordagem paradigmática}

No contexto acima condensado, a Organização das Nações Unidas para a Educação, a Ciência e a Cultura (Unesco) encomendou a produção de estudo para estabelecer diretrizes sobre a educação cinematográfica, sob a coordenação do holandês Jan Marie Lambert Peters. Publicado nos EUA e na Europa em 1961, o documento apresenta conceitos-chave não só para as conexões entre o audiovisual e a educação de crianças e jovens, mas também para o desenvolvimento, décadas mais tarde, de campo mais abrangente, o da educação para os meios, e que viria a englobar, além do cinema e da televisão, outras formas de comunicação, como o rádio e a imprensa.

O estudo pioneiro da Unesco, grande paradigma das atividades escolares que recorrem ao audiovisual, organiza-se em duas partes e oito capítulos.

A primeira delas, dedicada ao mapeamento dos "conteúdos da educação cinematográfica", divide-se em quatro capítulos: (I) objetivo e escopo da educação cinematográfica, com uma de suas subdivisões argumentando que "a tela nos torna cidadãos do mundo"; (II) compreensão da linguagem cinematográfica, requisito a ser trabalhado em torno da ideia de que ver (um filme) pode ser tão difícil quanto ler (um texto); (III) apreciação do cinema como forma de arte; e (IV) assimilação crítica do conteúdo cinematográfico, que conduziria à "liberdade das ilusões" e à "libertação".

Tais princípios devem ser invocados até hoje como argumentos em defesa da educação audiovisual. A ideia de "cidadania global", por exemplo, referenda o que Almeida apontava 30 anos antes, ao elogiar o cinema, em registro que talvez pareça ingênuo, por desempenhar 
papel até então exclusivo dos meios de transporte - "levar o homem aonde se encontra a imagem real". Na sociedade contemporânea, a familiaridade com as telas da mídia fez com que se perdesse um bocado da noção de que entrar em contato com experiências distantes das nossas, em termos geográficos e socioculturais, representou avanço extraordinário para os cidadãos da primeira metade do século $X X$.

Essa familiaridade é a responsável por tornar as novas gerações - desde cedo habituadas a encontrar cotidianamente "o mundo" no telejornalismo, para sublinhar o gênero de produto audiovisual a que se atribui a missão de levar ao espectador um resumo do que ocorreu de mais importante na cidade, no país e no planeta durante um ciclo de 24 horas - a talvez perder de vista o fato de que essas experiências são indiretas, operadas a partir de recortes, e mediadas por agentes, os gatekeepers, guardiões dos portões simbólicos dos meios de comunicação de massa, pelos quais certas informações passam, avaliadas pelos critérios de noticiabilidade dominantes naquele veículo, e muitas outras, não.

Cabe à educação audiovisual expor os mecanismos segundo os quais esse suposto passaporte para a cidadania global, via consumo do audiovisual, está sujeito a limitações e deformações. Daí a necessidade estratégica, na agenda cidadã da Educação Básica, de aprender a ver assim como aprendemos a ler. A produção audiovisual massificada que circula pelas diversas telas convida, com frequência, a experiências de caráter passivo; o acúmulo dessas experiências, sozinho, não garante a formação de perspectiva crítica. É preciso trabalhá-la, e a escola surge como um dos espaços preferenciais para isso, se o objetivo a atingir for o de tirar o véu que cobre as "ilusões" e promover a "libertação". 
A segunda parte do estudo trata de "possibilidades práticas" para a educação cinematográfica, e também está dividida em quatro capítulos: (V) métodos e técnicas de educação cinematográfica; (VI) educação cinematográfica em sintonia com o desenvolvimento etário e mental; (VII) educação cinematográfica na escola; (VIII) o treinamento do professor de cinema.

Delineia-se, no estudo, sólida estratégia de argumentação em defesa do cinema como instância formativa - e não se deve minimizar o valor simbólico de ter sido deliberada em âmbito transnacional, por escritório da Organização das Nações Unidas (ONU), instituição encarregada, mais no terreno simbólico do que no da geopolítica propriamente dita, pelo estabelecimento de preceitos e normas a serem seguidos por todos os seus integrantes. Pois o que agora se defendia não mais era um "bom" cinema em oposição a seu suposto correspondente, malvado e corruptor, como sustentava a disposição maniqueísta adotada pelos que viam, na educação cinematográfica, apenas a missão de definir o repertório adequado para consumo de mentes ingênuas - e, se constatada a ausência de tal repertório, também o papel de produzir material apropriado ao processo de controle de usos e costumes (e - por que não - ideias).

Diferentemente do que pregava a reação conservadora tratada no Capítulo 1, a visão da Unesco, tal como articulada no estudo de 1961, celebrava o cinema como experiência social (de fruição coletiva, reflexiva, de alteridade), associada à modernidade e cultivada sobretudo em salas de cinema, mas também na televisão, graças à exibição de filmes, tenham sido eles realizados originalmente para o cinema ou exclusivamente para a TV; e valorizava, como conteúdo a ser trabalhado na Educação Básica, o conhecimento do processo de criação de sentido operado pela sua linguagem, em sociedade na qual a 
presença do audiovisual tornava-se cada vez mais acentuada, devido à expansão da cultura cinematográfica e à popularização da TV.

Esses argumentos foram incorporados por diversas propostas de educação cinematográfica para crianças e jovens, dentro e fora da escola, e constituem, em conjunto com as ações ali sugeridas, a base de programas implantados e ainda hoje desenvolvidos em diversos países. O estudo da Unesco prega a necessidade de formação específica para o educador cinematográfico, mas revela contradições e lacunas que obrigam a atualização de seus princípios no âmbito da educação audiovisual hoje.

Em primeiro lugar, o entendimento nele presente de obra a ser contemplada por essa proposta de educação é o do longa-metragem de ficção, com pequenas menções ao formato de curta-metragem e ao modelo documental. Entre os 66 títulos relacionados em um de seus apêndices, dedicado a uma filmografia básica de educação cinematográfica para crianças e jovens, 55 são longas de ficção e apenas 11 são curtas (de animação e documentários).

Nada contra, evidentemente, à presença na lista de obras referenciais para a história do cinema como $O$ encouraçado Potemkin (Bronenosets Potyomkin, 1925), A nós a liberdade (À nous la liberté, 1931), Tempos modernos (Modern times, 1936), Ladrões de bicicleta (Ladri di biciclette, 1948), O terceiro homem (The third man, 1949) e Morangos silvestres (Smultronstället, 1957), e de longas enraizados na cultura popular norte-americana (e muito conhecidos em diversos países por conta da hegemonia da indústria cinematográfica dos EUA), como Matar ou morrer (High noon, 1952) e Juventude transviada (Rebel without a cause, 1955) ${ }^{35}$. Não se concebe hoje, no entanto, que

\footnotetext{
${ }^{35}$ A lista da Unesco aponta para cânones, mas faz omissão ilustrativa do mecanismo de retroalimentação de relações como essa: a de Cidadão Kane (Citizen Kane, 1941),
} 
um projeto de educação audiovisual despreze o imenso repertório de curtas-metragens à disposição em diversas mídias, muito menos a importância, crucial no âmbito escolar, de discutir os conceitos que orientam a realização e a apreciação de documentários, sobretudo diante do aspecto híbrido assumido por parcela significativa da produção contemporânea, que recorre amplamente a procedimentos característicos da ficção ${ }^{36}$.

Além disso, a adoção desse referencial cinematográfico acabava por excluir as obras audiovisuais exibidas pela TV que não correspondessem ao formato do filme para cinema ou do telefilme. Embora o estudo não use os termos que seguem, ele sugere, por omissão, considerar a existência de uma "boa" TV (aquela cuja programação viria de mídia "superior", o cinema) em contraste, se não com uma "má" TV (juízo de caráter preconceituoso que não parece caber em proposta progressista), então com uma TV de segunda linha, indigna da mesma atenção dirigida ao cinema. Já no início da década de 1950, tratava-se de postura equivocada, que desprezava o caráter inventivo de boa parte da programação pioneira da TV e o intercâmbio que se registrava entre profissionais de cinema e televisão ${ }^{37}$.

\footnotetext{
de Orson Welles (1915-1985), que à época ainda "não existia" como clássico porque a primeira enquete internacional que o traria em primeiro lugar no ranking de filmes mais importantes da história seria divulgada apenas em 1961 pelo British Film Institute (BFI). Realizada a cada 10 anos desde então pelo BFI, a enquete continuou em todas as ocasiões a trazer Kane em primeiro lugar; assim, ele tornou-se, independentemente de sua qualidade notável, menção quase obrigatória em listas de filmes mais importantes da história.

${ }^{36}$ Observatório privilegiado desse fenômeno é realizado anualmente em São Paulo e Rio de Janeiro, infelizmente ainda sem conexão significativa com os universos da Educação Básica e da formação de professores: o É Tudo Verdade - Festival Internacional de Documentários, criado em 1996 pelo crítico Amir Labaki. Desde 2000, o evento promove paralelamente a Conferência Internacional do Documentário. 37 Cf., a respeito da originalidade dramatúrgica e narrativa do seriado Além da imaginação (The twilight zone, 1959-1964), criado por Rod Serling (1924-1975), CAPUZZO, Heitor. O cinema além da imaginação, Vitória: Fundação Ceciliano Abel de Almeida, 1990.
} 
Outro aspecto excludente no estudo da Unesco é o de não se ocupar, propositalmente, com o uso do cinema como instrumento pedagógico, ou seja, como ferramenta paradidática. Decorreria daí, segundo o documento, a escolha do termo film-teaching, e não teaching film ${ }^{38}$. Seu recorte desprezava, portanto, o uso de filmes no contexto de disciplinas clássicas da Educação Básica, como Língua, Ciências, Matemática e História. Ao fazê-lo, negligenciava também aquela que se tornaria a mais ampla porta de entrada para o audiovisual na escola e, o que talvez seja ainda pior, desconsiderava a necessidade de formação do educador para o uso paradidático de obras audiovisuais.

Esse raciocínio trabalhava com o pressuposto de que a exibição escolar de obras audiovisuais voltada para outros fins que não a própria história e linguagem do meio pudesse prescindir de conhecimentos sobre... a história e a linguagem do meio. Como se "ilustrar" (termo usado pelo documento da Unesco) com um filme uma aula de História, por exemplo, correspondesse a atividade "neutra", que não envolvesse competências diretamente relacionadas a conhecimentos específicos no campo do audiovisual. Exibir um filme sem recorrer a esses conhecimentos para contextualizá-lo e explorá-lo devidamente, em suas múltiplas possibilidades de geração de sentido, equivaleria a soltar uma classe de alunos em um museu, por cerca de duas horas, sem qualquer espécie de mediação. Fruição, de alguma

\footnotetext{
${ }^{38} \mathrm{O}$ termo film-teaching traduziria com maior acuidade, na concepção da Unesco, a ideia de educação cinematográfica (termo que usamos aqui a partir da tradução do estudo em espanhol, La Educación Cinematográfica, e também a partir de indicação do próprio estudo de que, em francês, a expressão correspondente a esse campo seria éducation cinématographique). De acordo com o estudo, a expressão teaching film estaria associada, em inglês, ao uso do cinema como instrumento pedagógico, tema de que não pretendeu tratar.
} 
forma, haverá; mas, em contextos educacionais, talvez seja legítimo esperar mais.

É preciso lembrar que, à época de publicação do estudo da Unesco, o uso do audiovisual como ferramenta paradidática não era ainda tão explorado quanto hoje, em virtude de limitações tecnológicas; na pior das hipóteses, a escola precisava de projetor, filme disponível na bitola correspondente e alguém que soubesse operar o equipamento para materializar a "ilustração" em sala de aula ou auditório - ainda que houvesse também a possibilidade de assistir ao(s) filme(s) em questão em outros espaços, como salas comerciais, cineclubes e cinematecas. Esse dado de caráter restritivo, entretanto, não é apontado como justificativa; conceitualmente, o estudo considerava que o cinema como instrumento pedagógico passava ao largo da "educação cinematográfica" propriamente dita.

Não parece surpreendente, por extensão, que o conteúdo voltado para "o treinamento do professor de cinema" corresponda a apenas cinco páginas do estudo (em um total de 120). Curiosamente, o capítulo tem início com uma consideração que exigiria, em tese, postura distinta:

$\mathrm{Na}$ opinião do escritor inglês Stanley Reed ${ }^{39}$, o mais sério obstáculo no caminho para introduzir a educação cinematográfica na escola é o fato de que "muitos professores [...] têm uma compreensão indevida do cinema. De fato, as crianças de hoje provavelmente entendem melhor essa mídia do que muitos de seus professores. As mentes dos que foram escolarizados com as artes mais antigas e cresceram na tradição acadêmica não olham com frescor para o cinema $e$ enquanto pessoas educadas, falando em termos genéricos, podem ter maior discernimento em seu juízo

\footnotetext{
${ }^{39}$ Identificado como autor de Film teaching in England; a obra não está na relação de livros indicados pelo estudo em um de seus apêndices.
} 
sobre o conteúdo de um filme, mas elas são com frequência inferiores àqueles que têm menos educação e que abordam o cinema sem nenhuma inibição cultural" (PETERS, p. 101, tradução nossa).

Pois, se têm "compreensão indevida", como prepará-los para desenvolver compreensão mais apropriada? 0 estudo aponta sumariamente os tópicos de um programa de treinamento em "pedagogia cinematográfica", divididos em quatro grupos.

No primeiro, voltado para apresentar o "background do lazer e da comunicação visual", são relacionados:

1. O significado sociocultural do fenômeno do cinema e da televisão.

2. O lugar do cinema e da televisão na vida de crianças e jovens.

3. Os efeitos do contato com o cinema e a televisão na percepção, no pensamento e no comportamento de crianças e jovens.

No segundo bloco de tópicos, aparecem os "princípios nos quais a educação cinematográfica deveria ser baseada":

1. O conceito de educação cinematográfica.

2. A educação cinematográfica como parte da educação geral.

3. Resultados esperados da educação cinematográfica.

O terceiro bloco trata do conhecimento da "matéria-prima" a ser ensinada:

1. Elementos e estrutura da linguagem cinematográfica.

2. Princípios da estética cinematográfica.

3. Elementos de conteúdo cinematográfico e sua avaliação crítica.

4. Psicologia da experiência cinematográfica. 
No quarto bloco, são relacionados os tópicos sobre "conhecimento dos métodos e das possibilidades práticas da educação cinematográfica":

1. Instrução, discussão, estudo do cinema, atividades em oficinas.

2. Realização cinematográfica: roteiro, direção, operação de câmera, montagem, projeção.

3. A educação cinematográfica em sintonia com o desenvolvimento etário e mental dos estudantes.

4. Inserindo a educação cinematográfica no currículo escolar; educação cinematográfica como atividade extracurricular.

Feita a apresentação dos tópicos, encerra-se a preocupação do estudo da Unesco com a formação de professores capazes de implantar na escola a educação cinematográfica segundo os parâmetros libertadores ali propostos. A lacuna pode ser entendida - é o que fazemos neste trabalho - como um convite à reflexão sobre quais seriam os parâmetros materiais dessa formação.

\subsection{Televisão, vídeo e educação: uma abordagem inovadora}

Em duas obras que se complementam, Televisão e educação e Vídeo e educação (publicadas na Espanha, respectivamente, em 1994 e $\left.1995^{40}\right)$, o espanhol Joan Ferrés trouxe inestimável contribuição às reflexões sobre a presença do audiovisual na escola. Os conceitos que apresenta e as práticas que propõe constituem ainda hoje referencial teórico indispensável à formulação de políticas de

\footnotetext{
${ }^{40}$ A primeira edição de Vídeo e educação foi publicada originalmente na Espanha em 1988 e depois revista pelo autor, com diversos acréscimos e atualizações, para uma nova edição por outra editora, que consideramos neste trabalho, em sua edição brasileira.
} 
formação para a educação audiovisual. Ferrés aborda, assim como o estudo da Unesco, a necessidade de qualificação de educadores para desenvolvimento de atividades nessa área, mas, como se verá adiante, também não chega a planejar como se daria, em termos concretos, essa formação.

A importância de Ferrés para o campo de estudos sobre audiovisual e educação está diretamente relacionada à sua defesa de que a televisão e o vídeo devem estar presentes na Educação Básica. Para Ferrés, uma escola que não ensina como assistir à televisão é uma escola que, simplesmente, não educa. Seu raciocínio é o de que crianças e jovens lidarão com a presença da TV no cotidiano durante toda a vida:

A televisão representa para os cidadãos das sociedades modernas aquilo que o totem representava para as tribos primitivas: objeto de veneração e reverência, símbolo de identificação individual e coletiva... Como totem, a televisão concentra as expectativas e temores das tribos modernas. A ela sacrificam seu tempo. Ela dá sentido (?) à realidade. Decide o que é e o que não é importante. E produz o prazer de saber-se e sentir-se integrado dentro de uma coletividade. Para muitas pessoas a televisão é um compêndio de todas as suas esperanças: é aquilo que de mais importante ocorre em sua vida ao longo do dia (FERRÉS, 1996, p. 7).

Ferrés recorre ao aforismo célebre do canadense Marshall McLuhan (1911-1980), "o meio é a massagem - o meio é a mensagem", para sublinhar, em sua tomada de posição pelo estudo da TV na escola, a ideia de que as sociedades contemporâneas teriam sido (e continuariam a sê-lo) modeladas mais pelos tipos de meios usados por seus cidadãos para se comunicarem do que propriamente pelos 
conteúdos transmitidos por esses meios ${ }^{41}$. Mas, diferentemente do que se poderia imaginar com base no entendimento acima condensado, o autor espanhol não cerra fileiras nas trincheiras dos "integrados" (à indústria cultural, à sociedade tutelada simbolicamente pelos meios de comunicação de massa) na batalha contra os "apocalípticos" (que rechaçam integralmente a indústria cultural e a tutela social pelos meios de comunicação de massa), usando terminologia cunhada pelo italiano Umberto $\mathrm{Eco}^{42}$.

Em relação à TV, Ferrés considera que a postura "apocalíptica" é representada por abordagens que a consideram responsável pela homogeneização e degradação culturais, gerando alienação e provocando, direta ou indiretamente, alguns dos principais males sociais de nosso tempo. Já as posturas "integradas", segundo o autor, veem nela oportunidades para a democratização do conhecimento e da cultura, a ampliação dos sentidos e a potencialização da aprendizagem, celebrando a cultura da opulência e da diversidade. Entre uma e outra, Ferrés prefere "a aceitação crítica" e "o equilíbrio entre o otimismo ingênuo e o catastrofismo estéril", de modo a assumir "a ambivalência do meio", com suas possibilidades e limitações, e as suas "contradições internas". "A compreensão do meio deve ser realizada a partir da sua complexidade e não partindo da simplificação ou do maniqueísmo", afirma (FERRÉS, op. cit, p. 12).

A maneira mais adequada para dar conta dessa tarefa na escola, de acordo com Ferrés, seria a combinação de duas dimensões:

\footnotetext{
${ }^{41}$ Cf. MCLUHAN, 1969.

${ }^{42}$ Cf. ECO, 1993. Para abordagem "apocalíptica" da TV em chave sociopolítica, cf. POPPER e CONDRY, 1995, e BOURDIEU, 1997.
} 
Uma adequada integração da televisão à sala de aula pressupõe considerar duas dimensões da formação: educar na televisão e educar com a televisão.

Educar na televisão significa transformar o meio em matéria ou objeto de estudo, educar na linguagem audiovisual, ensinar os mecanismos técnicos e econômicos de funcionamento do meio, oferecer orientação e recursos para a análise crítica dos programas... Concluindo: realizar uma abordagem do meio partindo de todas as perspectivas: técnica, expressiva, ideológica, social, econômica, ética, cultural... Educar na televisão.

Mas também educar com a televisão. Incorporá-la à sala de aula, em todas as áreas e níveis do ensino, não para aumentar ainda mais o seu consumo, mas para otimizar o processo de ensino-aprendizagem.

$\mathrm{Na}$ realidade essas duas dimensões formativas complementam-se mutuamente. Quanto mais se educar com o meio, mais se educará no meio. Mas não basta atender a dimensão de educar com. É indispensável que na escola seja reservado um espaço e um tempo para a outra dimensão, porque há aspectos da televisão que devem ser atendidos de forma específica. Os alunos não podem ignorar os mecanismos internos e externos de funcionamento do meio de comunicação ao qual eles dedicam a maior parte do tempo (FERRÉS, op. cit., p. 92-93).

Coerente com a proposta acima descrita, Televisão e educação organiza-se em três partes. Na primeira, Ferrés apresenta as "chaves para compreender o meio", transitando por abordagens de natureza psicológica e sociológica. É analisada a televisão como "extensão da pessoa", "agente de consumo", "gratificação sensorial, mental e psíquica", "vitória do mito da objetividade", "meio de socialização" e "comunicação inadvertida".

Na segunda parte, que relaciona "chaves para educar no meio", são contemplados conteúdos referenciais à definição de critérios para o desenvolvimento de ações, com ênfase nos cuidados para lidar com a "teledependência" (a televisão analisada como "ladra" do tempo livre 
de crianças e jovens, Ihes reduzindo na agenda o espaço para outras atividades) e os "conteúdos violentos". Ferrés apresenta aqui uma de suas principais contribuições à reflexão sobre o audiovisual na escola: a proposta de um "método compreensivo" para trabalhar com a televisão (e plenamente adequada para trabalhar também com o cinema e com outras mídias). Trata-se de um ato de redução intelectual, para o autor, o hábito do professor - enraizado no ensino brasileiro, parece razoável afirmar, e por consequência lamentar - de abrir uma bateria de discussões sobre uma obra com perguntas como "O que o autor queria dizer?" ou "Qual é a mensagem do programa?".

Ao fazê-lo, o professor privilegia as dimensões de caráter lógico, racional e reflexivo, esquecendo que a comunicação audiovisual mobiliza, em primeiro lugar, as dimensões sensitiva e emocional. $\mathrm{Na}$ mediação que Ferrés considera mais adequada, o ponto de chegada, e não de partida, deveria ser o racional e o reflexivo. Assim, estariam invertidos os polos, mas com resultado equivalente: enquanto a experiência da televisão tem aspectos negativos associados ao fato de deixar costumeiramente a reflexão de lado, a sua incorporação pela escola, de acordo com esses parâmetros de exploração conteudística, estaria desequilibrada por deixar a emoção fora do processo de apreciação.

Uma abordagem crítica da televisão deveria ser feita sempre a partir da interação. A experiência televisiva é o resultado do encontro de um espectador - com a sua ideologia, a sua sensibilidade, os seus sentimentos, as suas emoções e valores - e um emissor - com a sua ideologia, os seus interesses explícitos e implícitos, os seus valores e o seu sentido da estética. E tanto o espectador como o emissor estão condicionados por um contexto social e cultural. Não se deveria prescindir de nenhuma dessas dimensões. 
Qualquer programa provoca no receptor reações de todo tipo: emotivas, ideológicas, éticas, estéticas... Se o espectador sente medo, é de algo ou de alguém. Se sente raiva ou agressividade, é contra alguém. Se sente compaixão, é por alguém. Todos esses sentimentos são o resultado de um encontro, de uma interação entre duas realidades, o espectador e o discurso. E tais sentimentos revelam uma forma de entender o meio e uma forma de entender a realidade (FERRÉS, op. cit., p. $81)$.

Em termos materiais, a obra em exibição, em qualquer tela, é rigorosamente a mesma para todos os espectadores (com as mesmas imagens, os mesmos sons e a mesma duração), mas gera experiência que não é idêntica, jamais, para duas pessoas. Cabe à educação audiovisual lidar com esse aspecto fascinante da fruição audiovisual: embora se concretize muitas vezes de acordo com circunstâncias de apreciação coletiva, ela termina por adquirir significado tão individual quanto a experiência de fruição literária, tamanhos os condicionantes de ordem pessoal que interferem no sentido que atribuímos ao que vemos.

Por fim, a terceira parte, de caráter instrumental, traz detalhadas propostas metodológicas para a análise de programas, em espectro -hoje limitado diante da variedade da programação - que cobre publicidade, séries e telefilmes de ficção, e noticiários ${ }^{43}$.

E a formação específica do educador para aplicar esses conceitos, tendo em vista que o próprio Ferrés aponta, ao longo da obra, deficiências relacionadas ao despreparo de professores da Educação Básica para lidar com a televisão e os equívocos decorrentes dessa falta de qualificação? O autor tem algo a dizer a respeito do tema apenas em sua outra obra referencial, Vídeo e educação. E o

\footnotetext{
${ }^{43}$ Sobre a atual multiplicidade de programas da TV brasileira, cf. ARONCHI DE SOUZA, José Carlos, Gêneros e formatos na televisão brasileira, São Paulo: Summus, 2004.
} 
faz, brevemente, em somente dois trechos: no terceiro tópico - "Uma adequada utilização didática do vídeo exige dos professores uma formação específica" - do Capítulo 3, "Critérios para a utilização didática do vídeo", e no sétimo e derradeiro tópico - "Formação do professorado" - do último de seus 11 capítulos, "Projeto pedagógico para a integração do vídeo na escola".

Somadas, as considerações ocupam cerca de duas páginas (em um total de 156). A tecnologia do vídeo, segundo o autor, "tem chegado demasiado tarde na escola se nos detivermos nos contextos social e cultural", mas muito rápido "se pensarmos no que diz respeito à formação do professorado". Daí que as causas principais da nãointegração do audiovisual na escola seriam "a desmotivação e o despreparo por parte do professorado". Mas a linguagem audiovisual não seria, como pensam muitos, universal e imediatamente compreensível por todos que tenham sido expostos a ela desde a infância, dispensando assim cuidados específicos de formação? Essa "velha consideração" tornou-se, para Ferrés, "inaceitável".

Os pontos que seguem na argumentação do autor nos interessam, em especial. Em primeiro lugar, ele considera que não haverá professores formados para o emprego do vídeo e os demais meios audiovisuais "se não houver professores formados mediante o emprego do vídeo e dos demais meios audiovisuais" - ou seja, a formação para a educação audiovisual deve ser organizada e realizada de acordo com os princípios da própria educação audiovisual. As escolas de formação de professores teriam essa "nova exigência" para acrescentar a seus programas.

Ferrés admite, em seguida, que nem toda a capacitação necessária para utilizar corretamente o audiovisual pode ser adquirida nas escolas que formam professores. E, citando obra de Pierre Babin e 
Marie France Kouloumdjian ${ }^{44}$, observa que "o grande desengano do audiovisual [na escola] é que os professores não são audiovisuais", no sentido de sua formação não lhes ter preparado para se sentirem tão à vontade com os meios audiovisuais quanto com a caneta ou o giz. Dessa forma, haveria, além da necessidade de "preparação técnica, tecnológica, expressiva e didática", um "problema de sensibilidade" a exigir "uma adaptação a uma nova cultura, a uma nova maneira de pensar, de ser e de se comunicar". (FERRÉS, 1996b, p. 35-36)

A formação do professor seria, então, "o problema mais urgente" a enfrentar para se conseguir "uma integração plena e coerente do vídeo no ensino":

A partir do ponto de vista do audiovisual como matéria de estudo (pedagogia da imagem), a formação do professor envolve o conhecimento da linguagem audiovisual e dos mecanismos de funcionamento dos meios de comunicação de massa, além da capacidade didática de educar os alunos nesse âmbito.

Sob o enfoque do audiovisual como recurso para o ensino (pedagogia com a imagem), a formação do professor envolve conhecimentos em níveis técnico, expressivo e de aplicação didática para cada um dos meios. Somente alcançando a especificidade técnica e expressiva de cada meio poderão ser aproveitadas todas as potencialidades didáticas (FERRÉS, op. cit., p. 149).

Ferrés enxerga vantagens em cursos de formação realizados na própria escola. Pode-se adaptar o conteúdo à tecnologia e às demais condições estruturais com as quais os professores vão posteriormente trabalhar, e todo o corpo docente da instituição (ou toda a sua parcela que virá a trabalhar mais diretamente com o audiovisual) recebe a mesma formação, "com a possibilidade de que se estimulem e motivem

${ }^{44}$ Cf. BABIN e KOULOUMDJIAN, 1989. 
mutuamente e então trabalhem juntos". É "indispensável", segundo ele, o trabalho de pesquisa. Seminários de aplicação do audiovisual às diversas áreas do ensino "permitem pesquisar, experimentar e avaliar formulações mais criativas" no seu emprego didático (FERRÉS, op. cit., p. 149).

Assim como faz o estudo da Unesco, Ferrés menciona em Vídeo e educação apenas diretrizes muito genéricas para a formação de educadores em audiovisual. Sua abordagem, nesta obra, é ainda mais instrumental do que a de Televisão e educação, em que somente a terceira e última das partes tem foco metodológico. Dos 11 capítulos que compõem o livro, apenas o primeiro, "Educação audiovisual", obedece a natureza mais teórica do que prática, ao alinhavar conceitos sobre a presença dos meios audiovisuais na sociedade e a urgência de a escola incorporar sua linguagem. Em relação ao vídeo, a ênfase dessa incorporação deve residir nas formas de expressão por meio de imagens e sons, e não nos aparatos tecnológicos em torno delas, com o objetivo de promover uma "educação em estéreo", em contraposição à "educação em mono" (na qual prevalece o aspecto monofásico, ou de "mistura sobre uma faixa só, quando um dos aspectos do conhecimento ou da formação se ergue ditatorialmente sobre outro"), analogia com o próprio universo da linguagem audiovisual, que vai buscar novamente em Babin e Kouloumdjian:

É necessário introduzir aqui um conceito-chave na utilização didática do vídeo: a comunicação. Se a epistemologia da televisão começa e quase termina no plano do visceral, se mostra pessoas e situações diante das quais se relaciona de uma maneira quase estritamente emocional, uma educação em estéreo utilizará a comunicação, o diálogo e a confrontação para facilitar a passagem das emoções ao hemisfério da 
reflexão e da racionalidade. Do mono ao estéreo. Do homem fragmentado ao homem completo.

[...] $\mathrm{O}$ audiovisual de grupo nasce com vocação de servir a uma educação em estéreo. Assume o melhor dos meios de massa (uma forma específica de expressão que se conecta com a sensibilidade do homem de hoje) e da cultura do livro (o caráter personalizador, conseguido agora por intermédio da comunicação). E faz frente aos excessos de cada um deles.

Essa formulação pedagógica atinge o aluno em sua especificidade e em sua integridade, preenche, também, as possibilidades expressivas dos meios audiovisuais e facilita a unificação do ambiente cultural. Finalmente, assim concebido, o vídeo didático facilita a coerência entre a sensibilidade do aluno, a especificidade do meio e a evolução do sistema social.

A educação em estéreo transforma a escola não em um centro de ensino, mas de aprendizagem. Um centro preocupado não pela simples transmissão de conhecimentos, mas pelo enriquecimento em experiências de todo o tipo: conhecimentos, sensações, emoções, atitudes, intuições... É a oportunidade de o aluno elaborar um projeto próprio de personalidade por intermédio da integração de todas as suas faculdades físicas e psíquicas mediante a inter-relação constante com o grupo, com a aula, com a escola, com a sociedade em geral (FERRÉS, op. cit., p. 17-18).

Trata-se de utopia que demandaria, para sua concretização, profunda reforma dos sistemas educacionais, tais como se apresentam em países como a Espanha e o Brasil, e da própria escola como instituição que alimenta naturalmente, por sua própria estrutura hierárquica e por sua dinâmica de funcionamento, atitudes de caráter conservador e autoritário. A escola vislumbrada por esse exercício de imaginação utópica contribui, no entanto, para estabelecer parâmetros concretos e plenamente realizáveis com o objetivo de formular, na análise de Ferrés, um "marco pedagógico para o audiovisual" - o que se espera dele na Educação Básica, e como trabalhar para concretizar essas metas - no âmbito de uma escola "aberta" (que envolve uma 
pedagogia centrada na aprendizagem, ou aprender a aprender), em contraposição à escola tradicional, "fechada" (que privilegia visão de mundo preestabelecida, e pedagogia unidirecional e didática, baseada na transmissão de conteúdos verbais para memorização) (FERRÉS, op. cit., p. 28-29). 


\section{Novos cenários}

Qual o lugar do audiovisual na sociedade contemporânea? A resposta a essa pergunta exige mais tempo e implica mais incógnitas, hoje, do que ao ser formulada há cerca de três décadas. Naquele momento, mesmo os avanços tecnológicos já então registrados na produção e difusão de obras audiovisuais - à época, resumidas a filmes para cinema, a telefilmes, ficção seriada e demais programas convencionais de televisão, e a uma incipiente atividade, predominantemente de caráter experimental, em vídeo - possibilitavam especular a respeito de transformações profundas na economia do setor $^{45}$. Ainda não permitiam, contudo, que fosse vislumbrado o atual cenário, muito menos seus efeitos sobre os modos de produção, circulação e consumo de imagens e sons, com respectivos impactos na sua recepção e na percepção do espectador.

Compreender como se articula o espaço para o audiovisual hoje ou como se manifesta socialmente a cultura audiovisual - representa tarefa obrigatória para o entendimento de como pode, em consequência disso, ser promovida a educação audiovisual de crianças e jovens na escola. Acentuadas nos últimos 10 anos, as mudanças de caráter tecnológico, econômico e social interferem no aparato e na infra-estrutura à disposição das práticas, bem como em aspectos conceituais associados aos modos de expressão de crianças e jovens

\footnotetext{
45 Sintomático daquele estágio é o uso do termo "cinema eletrônico" para se referir às contribuições levadas até ele pelos computadores e pelo vídeo, como se nota nos documentários que acompanham a cópia em DVD do longa-metragem $O$ fundo do coração (One from the heart, 1982), de Coppola.
} 
por meio de imagens e sons. 0 diagnóstico desse quadro determina parâmetros fundamentais para a formação de professores para a educação audiovisual.

De amplitude global, o atual cenário no campo do audiovisual resulta de transformações recentes nas esferas de produção, de difusão e de armazenamento, além de uma nova configuração dos mercados pelos quais escoam as obras e dos meios alternativos pelos quais circulam também manifestações audiovisuais desvinculadas de preocupações mercadológicas, como se verá nos tópicos deste capítulo. O último desses tópicos aponta, no campo da educação brasileira, aspectos contemplados por reformas curriculares na Educação Básica - e, especialmente, novos parâmetros para o Ensino Médio - que favorecem a presença do audiovisual na escola. Ainda que em determinadas situações essa presença não seja explicitamente prevista, está contemplada por diretrizes que a encampam.

\section{$\underline{3.1 . ~ P r o d u c ̧ a ̃ o ~}$}

Os aparelhos e suportes de captação de imagens e sons foram, do final do século XIX até os anos 1950, de uso quase exclusivo da indústria cinematográfica, das emissoras de televisão e das produtoras de filmes publicitários, em virtude dos custos elevados para sua compra ou aluguel e manutenção, além da necessidade de pessoal especializado para operá-los. O desenvolvimento e a comercialização em ampla escala de câmeras cinematográficas nas bitolas $16 \mathrm{~mm}, 8$ $\mathrm{mm}$ e super-8, bem como de equipamentos portáteis para captação de som, notadamente a partir dos anos 1960, trouxeram não só contribuições à atividade profissional em cinema, televisão e publicidade; possibilitaram também a realização amadora, no domínio 
de instituições públicas e privadas $^{46}$ e no âmbito doméstico ${ }^{47}$, e permitiram que a produção de filmes fosse incorporada pela escola no âmbito da educação audiovisual, como se viu no Capítulo 2.

São representativas desse período, por exemplo, obras referenciais de ênfase técnica como Film in teaching, de Keith Kennedy, publicada na Inglaterra em 1972, e In focus: a guide to using films, de Linda Blackaby, Dan Georgakas e Barbara Margolis, publicada nos EUA em 1980. Com o objetivo de apresentar ao professor o universo de equipamentos e suportes à disposição de escolas para a realização de filmes, esses livros têm capítulos que se confundem com catálogos de lojas especializadas, ao relacionar, em caráter de apresentação didática, os aparelhos de realização então disponíveis para atividades educacionais.

Salto considerável na esfera da produção audiovisual foi dado, na década de 1980, com o barateamento e a consequente ampliação de oferta e consumo de equipamentos para a captação e reprodução de vídeo magnético. De forma muito mais numerosa e socialmente espraiada do que havia ocorrido com as câmeras super-8, até então a modalidade mais facilitadora de realização não profissional, as câmeras de vídeo e os gravadores de videocassete fizeram com que atividades até então amadoras adquirissem status profissional - desfrutado, por exemplo, pelos cinegrafistas que registram casamentos, formaturas, festas e convenções, entre outros eventos - e transformaram a rotina

${ }^{46}$ O longa-metragem Amador (Amator, 1979), de Krzysztof Kieslowski (1941-1996), faz uma extraordinária abordagem dessa situação por meio do dilema moral vivido por um operário que, graças à sua câmera super-8, a única da cidade, torna-se cinegrafista oficial da empresa estatal onde trabalha e adquire outra perspectiva social.

${ }^{47}$ Cf. BEAL, 1976. 
de famílias que usavam a gravação de momentos públicos e privados como substituto ou complemento do registro fotográfico.

Exemplo de incorporação pela escola desse novo estágio na história da produção audiovisual reside na obra do espanhol Joan Ferrés, já abordada no Capítulo 2, e em livros instrumentais como Teaching youth media: a critical guide to literacy, video production, and social change, de Steven Goodman, publicado nos EUA em 2003; Le caméscope au quotidien: fiches pratiques pour une pédagogie de la vidéo à l'école primaire, de Francis Commagnac e Bertrand Barilly, publicado na França em 2003; e ¿Es fácil hacer cine en la escuela con pocos recursos y muchos resultados?, de Alejandro Cobo, publicado na Argentina em 2008.

Nada disso se compara, no entanto, às possibilidades abertas pela chamada "revolução digital" para a captação e edição de imagens e sons. A partir dos anos 1990, câmeras digitais de operação simplificada e preços acessíveis às classes B e C substituíram os equipamentos de vídeo analógico; instalados em computadores, programas de operação também amistosa para o leigo passaram a possibilitar, no âmbito doméstico, a edição e o uso de efeitos. Hoje, os equipamentos digitais capazes de fazer a captação de imagem e som se multiplicaram: além das câmeras convencionais de vídeo, oferecidas pelo mercado em amplo espectro de preço e qualidade, há também câmeras fotográficas com dispositivo para registro de imagens em movimento, webcams e câmeras instaladas em aparelhos de telefonia celular - alguns dos quais saídos de fábrica com recursos simplificados de edição e de produção de efeitos, dispensando até mesmo que o material seja descarregado em computador.

No domínio conceitual, um dos principais aspectos dessa avalanche não mensurável de produção audiovisual está relacionado a 
certa dimensão narrativa, e foi abordado pelo francês Paul Virilio ao se referir, ainda no início dos anos 1980, à crise das "grandes narrativas" (aquelas que teriam por missão explicar as circunstâncias de experiências coletivas, como as sociais e históricas), muitos antes que a revolução digital e a cibercultura, por meio sobretudo dos blogs, provocasse uma explosão na circulação de micronarrativas cotidianas, matéria-prima privilegiada da produção caseira de imagens e sons:

Às grandes narrativas de causalidade teórica sucederam-se assim as pequenas narrativas de oportunidade prática e, finalmente, as micronarrativas de autonomia. A questão que se coloca, portanto, não é mais a da "crise de modernidade" como declínio progressivo dos ideais comuns, protofundação do sentido da História, em benefício de narrativas mais ou menos restritas ligadas ao desenvolvimento autônomo dos indivíduos, mas antes a questão da narrativa em si, ou seja, de um discurso ou modo de representação oficial, herdeiro da Renascença e até o momento ligado à capacidade universalmente reconhecida de dizer, descrever e inscrever o real. Desta forma, a crise da noção de "narrativa" se mostra como a outra face da crise da noção de "dimensão" como narrativa geometral, discurso de mensuração de um real visivelmente oferecido a todos.

A crise das grandes narrativas que deu lugar às micronarrativas revela-se finalmente como a crise da narrativa do "grande", bem como do "pequeno", advento de uma desinformação em que a desmesura e a incomensurabilidade estariam para a "pós-modernidade" assim como a resolução filosófica dos problemas e a resolução da imagem (pictorial, arquitetural...) estiveram para o nascimento das "luzes" (VIRILIO, 1993, p. 18).

Pontos a destacar no que diz respeito à educação audiovisual:

a) crianças e jovens, agora, têm familiaridade com os equipamentos necessários para a produção ou, na pior das hipóteses, estão habituadas a lidar com as tecnologias utilizadas para isso, 
reduzindo brutalmente os esforços imprescindíveis à apresentação desses equipamentos e ao seu uso;

b) os investimentos a serem feitos por redes de ensino e por escolas se tornaram reduzidos, quando não, em certas comunidades, até desnecessários, pois os próprios alunos dispõem de infraestrutura mínima para realizar exercícios básicos de captação e edição;

c) a predominância das "micronarrativas" na produção audiovisual de crianças e jovens pode respaldar os compromissos da escola com o fortalecimento das identidades individuais e coletivas.

\subsection{Difusão}

O tripé formado por produtores, distribuidores e exibidores cinematográficos controlou exclusivamente, nas primeiras três décadas do século XX, a difusão de obras audiovisuais. Para assistir a um filme, era preciso que uma distribuidora o programasse em uma sala de cinema localizada ao alcance geográfico do espectador - que, por sua vez, precisava também ter condições de pagar pelo ingresso ${ }^{48}$. A experiência cinematográfica era governada por esses agentes, em forma de negócio que ocupava espaço bem definido e restritivo em termos de consumo.

$\mathrm{Na}$ década de 1930, o circuito de exibição de obras cinematográficas começou a ser ampliado com a criação de cinematecas, clubes de cinema e salas especiais instaladas em embaixadas, consulados e instituições culturais. Em paralelo à exibição

\footnotetext{
${ }^{48} \mathrm{Na}$ virada do século XIX para o século XX, em que ocorre a estruturação de circuito exibidor exclusivo para a atividade cinematográfica, os espaços para projeção eram ainda mais variados e as condições, irregulares. Filmes eram exibidos em parques e feiras de diversões, casas noturnas, cafés, bares e teatros.
} 
de caráter comercial, passou a ser difundida também a exibição de caráter cultural, muitas vezes sem cobrança de ingresso. A programação desses espaços alternativos, no entanto, continuou a depender da disponibilidade de cópias. Quando elas não pertenciam ao acervo de cinematecas, representações diplomáticas e instituições culturais, era preciso recorrer às distribuidores que dispunham dos respectivos direitos de exibição.

A entrada em operação das emissoras de TV de sinal aberto, públicas e privadas, popularizou, a partir da década de 1950, uma nova janela, agora doméstica, para a exibição de filmes - sessões "gratuitas", como na difusão cinematográfica cultural ${ }^{49}$-, criando, entretanto, modos de consumo distintos daqueles oferecidos em salas de cinema ${ }^{50}$. Essa nova janela, por sua vez, ganhou também programação exclusiva, composta de telefilmes, ficção seriada, noticiários e programas diversos. A oferta audiovisual que circula por ela foi dramaticamente ampliada com a entrada em operação dos canais pagos de $\mathrm{TV}^{51}$, cujas operadoras se aproveitam de uma

\footnotetext{
${ }^{49}$ No Reino Unido, o Estado cobra imposto sobre aparelhos domésticos para obter os recursos que mantêm o sistema público de rádio e televisão; no modelo hegemônico internacional, que prevaleceu no Brasil, a publicidade veiculada durante a programação gera receitas para a emissora e o espectador, de forma indireta, paga por ela ao adquirir produtos cujos preços embutem o valor gasto na publicidade. ${ }^{50}$ Os modos de consumo específicos dessa nova tela envolvem fatores como a audiência em número reduzido (muitas vezes, a uma única pessoa) contraposta à experiência social das salas de cinema, os fatores concorrenciais de atenção (reduzidos ao máximo nas salas de cinema, mas de presença quase inevitável em residências) e as condições de iluminação e som impróprias para a imersão na narrativa. ${ }^{51}$ Nos EUA, onde o modelo mais rapidamente se desenvolveu, com a oferta de centenas de canais segmentados, a novidade se expandiu nos anos 1970; no Brasil, chegou ao telespectador apenas nos anos 1990, e inicialmente a valores que reduziram seu alcance às classes $A$ e B.
} 
modalidade específica, a do pay-per-view (pague para ver), para abrir uma subjanela dominada quase exclusivamente por obras cinematográficas (ali exibidas durante o intervalo entre seu lançamento nos cinemas e a chegada aos canais pagos de TV).

Os aparelhos de videocassete, no final da década de 1970, e os de DVD, no final dos anos 1990, ofereceram uma nova possibilidade de consumo doméstico e corporativo de obras audiovisuais, por meio da compra ou do aluguel de fitas e discos. Além de estabelecimentos comerciais voltados para esse fim, acervos - em geral, de acesso gratuito - passaram a ser montados por instituições públicas e privadas, em bibliotecas ou midiatecas. Até aquele momento, contudo, os agentes do negócio audiovisual ainda exerciam controle efetivo econômico e comportamental - sobre a circulação de mercadorias, que passou a ser afetado, de maneira ainda tímida na década de 1990, mas incisiva ao longo dos anos 2000, pela "revolução digital".

A ampliação do acesso à internet - não só por meio de computadores, mas também com o uso de telefones celulares, aparelhos de MP4 e tablets - criou novas janelas para a circulação do audiovisual produzido para cinema e TV, tanto em respeito à legislação de direitos autorais como à revelia dela, mas também gerou, o que configura novidade ainda mais impactante, intensa circulação de obras - sobretudo de curta-metragem - que não eram contempladas pela lógica comercial do cinema e da TV, ou nem mesmo eram realizadas antes que houvesse a possibilidade de difusão.

Essas duas ramificações da produção audiovisual da atualidade a convencional, movida pelas engrenagens econômicas do setor, e a alternativa, que se realiza independentemente dos parâmetros clássicos que regulam a atividade no âmbito capitalista e profissional, embora às vezes até possa flertar com eles - encontram outras janelas 
de exibição, ou então são apenas referenciadas, no universo das redes sociais estabelecidas na internet. Em ambos os casos, os modos de consumo passam por transformações ${ }^{52}$.

Nas redes sociais, os agrupamentos de espectadores organizamse de modo até então inédito, em comunidades virtuais extraordinário avanço em relação a antigas modalidades de agrupamento no universo do audiovisual, como os clubes de fãs e os grupos de estudos, com repercussões na economia do audiovisual, obrigando a escola a refletir sobre a apropriação desse fenômeno pela sociedade de consumo.

Se nos anos 80 a segmentação das bases consumidoras prenunciava-se como alternativa à homogeneização de gostos pelas indústrias culturais, hoje a chamada hipersegmentação consolida-se como um dos alvos centrais das práticas mercadológicas. A massificação da audiência continua sendo a bitola preferencial de redes de televisão aberta, emissoras de rádio AM e periódicos de grande circulação - mas os veículos de comunicação investem, simultaneamente, na fragmentação e no reagrupamento de consumidores por interesses afins. Os usuários formam comunidades autônomas, de tamanhos substantivos e capacidade de respostas imediatas aos estímulos de meios de promoção. Cabe aos aparatos de publicidade e marketing estudar suas aspirações para vinculá-las a mercadorias e serviços diversificados. Significa perceber tais grupos como moléculas que inscrevem necessidades, valores e distinções sociais na escolha de bens de consumo desmassificados. Bernard Arnault, proprietário das marcas de moda mais sofisticadas do mundo, interpreta a evolução de parâmetros: "As pessoas, hoje em dia, têm um certo desejo de reconhecimento. De pertencer a uma espécie de clube. A diferenciação nas sociedades

52 O cineasta norte-americano David Lynch, por exemplo, usa redes sociais como o Facebook e o Twitter para realizar e difundir sua obra atualmente em progresso, a série de entrevistas Interview project, hospedada na internet. 
que progridem será feita ainda mais pelo que se consome" (MORAES, 1998, p. 177).

Com as redes sociais e as comunidades virtuais, a cultura audiovisual torna-se elemento de auxílio à constituição de identidades, individuais e grupais. Diga-me os filmes de que gosta, os seriados que acompanha, o telejornal no qual acredita e seu integrante preferido no reality show do momento, e te direi quem és. Ou, se preferir, os filmes de que não gosta, os seriados que não acompanha, o telejornal no qual não acredita e o integrante que considera mais infeliz no reality show do momento.

As novas tecnologias da informação estão integrando o mundo em redes globais de instrumentalidade. A comunicação mediada por computadores gera uma gama enorme de comunidades virtuais. Mas a tendência social e política característica da década de 90 é a construção da ação social e das políticas em torno de identidades primárias - ou atribuídas, enraizadas na história e geografia, ou recém-construídas, em uma busca ansiosa por significado e espiritualidade. Os primeiros passos históricos das sociedades informacionais parecem caracterizá-las pela preeminência da identidade como seu princípio organizacional. Por identidade, entendo o processo pelo qual um ator social se reconhece e constrói significado principalmente com base em determinado atributo cultural ou conjunto de atributos, a ponto de excluir uma referência mais ampla a outras estruturas sociais. Afirmação de identidade não significa necessariamente incapacidade de relacionar-se com outras identidades (por exemplo, as mulheres ainda se relacionam com os homens), ou abarcar toda a sociedade sob essa identidade (por exemplo, o fundamentalismo religioso aspira converter todo mundo). Mas as relações sociais são definidas vis-à-vis as outras, com base nos atributos culturais que especificam a identidade (CASTELLS, 1996, p. 38). 
A organização social em comunidades não é exclusividade do momento histórico em que desponta a cibercultura, mas é potencializada por ela e, assim, adquire novos contornos. Estar ou não em redes - o que, para as novas gerações, integradas desde cedo ao ciberespaço, representa estar ou não n' $A$ Rede, estar disposto ou não a participar de trocas sociais no ambiente virtual - implica lidar com situações de inclusão e exclusão que reverberam com energia no ambiente escolar, entre outros.

Embora a forma de organização social em redes tenha existido em outros tempos e espaços, o novo paradigma da tecnologia da informação fornece a base material para sua expansão penetrante em toda a estrutura social. Além disso, eu afirmaria que essa lógica de redes gera uma determinação social em nível mais alto que a dos interesses sociais específicos expressos por meio das redes: o poder dos fluxos é mais importante que os fluxos do poder. A presença na rede ou a ausência dela e a dinâmica de cada rede em relação às outras são fontes cruciais de dominação e transformação de nossa sociedade: uma sociedade que, portanto, podemos apropriadamente chamar de sociedade em rede, caracterizada pela primazia da morfologia social sobre a ação social (CASTELLS, op. cit., p. 497).

Pontos a destacar no que diz respeito à educação audiovisual:

a) já não se faz indispensável, para a escola, recorrer aos mecanismos tradicionais de difusão para inserir o audiovisual em seu cotidiano, embora tais práticas devam ser contempladas para acentuar as distinções entre modos de consumo e padrões estéticos dominantes em cada uma das janelas de exibição ou, no jargão dos portais de internet, fontes de tráfego; 
b) a multiplicidade de janelas pelas quais circula hoje a produção audiovisual implica diversidade formal, social, econômica e política que deve ser contemplada para o devido entendimento de seu papel na sociedade;

c) a cibercultura e as redes sociais representam uma maneira potencialmente eficaz, na escola, de disseminar a cultura audiovisual, à margem dos mecanismos tradicionais de exibição ou em paralelo a eles.

\subsection{Armazenamento}

Até o início dos anos 1980, os projetos de educação audiovisual eram limitados, para a exibição de obras, aos acervos em película de cinematecas e filmotecas. A popularização do videocassete acrescentou ao cenário novos acervos - disponíveis em videolocadoras, videotecas e coleções particulares - cujas obras tinham exibição facilitada por tecnologia amistosa e de amplo acesso. Na década de 1990, o DVD deu início ao processo de substituição do videocassete, mantendo, em relação à localização de acervos, a mesma configuração do suporte anterior. A indústria do entretenimento aposta que o BluRay substituirá nos próximos anos o DVD, sem prejuízo, novamente, da configuração de acervos.

Em paralelo ao armazenamento de obras em cinematecas, filmotecas, videolocadoras, mediatecas e coleções particulares, os anos 2000 consolidaram, fruto da "revolução digital", acervos audiovisuais on line. Alguns deles podem ser acessados gratuitamente; outros exigem o pagamento de assinaturas ou de pay-per-view. Por meio de streaming, não é necessário baixar os arquivos; um player - programa de exibição multimídia em computadores - os executa no momento da conexão. 
O cenário parece confirmar a hipótese, desenvolvida nos anos 1990, de que a cibercultura trabalharia no futuro - que, tudo indica, já nos alcançou - a informação personalizada. Locadoras de filmes e sítios da internet que oferecem indicações de títulos processam dados sobre preferências (e também contrapreferências) de clientes ou interessados para lhes sugerir por onde prosseguir em sua aquisição de repertório, assim como programas instalados em aparelhos de MP3 fazem o mesmo a partir de coordenadas oferecidas pelo usuário, criando sessões personalizadas de canções, e sítios de livrarias na internet recomendam obras e autores com base em experiências anteriores que, segundo o leitor, foram gratificantes.

Na era da pós-informação, o público que se tem é, com freqüência, composto de uma única pessoa. Tudo é feito por encomenda, e a informação é extremamente personalizada. Uma teoria amplamente difundida afirma que a individualização é a extrapolação do narrowcasting - parte-se de um grupo grande para um grupo pequeno; depois, para um grupo menor ainda; por fim, chega-se ao indivíduo. Quando você tiver meu endereço, meu estado civil, minha idade, minha renda, a marca do meu carro, a lista de compras que faço, o que costumo beber e quanto pago de imposto, você terá a mim: uma unidade demográfica composta de uma só pessoa.

Essa argumentação, entretanto, ignora a diferença fundamental existente entre a transmissão voltada para grupos específicos de interesse - ou seja, o narrowcasting - e âmbito digital. Sendo digital, eu sou eu mesmo, e não um subconjunto estatístico. Ser eu mesmo é algo que pressupõe informações e acontecimentos desprovidos de qualquer significado demográfico ou estatístico. Onde mora minha sogra, com quem jantei a noite passada, e a que horas meu vôo parte para Richmond esta tarde são dados que não possuem qualquer correlação ou base estatística que possa dar origem a serviços apropriados de narrowcasting (NEGROPONTE, 1995, p. 144). 
Pontos a destacar no que diz respeito à educação audiovisual:

a) a formação de acervos em suporte material (película, videocassete, DVD, Blu-Ray), que configura necessidade de investimentos por redes de ensino e escolas para a prática da educação audiovisual, já não é mais indispensável, embora parcela da produção - sobretudo a convencional, que depende, em maior ou menor grau, das receitas aferidas na distribuição - ainda não esteja disponível em acervos digitais on line;

b) o acesso aos acervos digitais on line deve ser disseminado na escola não só porque facilita a exibição de obras, mas também porque representa um dos aspectos inclusivos, em termos culturais, sociais, políticos e econômicos, das novas tecnologias.

\subsection{Diretrizes educacionais brasileiras}

\subsubsection{Ensino Fundamental}

Em julho de 2004, o Departamento de Políticas de Educação Infantil e Ensino Fundamental do Ministério da Educação divulgou o documento "Ensino Fundamental de Nove Anos", com orientações gerais para a implantação do programa "Ampliação do Ensino Fundamental para Nove Anos". De acordo com a nomenclatura que se refere à ampliação (que havia sido determinada pela Lei $\mathrm{n}^{\circ}$ 10.172/2001), o Ensino Fundamental passou a ser subdividido em duas etapas: os Anos Iniciais, do primeiro ao quinto; e os Anos Finais, do sexto ao nono. $O$ ingresso do aluno ocorre aos seis anos de idade.

O documento reafirma princípios da Lei de Diretrizes e Bases da Educação Nacional, de 1996, como o de considerar que a escola seja um "polo irradiador de cultura e conhecimento" e que a educação, em 
concepção mais abrangente, corresponda aos "processos formativos que se desenvolvem na vida familiar, na convivência humana, no trabalho, nas instituições de ensino e pesquisa, nos movimentos sociais e organizações da sociedade civil e nas manifestações culturais" (p. 12).

São reafirmados, também, os objetivos do Ensino Fundamental de acordo com o art. 32 da Lei de Diretrizes e Bases da Educação Nacional:

I - o desenvolvimento da capacidade de aprender, tendo como meios básicos o pleno domínio da leitura, da escrita e do cálculo;

II - a compreensão do ambiente natural e social, do sistema político, da tecnologia, das artes e dos valores em que se fundamenta a sociedade;

III - o desenvolvimento da capacidade de aprendizagem, tendo em vista a aquisição de conhecimentos e habilidades e a formação de atitudes e valores;

IV - o fortalecimento dos vínculos de família, dos laços de solidariedade humana e de tolerância recíproca em que se assenta a vida social (p. 14).

O documento destaca, entre os "elementos importantes para a revisão da Proposta Pedagógica do Ensino Fundamental que incorporará as crianças de seis anos", os seguintes pontos das Diretrizes Curriculares Nacionais para a Educação Infantil, de 1998:

- As propostas pedagógicas [...] devem promover em suas práticas de educação e cuidados a integração entre os aspectos físicos, emocionais, afetivos, cognitivolinguísticos e sociais da criança, entendendo que ela é um ser total, completo e indivisível. [...]

- Ao reconhecer as crianças como seres íntegros que aprendem a ser e a conviver consigo mesmas, com os demais e com o meio ambiente de maneira articulada e gradual, as propostas pedagógicas [...] devem buscar a 
interação entre as diversas áreas do conhecimento e aspectos da vida cidadã como conteúdos básicos para a constituição de conhecimentos e valores. Dessa maneira, os conhecimentos sobre espaço, tempo, comunicação, expressão, a natureza e as pessoas devem estar articulados com os cuidados e a educação para a saúde, a sexualidade, a vida familiar e social, o meio ambiente, a cultura, as linguagens, o trabalho, o lazer, a ciência e a tecnologia.

- Tudo isso deve acontecer num contexto em que cuidados e educação se realizem de modo prazeroso, lúdico. Nesta perspectiva, as brincadeiras espontâneas, o uso de materiais, os jogos, as danças e os cantos, as comidas e as roupas, as múltiplas formas de comunicação, de expressão, de criação e de movimento [...] devem estar contempladas (p. 14-15).

O documento mantém intocadas as Diretrizes Curriculares Nacionais para o Ensino Fundamental, de 1988, que estabelecem, entre os princípios alinhados no parecer que thes deu origem:

III - As escolas deverão reconhecer que as aprendizagens são constituídas na interação entre os processos de conhecimento, linguagem e afetivos, como consequência das relações entre as distintas identidades dos vários participantes do contexto escolarizado, através de ações inter e intra-subjetivas; as diversas experiências de vida dos alunos, professores e demais participantes do ambiente escolar, expressas através de múltiplas formas de diálogo, devem contribuir para a constituição de identidades afirmativas, persistentes e capazes de protagonizar ações solidárias e autônomas de constituição de conhecimentos e valores indispensáveis à vida cidadã (p. 5).

As diretrizes estabelecem que o currículo do Ensino Fundamental terá uma Base Nacional Comum, reunindo conteúdos mínimos relacionados a áreas do conhecimento, e uma Parte Diversificada, que envolve conteúdos complementares "escolhidos por cada sistema de 
ensino e estabelecimentos escolares", de acordo com "as características regionais e locais da sociedade, da cultura, da economia e da clientela" (p. 6).

A Base Nacional Comum e a Parte Diversificada "deverão integrar-se em torno de paradigma curricular", que visa a estabelecer a relação da Educação Fundamental com a "Vida Cidadã" e com as "Áreas do Conhecimento". O documento relaciona à "Vida Cidadã", entre os "vários dos seus aspectos":

1. a Saúde;

2. a Sexualidade;

3. a Vida Familiar e Social;

4. o Meio Ambiente;

5. o Trabalho;

6. a Ciência e a Tecnologia;

7. a Cultura;

8. as Linguagens (p. 7).

Pontos a destacar no que diz respeito à educação audiovisual:

a) as diretrizes para o Ensino Fundamental de nove anos preveem a presença do audiovisual no âmbito de aspectos da "Vida Cidadã" - a cultura e a linguagem -, atribuindo ao projeto políticopedagógico de cada escola a adoção, na Parte Diversificada, de programas que o contemplem;

b) o audiovisual pode ser usado também como instrumento de apoio à "interação entre os processos de conhecimento, linguagem e afetivos", para trabalhar "as diversas experiências de vida dos alunos, professores e demais participantes do ambiente escolar" e para auxiliar na constituição de "identidades afirmativas".

\subsubsection{Ensino Médio}


Em setembro de 2009, a Diretoria de Concepções e Orientações Curriculares da Secretaria de Educação Básica do Ministério da Educação divulgou a versão final ${ }^{53}$ do documento orientador "Ensino Médio Inovador", dirigido às Secretarias Estaduais de Educação e do Distrito Federal. 0 documento reúne "pressupostos que indicam a necessidade de estabelecimento de políticas educacionais para os adolescentes e jovens", segundo parâmetros sobre organização curricular "adequados às perspectivas da sociedade moderna", e relaciona aspectos organizacionais do programa, que "converge para o apoio técnico e financeiro ao desenvolvimento de projetos que visem o aprimoramento de propostas curriculares" capazes de "disseminar nos respectivos sistemas a cultura de um currículo dinâmico, flexível e compatível com as exigências da sociedade contemporânea" (p. 3).

De acordo com o programa, o Ensino Médio "deverá estruturarse em consonância com o avanço do conhecimento científico e tecnológico, fazendo da cultura um componente da formação geral, articulada com o trabalho produtivo" (p. 4). Sua perspectiva de organização curricular "pressupõe a possibilidade de articulação interdisciplinar voltada para o desenvolvimento de conhecimentos -saberes, competências, valores e práticas". Dentro de um processo "dinâmico, participativo e contínuo", propõe-se o estímulo a "novas formas de organização das disciplinas articuladas com atividades integradoras, a partir das inter-relações existentes entre os eixos constituintes do ensino médio, ou seja, o trabalho, a ciência, a tecnologia e a cultura" (p. 7).

Cabe deter-se em como a definição de cultura encampa naturalmente $\mathrm{o}$ audiovisual:

${ }^{53}$ Uma versão preliminar do documento foi divulgada em abril de 2009. 
A cultura deve ser entendida como as diferentes formas de criação da sociedade, seus valores, suas normas de conduta, suas obras. Portanto, a cultura é tanto a produção ética quanto estética de uma sociedade; é expressão de valores e hábitos; é comunicação e arte. Uma formação que não dissocie a cultura da ciência e do trabalho possibilita aos estudantes compreenderem que os conhecimentos e os valores característicos de um tempo histórico e de um grupo social trazem a marca das razões, dos problemas, das necessidades e das possibilidades que orientaram o desenvolvimento dos meios e das relações de produção de um determinado sentido (p. 8).

Entre os indicativos para o projeto político-pedagógico de cada unidade escolar, com o objetivo de promover "o entrelaçamento entre trabalho, ciência e cultura", figuram diretrizes que também favorecem a integração do audiovisual à escola:

- Contemplar atividades integradoras de iniciação científica e no campo artístico-cultural;

$[\ldots]$

- Articular teoria e prática, vinculando o trabalho intelectual com atividades práticas experimentais;

- Utilizar novas mídias e tecnologias educacionais, como processo de dinamização dos ambientes de aprendizagem;

[...]

- Promover atividades sociais que estimulem o convívio humano e interativo do mundo dos jovens;

$[\ldots]$

- Organizar os tempos e os espaços com ações efetivas de interdisciplinaridade e contextualização dos conhecimentos;

[...]

- Ofertar atividades de estudo com utilização de novas tecnologias de comunicação;

[...] (pp. 9-10). 
Pontos a destacar no que diz respeito à educação audiovisual:

a) o Programa "Ensino Médio Inovador" prevê a presença da cultura audiovisual de maneira objetiva em suas diretrizes, determinando sua incorporação ao projeto político-pedagógico de cada escola;

b) o audiovisual pode ser usado também como instrumento de apoio a diretrizes que não o contemplam explicitamente, como a promoção de atividades sociais que estimulem o convívio humano e interativo do mundo dos jovens. 


\section{Princípios, competências e eixos temáticos}

A proposta de curso de especialização voltado à formação de professores para a educação audiovisual apresentada neste trabalho pauta-se pelos seguintes princípios:

a) entende-se por produção audiovisual, à qual se refere a educação audiovisual, o amplo universo que engloba obras produzidas originalmente para exibição no circuito cinematográfico e nos canais abertos e pagos da televisão, bem como obras realizadas em qualquer suporte, com o uso da linguagem audiovisual, para circulação em outros meios, como sítios da internet e aparelhos portáteis (telefones celulares, tocadores de MP4, tablets, consoles de videogame) $)^{54}$;

b) a educação audiovisual no âmbito da Educação Básica pode ocorrer de acordo com diferentes modalidades, não exclusivas e preferencialmente complementares: como instrumento paradidático em aulas e demais atividades de disciplinas curriculares; em forma de disciplina ou de projeto interdisciplinar ou multidisciplinar; como atividade extracurricular, em forma de disciplina optativa ou projeto, inclusive se realizado, em parte ou integralmente, fora da própria escola, desde que a atividade esteja integrada a um plano pedagógico;

c) a plenitude da educação audiovisual envolve, de maneira integrada, a alfabetização para os meios $e$ a expressão por meio de imagens e sons, implicando a prática da realização;

d) a alfabetização para os meios atinge seu objetivo quando o aluno aprende a trabalhar com as linguagens e com os mecanismos de

\footnotetext{
54 Para a fundamentação que sustenta a constituição desse campo a partir da aproximação entre o cinema e a televisão, cf. GIACOMANTONIO, 1976, e SILVA; ROSSINI, 2009.
} 
produção de sentido neles implicados, discernindo, para efeito de leitura crítica e de realização, que obras audiovisuais correspondem a representações subjetivas do mundo, e não ao próprio mundo;

e) ações de educação audiovisual devem ser inseridas, preferencialmente, em contextos escolares nas quais sejam desenvolvidas também atividades pedagógicas em outros campos da comunicação social e das artes, de modo a integrar-se a elas de maneira complementar, e não se estabelecer isoladamente;

f) o campo da educação audiovisual vem se estruturando de forma independente ao da arte-educação e ao da educomunicação ${ }^{55}$, embora apresente com ambos intersecções: com o primeiro, pela contribuição do cinema, sobretudo, ao estudo das artes visuais, e mais recentemente pela incorporação do cinema e do vídeo a instalações e obras interativas expostas em galerias, museus e outros espaços públicos ${ }^{56}$; com o segundo, pelo fato de a televisão figurar entre os meios de comunicação de massa e ser contemplada, ao lado dos veículos impressos e do rádio, em práticas educomunicativas de leitura crítica e de produção;

g) a justificativa para o estudo autônomo da educação audiovisual está relacionada à especificidade da história e da linguagem da produção audiovisual em relação ao campo das artes e ao dos meios

\footnotetext{
55 A educomunicação divide-se em três áreas: a da mediação tecnológica na educação (information literacy), que envolve o uso de ferramentas de informação em processos educativos, presenciais ou não; a da educação para a comunicação, ou educação para os meios (media literacy), que envolve estudos de recepção; e a da gestão comunicativa, voltada para o planejamento e a execução de políticas de comunicação educativa (Cf. SOARES, 2003). Para uma delimitação do campo da educação para os meios, apresentação de justificativas, estratégias para alfabetização midiática em sala de aula e tendências diante da inserção da escola na "revolução digital", cf. BUCKINGHAM, 2003.

${ }^{56}$ Para a análise das relações entre o cinema e as artes visuais, e para o fenômeno contemporâneo dos "transcinemas", conceito aplicado a imagens que geram ou criam uma nova construção do espaço-tempo cinematográfico, em que a presença do "participador" (espectador atuante) ativa a trama desenvolvida, cf. MACIEL, 2009.
} 
de comunicação de massa, bem como à organização socioeconômica de suas manifestações, inclusive no campo acadêmico brasileiro, em que os cursos para a formação de seus profissionais se apresentam em graduações autônomas;

h) a formação para a educação audiovisual deve ser feita de acordo com as especificidades da própria educação audiovisual, recorrendo intensa e regularmente a atividades de leitura crítica do audiovisual, promoção de debates, pesquisa e realização audiovisual.

De acordo com os princípios acima relacionados, as principais competências a serem desenvolvidas são:

a) familiaridade com os conhecimentos do campo de estudos sobre o audiovisual e a educação, para o planejamento pedagógico, a supervisão, a execução e a avaliação de projetos e ações nessa área;

b) capacidade de exercício da crítica da produção audiovisual e do entendimento de seus mecanismos de representação do mundo, bem como de suas reverberações políticas e econômicas;

c) capacidade de mediação de atividades escolares realizadas com o uso do audiovisual, com destaque para a criação e a administração de mediatecas, a utilização de acervos já estabelecidos, a realização de aulas e debates, e a curadoria de eventos;

d) capacidade de promover e supervisionar a realização audiovisual, por estudantes, na escola.

Pretende-se, com o curso, possibilitar ao professor de Educação Básica um processo de imersão profunda na cultura do audiovisual; e, por meio dessa imersão, facilitar o entendimento de como ele pode se relacionar, de modo ativo e crítico, com a produção audiovisual contemporânea.

Para que seja possível desenhar uma grade curricular em consonância com esses objetivos, cabe estabelecer, por meio de eixos 
temáticos, quais seriam os horizontes de conteúdo a serem trabalhados.

Esses eixos - cada um dos quais pode, por sua vez, dar origem a cursos de formação menos abrangentes, promovidos por redes de ensino, escolas ou outras instituições compromissadas com a qualificação do professor de Educação Básica - estariam assim organizados:

a) história da educação audiovisual;

b) leituras do audiovisual;

c) política e economia do audiovisual;

d) audiovisual e cibercultura;

e) estratégias de educação audiovisual.

A seguir, as justificativas para a delimitação dos eixos e a configuração de conteúdos a serem trabalhados em cada um deles.

\subsection{História da educação audiovisual}

Este eixo ocupa-se do estudo das relações entre o audiovisual e a educação ao longo do século XX e na primeira década do século XXI, de forma a estabelecer relações entre os contextos, em cada um desses campos, que levaram à formulação de propostas para aproximálos. Supõe-se, em curso de formação de professores da Educação Básica, que tenham sido trabalhados, nas respectivas graduações e licenciaturas dos alunos, os conhecimentos referenciais sobre a história da pedagogia no período em que a educação formal, oferecida pela escola, passa a conviver socialmente com outra modalidade de educação, informal, representada pela produção audiovisual.

Dessa forma, o procedimento estratégico, nas disciplinas e atividades deste eixo, é o de sublinhar especialmente o que não tem 
sido contemplado pelas grades curriculares dos cursos de graduação que formam professores, ou seja, uma abordagem da história do audiovisual que possibilite compreender como a trajetória do cinema e da televisão, em especial, comunica-se com algumas das principais transformações sociais dos últimos cem anos, e qual a repercussão dessa presença ostensiva na vida de crianças e jovens. As propostas de Almeida, Rossellini, Peters e Ferrés, tratadas nos Capítulos 1 e 2, fornecem a estrutura para essa abordagem.

Este eixo dedica-se também a identificar as intersecções entre a educação audiovisual e a educomunicação, examinada a partir das contribuições pioneiras do francês Célestin Freinet (1896-1966), do brasileiro Edgard Roquette-Pinto (1884-1954) e dos argentinos Mario Kaplún (1923-1998) e Daniel Prieto Castillo. Práticas educomunicativas que se utilizam de meios impressos, como os projetos que preveem a produção de jornais por alunos ${ }^{57}$, ou do rádio, por intermédio da criação e manutenção de emissoras no ambiente escolar, podem ser aproximadas e contrastadas às práticas de educação audiovisual ${ }^{58}$. Nesse campo de estudos, foi desenvolvido o conceito de "ecossistemas comunicacionais"59, importante para caracterizar, na escola, a criação de condições favoráveis à implantação de projetos e à execução de ações relacionadas ao audiovisual.

As variantes identificadas por Kaplún nas estratégias de comunicação e educação, aplicadas tanto ao ensino formal quanto ao informal, correspondem também a possibilidades de desenvolvimento

\footnotetext{
${ }^{57}$ Para um detalhado programa de como inserir a mídia impressa na escola, cf. FARIA, 1996.

${ }^{58}$ Para um levantamento de experiências educomunicativas em desenvolvimento no Brasil, cf. REDE DE EXPERIÊNCIAS EM COMUNICAÇÃO, EDUCAÇÃO E PARTICIPAÇÃO, s/d, e VOLPI et al., 2010.

${ }^{59}$ Cf. SIERRA, 2000.
} 
da educação audiovisual. Na primeira e ainda hegemônica variante identificada, chamada "modelo de educação bancária", os procedimentos pedagógicos estão centrados unicamente no conteúdo e, dessa forma, a comunicação integra o arsenal de recursos didáticos que regulam o fluxo de informações em sala de aula. Estabelece-se, dessa forma, uma relação aluno-professor vertical e autoritária.

$\mathrm{Na}$ segunda o "modelo dos efeitos" mantém o viés positivista, pois, embora a ênfase no uso de recursos informatizados - em geral tratados como "novas tecnologias" - em sala de aula pareça conduzir a um entendimento das novas condições sociais de comunicação, ela continua a reforçar a concepção de educação meramente como um processo de transmissão de mensagens a uma audiência.

De acordo com a terceira variante identificada por Kaplún, o "modelo dialógico ou transformador", a educação para os meios transforma-se em processo gerador de sentido e prevê a organização de um sistema participativo e autônomo que inclua todas as modalidades possíveis de comunicação (individual, grupal, horizontal, vertical, oral, impressa, audiovisual, transversal) a partir da vivência dos conteúdos da educação.

A escola tradicional estruturou-se segundo lógica que lembra a do fordismo, industrial; a educomunicação e a educação audiovisual, desde que implantadas segundo os valores da terceira variante apontada por Kaplún, constituem instrumento para tentar, ainda que ligeiramente ou de maneira localizada, "desestruturá-la", ou seja, questioná-la, criticá-la (no sentido de colocá-la em crise) e movê-la na direção de práticas menos compartimentalizadas e articuladas em rede. Intersecções com o campo de estudos da arte-educação integram também o espectro de temas a serem trabalhados neste eixo. No Brasil, o trabalho pioneiro de Ana Mae Barbosa é referencial para o 
entendimento da importância da presença das artes na formação de crianças e jovens, e para a discussão de estratégias de sala de aula ${ }^{60} .0$ de Hernández (2000) corresponde também a um paradigma para o estudo da arte na Educação Básica com o objetivo de promover a compreensão da cultura visual, incluindo a defesa de um enfoque transdiciplinar que tanto pode abarcar a educação audiovisual como servir de referência a ela na adoção de abordagem semelhante. Em Perkins (1994) e Battut (2003), encontram-se detalhadas propostas metodológicas para o estudo da imagem que enfatizam a imersão dos alunos no universo da apreciação, simultaneamente à promoção de experiências de realização, como na educação audiovisual plena. A possível contribuição da arte-educação para o fortalecimento do projeto pedagógico na escola, em variação do conceito de "ecossistemas comunicacionais" aplicado ao campo das artes (em delimitação que inclui, além das artes visuais, a música, a dança, o teatro e a criação literária), é analisada, com base no estudo de projetos desenvolvidos no sistema educacional público dos EUA, em Fowler (1996) e Noblit (2009).

É preciso lembrar, no entanto, que essa discussão envolve o próprio status do cinema, sobretudo, no mundo contemporâneo:

Cinema, arte contemporânea: é, portanto, a um só tempo, uma questão de estética e uma questão de história. Foi por muito tempo, exclusivamente, a da relação do cinema com a arte; além do mais, privilegiaram-se, por muito tempo, respostas genéricas. Mas, enquanto o cinema for visto como uma superação ou um anexo da herança artística, ele não poderá se desenvolver como "arte contemporânea". Ora, nessa

\footnotetext{
60 Para uma análise do desenvolvimento do campo da arte-educação no Brasil, cf. BARBOSA, 2002, e BARBOSA, 2008; resumo das propostas metodológicas da autora é apresentado em BARBOSA, 2005.
} 
relação com o passado, não foi colocado um termo brutal; ela sobrevive em diversas formas, embora subvertidas pelo término de qualquer projeto ainda ligado à existência de uma arte identificável com base na pintura (ou seja, em qualquer projeto moderno). Daí a ambiguidade do cinema hoje, no momento de sua anexação galopante pelo museu de arte contemporânea (AUMONT, 2008, p. 79).

Neste eixo, cabe também o estudo do impacto psicológico das mídias sobre crianças e jovens, incluída a abordagem de um dos temais mais caros - e talvez o mais importante, ao lado da sedução para o ingresso na sociedade de consumo - à avaliação de boa parte do que a indústria cultural oferece para a fruição de crianças e jovens, a cultura da violência. Strasburger (1995) dedica atenção sobretudo à televisão e às mensagens publicitárias veiculadas nesse meio, detendo-se especialmente nos temas da violência, da sexualidade, das drogas e da nutrição. 0 impacto das imagens de violência no cinema é analisado por Mongin (1998), em abordagem - mais próxima à escola "apocalíptica" a que faz menção Ferrés, citando Eco - que privilegia os mecanismos pelos quais essas imagens produzem dessensibilização e catarse, enquanto Jones (2004) estende o alcance de sua análise - em abordagem mais próxima à "integrada", também na analogia de Ferrés à conceituação de Eco - aos videogames, entendidos como manifestação contemporânea da necessidade infantil de mesclar a experiência do mundo concreto com a remissão a universos fabulares e de fantasia. Os videogames constituem, ao lado do cinema e da televisão, o objeto de pesquisa de Bazalgette (1995), que se volta exclusivamente para a indústria do entretenimento dos EUA - o que, vale dizer, o aproxima do mercado de entretenimento infanto-juvenil brasileiro, em que circulam majoritariamente produtos da indústria cultural dos EUA, como os originados no grupo Disney. 


\subsection{Leituras do audiovisual}

As disciplinas e atividades deste eixo privilegiam a capacitação do professor para o exercício da crítica da produção audiovisual, o que envolve trabalhar elementos de linguagem e procedimentos de análise com alunos que, ao menos em seus cursos de formação como professores, não foram apresentados a esses conhecimentos, não previstos entre os conteúdos da graduação em Pedagogia e das licenciaturas. Jullier (2009) fornece, aplicada ao campo do cinema, abordagem exemplar, porque utiliza exemplos do repertório popular e soa amistosa a não iniciados. A partir de longas-metragens pertencentes à cultura de massas, são analisados elementos de linguagem nos níveis do plano, da sequência e do filme.

As ferramentas de análise fílmica utilizadas por esse método empírico são aplicadas a títulos representativos do cinema silencioso, do período de consolidação dos gêneros industriais, do modelo narrativo clássico, do cinema moderno e da era pós-moderna. A apresentação das teorias do cinema encontra igualmente nas abordagens de Andrew (1989), Stam (2003) e Aumont (2004) modalidade didática e amistosa de imersão no tema, articulando visão panorâmica que cumpre também, em sua organização cronológica, o objetivo de estabelecer conexões com pontos nevrálgicos na história cinematográfica.

A capacitação para a leitura crítica da programação televisiva toma como referência, para a dimensão ficcional, a análise de Balogh (2002), que possibilita a discussão de gêneros e formatos aplicada a repertório de intensa presença na sociedade brasileira, composto pelas telenovelas e pelas minisséries. A abordagem de Machado (2001) 
funciona de modo complementar, ao eleger um repertório referencial os "trinta programas mais importantes da história da televisão" - que contempla, além da ficção, o telejornalismo e o videoclipe. Aspectos de caráter ideológico sobre o meio são incorporados a exercícios de análise de sua programação por Ferrés (1996), Martín-Barbero (2001) e Jost (2004). A produção em vídeo e sua posterior confluência com o cinema e a televisão no espectro mais amplo da produção audiovisual têm seus elementos estéticos em plena mutação abordados por Machado (1988), Aristarco (1990) e Nunes (1996).

Não se deve perder de vista, contudo, o fato de a leitura crítica da programação da TV exigir que se faça análise cuidadosa do próprio meio e de sua inserção na sociedade:

[...] temos a impressão de que não há mais uma linha diretriz para orientar as quatro grandes transformações em curso: a mudança de técnica com uma multiplicação e diversificação dos canais, a mudança política com a privatização e 0 desvinculamento do Estado $^{61}$, a mudança econômica com a constituição de grandes grupos, a mudança de público que exige, mais e mais, imagens.

0 que é fundamentalmente a televisão? Imagens e laço social. 0 divertimento e o espetáculo remetem à imagem, isto é, à dimensão técnica. $\mathrm{O}$ laço social remete à comunicação, isto é, à dimensão social. Tal é a unidade teórica da televisão: associar duas dimensões, a técnica e a social, que [...] estão na origem de duas grandes ideologias que traduzem, ambas, uma desproporção no acerto de contas das duas dimensões. A ideologia técnica superestima o papel do instrumento; a ideologia política, ao contrário, superestima o papel que podemos fazê-la desempenhar. A história da televisão é a história da alternância, segundo a época, de uma ou de outra dessas ideologias (WOLTON, 1996, p. 12).

\footnotetext{
${ }^{61}$ Nesse aspecto, o autor se refere a transformações no cenário televisivo europeu na década de 1990.
} 
Três temas transversais são objeto de estudos neste eixo, dada a sua importância para o desenvolvimento de leitura crítica da produção audiovisual contemporânea: documentário, autoria e representação.

Para a apresentação dos conceitos que definem o documentário como produção audiovisual de não ficção e, também, para a compreensão das dificuldades para o estabelecimento de fronteiras rígidas entre a produção ficcional e a documental, sobretudo no cenário da produção contemporânea, marcada por intenso hibridismo, são fundamentais as abordagens de Nichols (2005), Ramos (2008) e, em especial, Comolli (2008), cujo percurso de análise transpõe divisas formais entre o cinema, a televisão e o vídeo, e também entre a ficção e o documentário, para se ocupar das relações entre o estatuto da imagem em movimento e a realidade, tópico estratégico para a educação cinematográfica.

As abordagens que sustentam o conceito de autor no cinema - a "política dos autores" apresentada pelos críticos da revista francesa Cahiers du Cinéma nos anos 1950, sua contrapartida norte-americana, defendida pelo crítico Andrew Sarris no início dos anos 1960, e o estruturalismo autoral, combinando referências da filosofia, da psicanálise e da semiótica ${ }^{62}$ - podem ser trabalhadas a partir de Bernardet (1991, 1994). Nogueira (2002) trata da possibilidade de aplicar o conceito de autoria à TV, com base em análise da obra do escritor de telenovelas brasileiro Gilberto Braga.

\footnotetext{
62 Para introdução a cada uma dessas abordagens e aplicação de seus princípios e métodos em obra voltada à formação em educação cinematográfica e publicada pelo British Film Institute, cf. WHARTON (2005).
} 
A abordagem dos mecanismos de representação utilizados pela produção audiovisual enfatiza, neste eixo, uma área de especial interesse para a Educação Básica: a da representação da História. Parcela significativa da presença do audiovisual na escola envolve, como instrumento paradidático, a exibição de filmes para cinema (ficção e documentários) e programas variados produzidos para a TV sobre personagens e eventos históricos presentes no conteúdo de diversas disciplinas. O estudo dos mecanismos de representação é imprescindível para que se evite o uso muitas vezes ingênuo (que considera o audiovisual registro objetivo e inquestionável da História) e limitador das possibilidades de entendimento da representação audiovisual como elemento bibliográfico ou mesmo, em determinadas circunstâncias, como documento de relevância histórica que expõe as condições de produção e o entorno cultural da época em que foi realizado - e não apenas daquela que se busca representar.

A função didática da relação cinema-história se consubstancia na utilização de um novo método aplicado ao ensino: o uso da linguagem cinematográfica como instrumento auxiliar de formação histórica, com a finalidade de integrar, orientar e estimular a capacidade de análise dos estudantes. Do ponto de vista didático, trata-se de utilizar películas já existentes como fontes para a discussão de temas históricos, de analisar o cinema como agente da história e como documento e, mais ainda, de preparar estudantes para a pesquisa.

Sem dúvida alguma, a resistência para enxergar no filme, histórico ou não, um instrumento didático da maior eficácia é ainda muito grande. Isto ocorre por várias razões que encontram no imobilismo conservador das instituições acadêmicas um terreno fértil. A escola e a universidade acompanham, com dificuldade, a revolução tecnológica processada durante a contemporaneidade (NÓVOA, 2008, p. 34). 
Essa abordagem do audiovisual como documento e como agente da História é adotada por Ferro (2010), Rosenstone (2010) e pelos ensaios reunidos em Capelato et al (2007). Cabe, no estudo do tema, abordar as relações entre o audiovisual e a História no âmbito de ações afirmativas, como a determinada pela Lei $n^{\circ} 10.639 / 2003$, que torna obrigatória a temática "História e Cultura Afro-Brasileira" no currículo da Educação Básica. Souza $(2006,2007)$ ocupa-se desse recorte.

Este eixo tem seu conteúdo aplicado, na estruturação do curso de especialização, por meio de um laboratório de produção crítica que se estende por toda a formação, e cujos exercícios devem combinar a produção de textos e a apresentação oral e audiovisual das leituras realizadas, de modo a exercitar a crítica em todas as formas de expressão mobilizadas por atividades de caráter analítico em ações de educação audiovisual (escrita, aulas expositivas, mediação de debates, realização).

\subsection{Política e economia do audiovisual}

Neste eixo, trabalha-se a compreensão da dimensão política e econômica do audiovisual na sociedade contemporânea, com suas implicações ideológicas. Assim, parte-se da estruturação da atividade cinematográfica, ainda na virada do século XIX para o século XX, sobre três pilares - produção, distribuição e exibição - e da relação simbiótica entre seus respectivos agentes, sem a qual a chegada de uma obra ao mercado (e, portanto, ao público) enfrenta imensas dificuldades, ou mesmo não se concretiza. Esse tripé determina ainda hoje como se desenvolve o negócio do cinema em escala planetária, com ampla 
hegemonia da indústria dos EUA - também composta, no entanto, por conglomerados de capital multinacional ${ }^{63}$.

Ao produzir obras voltadas para o consumo de espectadores culturalmente distintos em mercados espalhados por todos os continentes, a expansão da atividade cinematográfica sob controle de Hollywood - cuja identidade se confunde com a da indústria norteamericana - deu-se ao longo do século XX de acordo com princípios da economia globalizada, que favorecem os tentáculos corporativos de presença e ação transnacionais, em detrimento de agentes locais.

Essa aproximação permite compreender as dificuldades enfrentadas pelos cinemas de muitos países -- entre eles, o Brasil ${ }^{64}$-para fazer frente à entrada em seus mercados de obras norteamericanas e à disputa de espectadores em condições desfavoráveis, levando à criação de modelos de financiamento da produção baseados em incentivos fiscais e na atuação direta do Estado, que se estende também, por meio de benefícios diretos ou indiretos, a intervenções nas esferas de distribuição e exibição ${ }^{65}$.

Filmes, no mundo todo, são produzidos pelas mesmas companhias envolvidas com outras atividades de mídia e comunicação; e não é segredo que cada vez menos corporações controlam estas atividades. Como em tantos outros setores industriais, os processos de concentração e "comodificação" também ocorrem na indústria cinematográfica mundial. Detalhar como as indústrias manufaturam commodities dentro de um sistema capitalista é um importante elemento para

\footnotetext{
${ }^{63}$ Para compreensão de como se estruturam hoje as grandes corporações dos EUA que atuam na indústria do audiovisual e do entretenimento, cf. EPSTEIN, 2005.

64 Para análise atualizada do impacto provocado no Brasil pela presença de grupos estrangeiros na distribuição e exibição cnematográficas, cf. SILVA, 2010.

65 Para um histórico das políticas de Estado implementadas no Brasil com o objetivo de regular e fomentar o mercado cinematográfico, cf. MARSON, 2009, e MELEIRO, 2009a, 2009b.
} 
entender as imagens em movimento neste século (MELEIRO, 2007, p. 14).

Um dos desdobramentos dessa análise conduz à importância estratégica de políticas de formação de público, com as quais a educação audiovisual guarda relação direta. Outra decorrência do predomínio da obra estrangeira no mercado doméstico é também cara à educação audiovisual, pois interfere na construção de repertório, no desenvolvimento de critérios de apreciação e, de modo geral, na adoção de valores socioculturais.

Bernardet (2009) propõe que a compreensão da trajetória do desenvolvimento do cinema brasileiro seja feita com base no fenômeno da dependência econômica externa:

Não é possível entender qualquer coisa que seja no cinema brasileiro, se não se tiver sempre em mente a presença maciça e agressiva, no mercado interno, do filme estrangeiro, importado quer por empresas brasileiras, quer por subsidiárias de produtores europeus e norte-americanos. Essa presença não só limitou as possibilidades de afirmação de uma cinematografia nacional como condicionou em grande parte suas formas de afirmação (BERNARDET, op. cit., p. 21).

Em relação a esse tema, cabe o contraste com a televisão brasileira, na qual a produção nacional tem presença proporcionalmente muito maior do que no cinema, inclusive por questões de regulamentação. Conhecimentos sobre a legislação das telecomunicações no Brasil possibilitam entender, em contexto mais amplo, como vem se organizando o campo da televisão no país, com o predomínio de grupos privados que atuam, em canais abertos, graças a concessões públicas, e como esse desenho de mercado, de 
concentração de capital nas mãos de poucos agentes, tem contribuído historicamente para favorecer certos gêneros e formatos. Assim como em relação ao cinema, é preciso dedicar atenção, neste eixo, às perspectivas abertas com a "revolução digital", sobretudo em relação à TV digital e interativa, e à possibilidade de contemplar políticas de inclusão social que envolvem, entre outros aspectos, a pulverização dos centros de produção e a adoção de mecanismos mais democráticos de programação ${ }^{66}$.

\subsection{Audiovisual e cibercultura}

O conceito de cibercultura ${ }^{67}$ e a análise da circulação da produção audiovisual pelas novas mídias, sobretudo as redes sociais criadas na internet, constituem o objeto deste eixo. A criação de identidade virtual e os hábitos de comunicação digital são indispensáveis para compreender o comportamento social de professores e de alunos, bem como as novas relações de ensinoaprendizagem, alterando antigos parâmetros de inserção do audiovisual no ambiente escolar e criando a perspectiva de novos usos. A cibercultura amplia a noção de "ecossistemas comunicacionais" - e talvez obrigue mesmo a formulação de nova definição, de caráter menos físico e muito mais virtual, do conceito.

As mudanças comportamentais provocadas pela cibercultura trazem novos desafios aos estudos sobre o impacto das mídias na vida de crianças e jovens, como observa a norte-americana Ellen Wartella:

\footnotetext{
${ }^{66}$ Para análise de como a indústria cinematográfica tem sido afetada pela "revolução digital", cf. DE LUCA, 2009, e GASPARD, 2010; para o impacto sobre a televisão, cf. CANNITO, 2010.

${ }^{67}$ Conjunto de técnicas (materiais e intelectuais), de práticas, de atitudes, de modos de pensamento e de valores desenvolvidos no ciberespaço, que corresponde a toda estrutura virtual transnacional de comunicação interativa. Cf. LEVY, 2009.
} 
Ao olharmos para o futuro, fica claro que as tecnologias interativas e digitais como a internet, telefones celulares e iPods trouxeram aos estudos questões relacionadas a como as crianças e os jovens utilizam as mídias (com que frequência e com que impacto sobre o usuário e a família). Também há novas questões sobre o poder de um mundo com uma mídia com transmissão em rede, em que as crianças e os jovens têm maior intervenção e controle do conteúdo, e qual sua resposta a isso. 0 poder da interatividade e da transmissão em rede ainda não está bem compreendido. Além do mais, não está totalmente claro para mim se estas novas mídias irão desafiar algum dos entendimentos fundamentais [...] sobre jovens e mídia: o de que as crianças são um público especial diferente dos adultos, com necessidades especiais nas diferentes idades, e que $o$ conteúdo importa. E como estas mídias poderiam ter influência sobre a vida real destas crianças no mundo todo - elas podem ser utilizadas para melhorar a saúde e o bem-estar das crianças? (In MAZZARELLA, 2009, p. 19).

Outro tema emergente de pesquisas sobre o audiovisual na cibercultura está relacionado à subjetividade e aos modos de enunciação:

[...] os novos meios que surgiram depois do cinema estimularam apenas poucas reflexões relacionadas ao modo como a subjetividade é neles construída e, por consequência, uma teoria da enunciação não foi jamais formulada nos ambientes pós-cinematográficos (televisão e vídeo), pelo menos não de forma tão sistemática como o foi na literatura e no cinema.

[...] No entanto, os novos meios que começaram a tomar forma depois da hegemonia da televisão, sobretudo os de natureza digital (hipermídia, realidade virtual, videogames, ambientes colaborativos baseados em rede etc.), restituíram a questão da inserção subjetiva e o fizeram de uma forma tão marcante, que chega a ser surpreendente o fato de não ter sido ainda 
formulada uma teoria da enunciação em ambientes digitais (MACHADO, 2007, p. 135).

Na era que chama de "hipermoderna", Lipovetsky (2009) propõe ainda outros temas de estudo para este eixo, relacionados aos conceitos de hipercinema e de cinevisão do mundo. O primeiro, relacionado a um novo estatuto de modernidade do cinema, refere-se à produção audiovisual na sociedade contemporânea, lançada a uma espiral hiperbólica nas esferas da tecnologia, da vida econômica, social e individual, em vertiginosa trajetória de extremos, "sem limite". 0 segundo conceito envolve a percepção de que o cinema não mostra apenas outro mundo, o do sonho e do irreal, mas o mundo em que vivemos transformado em misto de real e de imagem-cinema, "um real fora-do-cinema submetido ao molde do imaginário-cinema" produzindo, portanto, sonho e realidade, remodelada pelo espírito do cinema, mas não propriamente irreal.

Este eixo também se ocupa de outra dimensão das relações entre o audiovisual e a cibercultura: a incorporação do ciberespaço como argumento e como tema referencial em obras recentes realizadas, principalmente, para cinema, como analisa Felinto (2010).

\subsection{Estratégias de educação audiovisual}

O objetivo deste eixo é capacitar para o planejamento e a execução de diferentes modalidades de educação audiovisual no âmbito da Educação Básica:

a) como instrumento paradidático em aulas e demais atividades de disciplinas curriculares, com o objetivo de apresentar, contextualizar e problematizar aspectos de conteúdo programático; 
b) em forma de disciplina, dedicada de maneira mais ampla ao audiovisual, ou ainda, de modo mais restrito, apenas ao cinema e/ou à TV, para trabalhar conteúdos históricos, de linguagem, de leitura crítica e/ou de realização;

c) em forma de projeto interdisciplinar ou multidisciplinar, mobilizando a produção audiovisual, no âmbito da leitura crítica e/ou da realização, para integrar-se a disciplinas curriculares de acordo com objetivos propostos no plano pedagógico da escola;

d) como atividade extracurricular, em forma de disciplina optativa - contemplando o audiovisual ou, de modo mais restrito, o cinema e/ou a TV - ou projeto de exibição, de leitura crítica e/ou de realização, e de criação de comunidades de espectadores, inclusive se promovido, em parte ou integralmente, fora da própria escola, desde que corresponda ao proposto no plano pedagógico da unidade.

Conceitos e práticas de programação, de formação de (e acesso a) acervos, de planejamento de infraestrutura técnica, de mediação, de mobilização de redes sociais e de supervisão de produção serão exercitados a partir de estudos de caso e de laboratório de planejamento. Cabe detalhar, como tópico de relevância estratégica para a educação audiovisual plena, a capacitação para atividades de realização executadas por crianças e jovens.

\subsubsection{Realização audiovisual na escola}

A realização audiovisual possibilita, no âmbito da educação audiovisual plena:

a) o desenvolvimento, no campo das linguagens, da capacidade de expressão por meio de imagens e sons; 
b) a compreensão mais aguda de fatores relacionados à leitura crítica da produção audiovisual, por meio do conhecimento aplicado dos mecanismos de realização e de produção de sentido, evitando que se conformem com a perspectiva de serem apenas receptores passivos;

c) a mobilização, em virtude do trabalho em equipe, de elementos relacionados a processos de sociabilização, de comunicação interpessoal, de protagonismo, de empreendedorismo e de formação cidadã;

d) a mobilização em torno de pontos do conteúdo programático, trabalhados por meio da pesquisa necessária à realização audiovisual;

e) a promoção de estratégias de intervenção, na escola e em sua comunidade, por meio da realização, da exibição e do debate de obras produzidas pelos alunos, criando espaços para diálogo e instâncias de desconstrução das relações de poder;

f) o desenvolvimento de políticas inclusivas ${ }^{68}$;

g) a familiaridade com a tecnologia, cujo uso tornou-se indispensável no mundo do trabalho e no cotidiano social.

Neste eixo, os conceitos e as práticas envolvidos nas etapas de realização - argumento e roteiro, pré-produção, produção e pósprodução - e de difusão - exibição pública, promoção de debates - são trabalhados com ênfase nas oportunidades e nos desafios do trabalho com crianças e jovens. A necessária supervisão não pode lhes retirar a autonomia, sem a qual a produção escolar deixa de ser feita por eles, e passa a ser feita com eles.

$68 \mathrm{O}$ art. 13 da Convenção sobre os Direitos da Criança, adotada em Assembleia das Nações Unidas em 1989, determina que "a criança terá o direito à liberdade de expressão", e que esse direito "incluirá liberdade para procurar, receber e partilhar informações e ideias de todos os tipos, independentemente de fronteiras, oralmente, por escrito ou na forma impressa ou de arte, ou através de qualquer outro meio de escolha da criança". 
Os conhecimentos aplicados a serem trabalhados nestes eixos estão divididos pelas seguintes áreas:

a) tema, argumento e roteiro, com ênfase no formato curtametragem e na dramaturgia das micronarrativas e dos relatos autobiográficos, no domínio da ficção, e dos modos clássicos do documentário ${ }^{69}$, no domínio da não ficção;

b) pré-produção: story-board, roteiro técnico, direção e assistência de produção;

c) produção: operação de câmera e áudio, iluminação, recursos materiais e humanos, direção de atores, captação de depoimentos, realização de entrevistas, cessão de direito do uso de imagem;

d) pós-produção: edição, direitos autorais;

e) exibição: campanha para lançamento, promoção de debates, apreciação externa e autoavaliação do resultado.

${ }^{69}$ Há seis modos clássicos de documentário, de acordo com a tipologia de NICHOLS (2005): poético, expositivo, observativo, participativo, reflexivo e performático. 


\section{Objetivos, grade curricular e conteúdos}

A Câmara de Educação Superior do Conselho Nacional de Educação estabelece, na Resolução 1/2007, que os cursos de pósgraduação lato sensu -- entre os quais se incluem os de especialização -- oferecidos por instituições de educação superior devidamente credenciadas "são abertos a candidatos diplomados em cursos de graduação ou demais cursos superiores" (no Parágrafo 3 do Artigo 10.) e devem ter, tanto na modalidade presencial como os oferecidos a distância, "duração mínima de 360 (trezentas e sessenta horas)", não computado o tempo de estudo individual ou em grupo, sem assistência docente, e "o reservado, obrigatoriamente, para elaboração individual de monografia ou trabalho de conclusão de curso" (Artigo 5o.).

Em sintonia com essas diretrizes, o curso de especialização aqui proposto, na modalidade presencial ${ }^{70}$, tem duração superior à exigência mínima determinada pela Resolução acima, embora possa ser redimensionado para outra carga horária ${ }^{71}$, e organiza-se de acordo com os tópicos a seguir ${ }^{72}$.

\subsection{Objetivos}

\footnotetext{
${ }^{70}$ Para que pudesse ser oferecido a distância tal como se organiza nesta proposta, o curso de especialização em educação audiovisual precisaria sofrer ajustes, em especial, na dinâmica das atividades relacionadas à produção audiovisual na escola.

${ }^{71}$ Cf. Apêndice B.

72 Não estão apresentadas as informações diretamente relacionadas à política administrativa da instituição de ensino que oferece o curso de especialização, como pré-requisitos para inscrição, processo de seleção e normas de avaliação, entre outras exigências acadêmicas.
} 
O Curso de Especialização em Educação Audiovisual tem o objetivo de capacitar educadores para o trabalho com a produção audiovisual na Educação Básica, em suas diferentes modalidades, propiciando o desenvolvimento de conhecimentos teóricos e aplicados nesse campo de estudos para o planejamento pedagógico, a supervisão, a execução e a avaliação de projetos e ações. As disciplinas oferecidas contemplam: a) a leitura crítica da produção audiovisual e a compreensão de seus mecanismos de representação do mundo, bem como de suas dimensões políticas e econômicas; b) a mediação de atividades escolares realizadas com o uso do audiovisual, como a criação e a administração de mediatecas, a utilização de acervos, a realização de aulas e debates, e a curadoria de eventos; c) a promoção e supervisão da realização audiovisual, por estudantes, na escola.

\subsection{Perfil do aluno}

Professores e gestores da Educação Básica que sejam portadores de diploma de Ensino Superior, egressos dos cursos de graduação em Pedagogia e das licenciaturas, dos cursos de graduação em Audiovisual, profissionais desses e de outros campos do conhecimento que atuem ou planejem atuar, como multiplicadores ${ }^{73}$, no planejamento, na execução e na gestão de programas de capacitação de professores para o uso do audiovisual na escola.

\subsection{Metodologia}

\footnotetext{
73 A capacitação de multiplicadores, que possam trabalhar os conhecimentos do curso em atividades de qualificação para o audiovisual promovidas por suas redes de ensino ou pelas escolas onde trabalhem, tem importância estratégica para a difusão em maior escala da educação audiovisual.
} 
Aulas expositivas, exibições de obras audiovisuais, discussões em grupo, elaboração de textos reflexivos, exercícios de leitura crítica, de planejamento e de realização audiovisual, seminários, visitas a escolas e espaços culturais.

\subsection{Duração e carga horária}

A duração do curso é de três semestres, com carga horária total de 540 horas, das quais 450 horas em disciplinas ${ }^{74}, 60$ horas em atividades complementares ${ }^{75}$ e 30 horas para a orientação de monografia ou trabalho de conclusão de curso ${ }^{76}$.

\subsection{Programa}

As disciplinas estão organizadas de acordo com eixos de conteúdo e distribuídas em três módulos semestrais.

\footnotetext{
${ }^{74}$ Para que seja cumprida a carga horária de cada módulo semestral (150 horas), estimou-se que as aulas presenciais ocupem entre 16 e 17 semanas por semestre, à média de nove horas semanais, distribuídas por três dias. A determinação desses prazos, no entanto, depende do calendário letivo da instituição e da avaliação de qual o número de aulas semanais apropriado para o público do curso. Alguns cursos de especialização concentram as aulas semanais em um único dia (em geral, sábado).

${ }^{75}$ A estimativa é de 20 horas por módulo semestral.

${ }^{76}$ Como ocorre em cursos de especialização, a monografia ou trabalho de conclusão de curso pode ser entregue depois do encerramento dos três módulos semestrais, de acordo com prazos para depósito e defesa a serem estabelecidos pela instituição. É requisito indispensável, no entanto, para a efetiva conclusão do curso e obtenção de certificado.
} 
5.5.1. Organização por eixos temáticos

\begin{tabular}{|c|c|}
\hline $\begin{array}{l}\text { Eixos temáticos } \\
\text { (carga horária) }\end{array}$ & $\begin{array}{l}\text { Disciplinas } \\
\text { (carga horária) }\end{array}$ \\
\hline $\begin{array}{l}\text { História da educação } \\
\text { audiovisual (102) }\end{array}$ & $\begin{array}{l}\text { * Cinema, TV e educação (60) } \\
\text { * Mídia, infância e juventude (18) } \\
\text { * Fundamentos da educomunicação e } \\
\text { ecossistemas comunicacionais (24) }\end{array}$ \\
\hline $\begin{array}{l}\text { Leituras do } \\
\text { audiovisual } \\
\text { (96) }\end{array}$ & $\begin{array}{l}\text { * Fundamentos da crítica do audiovisual (24) } \\
\text { * Laboratório de crítica I (18) } \\
\text { * Laboratório de crítica II (18) } \\
\text { * Laboratório de crítica III (18) } \\
\text { * Audiovisual e representação (18) }\end{array}$ \\
\hline $\begin{array}{l}\text { Política e economia } \\
\text { do audiovisual ( } 30)\end{array}$ & * Política e economia do audiovisual (30) \\
\hline $\begin{array}{l}\text { Audiovisual e } \\
\text { cibercultura (42) }\end{array}$ & $\begin{array}{l}\text { * Ciberespaço, cibercultura e redes (30) } \\
\text { * Produção audiovisual e meios digitais (12) }\end{array}$ \\
\hline $\begin{array}{l}\text { Estratégias de } \\
\text { educação audiovisual } \\
(180)\end{array}$ & $\begin{array}{l}\text { * Planejamento pedagógico para a educação } \\
\text { audiovisual (45) } \\
\text { * Programação e mediação do audiovisual na } \\
\text { escola (45) } \\
\text { * Realização audiovisual I (30) } \\
\text { * Realização audiovisual II (30) } \\
\text { * Realização audiovisual III (30) }\end{array}$ \\
\hline
\end{tabular}


5.5.2. Organização por módulos semestrais

\begin{tabular}{|c|c|}
\hline $\begin{array}{c}\text { Módulos } \\
\text { semestrais } \\
\text { (carga horária) }\end{array}$ & Disciplinas (carga horária) \\
\hline Primeiro (150) & $\begin{array}{l}\text { * Cinema, TV e educação (60) } \\
\text { * Mídia, infância e juventude (18) } \\
\text { * Fundamentos da crítica do audiovisual (24) } \\
\text { * Laboratório de crítica I (18) } \\
\text { * Realização audiovisual I (30) }\end{array}$ \\
\hline Segundo (150) & $\begin{array}{l}\text { * Fundamentos da educomunicação e } \\
\text { ecossistemas comunicacionais (24) } \\
\text { * Audiovisual e representação (18) } \\
\text { * Política e economia do audiovisual (30) } \\
\text { * Ciberespaço, cibercultura e redes (30) } \\
\text { * Laboratório de crítica II (18) } \\
\text { * Realização audiovisual II (30) }\end{array}$ \\
\hline Terceiro (150) & $\begin{array}{l}\text { * Produção audiovisual e meios digitais (12) } \\
\text { * Planejamento pedagógico para a educação } \\
\text { audiovisual (45) } \\
\text { * Programação e mediação do audiovisual na } \\
\text { escola (45) } \\
\text { * Laboratório de crítica III (18) } \\
\text { * Realização audiovisual III (30) }\end{array}$ \\
\hline
\end{tabular}

5.6. Disciplinas

5.6.1. Cinema, TV e educação 
Objetivos:

Apresentar o campo de estudos sobre o audiovisual e a educação, analisando os contextos em que têm sido formuladas propostas para aproximar o cinema e a TV da Educação Básica.

\section{Programa:}

As contribuições de Joaquim Canuto Mendes de Almeida, Roberto Rossellini, Jan Marie Lambert Peters (em estudo para a Unesco), Joan Ferrés. Humberto Mauro e o Instituto Nacional de Cinema Educativo. O gênero educativo na programação da TV brasileira. Estudos de caso: a experiência britânica (o programa de educação audiovisual do British Film Institute), a experiência descentralizada francesa (planejamento e execução no âmbito autônomo de delegacias regionais de ensino). Intersecções com o campo de estudos da arte-educação.

Bibliografia:

ALMEIDA, Joaquim Canuto Mendes de. Cinema contra cinema: bases gerais para um esboço de organização do cinema educativo no Brasil. São Paulo: Companhia Editora Nacional, 1931.

BACCEGA, Maria Aparecida. Televisão e escola: uma mediação possível?. São Paulo: Senac, 2003.

BACHER, Silvia. Tatuados por los medios: dilemas de la educación en la era digital. Buenos Aires: Paidós, 2009.

BARBOSA, Ana Mae. Arte-educação no Brasil. São Paulo: Perspectiva, 2002.

CITELLI, Adilson (Org.). Outras linguagens na escola. São Paulo: Cortez, 2001.

DUARTE, Rosália. Cinema \& educação. Belo Horizonte: Autêntica, 2002.

FERRÉS, Joan. Televisão e educação. Porto Alegre: Artes Médicas, 1996.

Vídeo e educação. Porto Alegre: Artes Médicas, 1996.

FISCHER, Rosa Maria Bueno. Televisão \& educação: fruir e pensar a TV. Belo Horizonte: Autêntica, 2001. 
GUARNER, José Luis. Roberto Rossellini. Madri: Fundamentos, 1972

GUIMARÃES, Glaucia. TV e escola: discursos em confronto. São Paulo: Cortez, 2000.

MORAIS, Regis de. TV e educação: entre o caos e o horizonte. Campinas: Alínea, 2009.

PETERS, J. M. L. Teaching about the film: a Unesco study. Nova York: Columbia University Press, 1961.

PRIETO CASTILLO, Daniel. La televisión en la escuela -- Vol. 1 e 2. Buenos Aires: Lumen Humanitas, 1999.

ROSSELLINI, Roberto. Un espíritu libre no debe aprender como esclavo: escritos sobre cine y educación. Barcelona: Paidós, 2001. . Le cinéma révélé. Paris: Flammarion, 2008.

SALIBA, Maria Eneida Fachini. Cinema contra cinema: o cinema educativo de Canuto Mendes (1922-1931). São Paulo: Annablume/Fapesp, 2003.

SETTON, Maria da Graça Jacintho (Org.). A cultura da mídia na escola: ensaios sobre cinema e educação. São Paulo: Annablume: USP, 2004.

TAVARES, Clara Ferrão. A escola e a televisão: olhares cruzados. Lisboa: Plátano, 2004.

\subsubsection{Mídia, infância e juventude}

Objetivos:

Examinar como a trajetória do cinema, da televisão e de outras mídias de comunicação de massa impactou algumas das principais transformações sociais dos últimos cem anos, tornando-se presente no cotidiano de crianças e jovens, e interferindo em seu desenvolvimento.

Programa:

O impacto psicológico dos meios de comunicação de massa sobre crianças e jovens. Mecanismos de acesso e padrões de consumo. A produção audiovisual e o estímulo ao ingresso na sociedade de consumo. A cultura da violência no cinema, na TV, nos videogames e nos meios digitais. Tendências da produção audiovisual contemporânea 
dirigida a crianças e jovens. Modos de controle e regulamentação. Observatórios de mídia infanto-juvenil.

Bibliografia:

ACOSTA-ORJUELA, Guillermo Maurício. 15 motivos para "ficar de olho" na televisão. Campinas: Alínea, 1999.

BABIN, Pierre; KOULOUMDJIAN, Marie France. Os novos modos de compreender: a geração do audiovisual e do computador. São Paulo: Paulinas, 1989.

BAZALGETTE, Cary; BUCKINGHAM, David (Org.). In front of the children: screen entertainment and young audiences. Londres: British Film Institute, 1995.

BELLONI, Maria Luiza. A formação na sociedade do espetáculo. São Paulo: Edições Loyola, 2002.

- Crianças e mídias no Brasil: cenários de mudança. Campinas: Papirus, 2010.

CARLSSON, Ulla; FEILITZEN, Cecilia von. A criança e a mídia: imagem, educação, participação. São Paulo: Cortez; Brasília: Unesco, 2002.

FEILITZEN, Cecilia Von; BUCHT, Catharina. Perspectivas sobre a criança e a mídia. Brasília: Unesco, SEDH/Ministério da Justiça. 2002.

JONES, Gerard. Brincando de matar monstros: por que as crianças precisam de fantasia, videogames e violência de faz-de-conta. São Paulo: Conrad, 2004.

LARROSA, Jorge; CASTRO, Inês Assunção; SOUSA, José de (Org.). Miradas cinematográficas sobre la infancia: niños atravesando el paisaje. Buenos Aires: Miño y Dávila, 2007.

MAZZARELLA, Sharon R. (Org.). Os jovens e a mídia: 20 questões. Porto Alegre: Artmed, 2009.

MONGIN, Olivier. A violência das imagens: ou como eliminá-la? Lisboa: Bizâncio, 1998.

MORDUCHOWICZ, Roxana (Org.). Los jóvenes y las pantallas: nuevas formas de sociabilidad. Barcelona: Gedisa, 2008.

PACHECO, Elza Dias (Org.). Comunicação, educação e arte na cultura infanto-juvenil. São Paulo: Loyola, 1991.

POSTMAN, Neil. O desaparecimento da infância. Rio de Janeiro: Graphia, 1999.

SOUTO, Kely Cristina Nogueira et al (Org.). A infância na mídia. Belo Horizonte: Autêntica, 2009. 
STRASBURGER, Victor C. Os adolescentes e a mídia: impacto psicológico. Porto Alegre: Artmed, 1999.

\subsubsection{Fundamentos da educomunicação e ecossistemas} comunicacionais

Objetivos:

Apresentar as linhas de atuação da educomunicação e estudar a formação de ecossistemas comunicacionais em escolas de Educação Básica.

Programa:

Mediação tecnológica na educação. Educação para a comunicação. Gestão comunicativa. As contribuições de Célestin Freinet, Edgard Roquette-Pinto, Mario Kaplún, Daniel Prieto Castillo, Paulo Freire. Formação cidadã. Processos de promoção de espaços de diálogo horizontais na escola e na comunidade. Práticas educomunicativas. Ecossistemas comunicacionais. Redes de experiências e estudos de caso.

Bibliografia:

BELLONI, Maria Luiza. 0 que é mídia-educação. Campinas: Autores Associados, 2001.

BUCKINGHAM, David. Media education: literacy, learning and contemporary culture. Cambridge: Polity, 2003.

FANTIN, Monica. Mídia-educação: conceitos, experiências, diálogos Brasil-Itália. Florianópolis: Cidade Futura, 2006.

KAPLÚN, Mario. Uma pedagogia de la comunicación. Madri: Ediciones de la Torre, 1998.

REDE DE EXPERIÊNCIAS EM COMUNICAÇÃO, EDUCAÇÃO E PARTICIPAÇÃO. Educomunicar: comunicação, educação e participação para uma educação pública de qualidade. São Paulo: Rede CEP, s/d. 
SIERRA, Francisco. Introducción a la teoria de la comunicación educativa. Madri: Sevilla Editorial, 2000.

SANCHO, Juana María; HERNÁNDEZ, Fernando (Org.). Tecnologias para transformar a educação. Porto Alegre: Artmed, 2006. SOARES, Ismar de Oliveira (Org.). Cadernos de educomunicação 1: caminhos da educomunicação. São Paulo: Salesiana, 2003. VOLPI, Mário; PALAZZO, Ludmila (Org.). Mudando sua escola, mudando sua comunidade, melhorando o mundo!:

sistematização da experiência. Brasília: Rede CEP/Unicef, 2010.

\subsubsection{Fundamentos da crítica do audiovisual}

Objetivos:

Apresentar os fundamentos da leitura crítica no campo do audiovisual por meio de estudos de linguagem e de recepção.

Programa:

Elementos de linguagem e procedimentos de análise. Teorias do cinema e da TV. O conceito de autoria na produção audiovisual. Gêneros e formatos da produção audiovisual. 0 documentário, o telejornalismo e o estatuto da imagem em movimento na sociedade contemporânea. Hibridismo de gêneros e formatos. Tendências da produção audiovisual contemporânea. $\mathrm{O}$ crítico como um pesquisador e o professor de educação audiovisual como um crítico.

Bibliografia:

ANDREW, J. Dudley. As principais teorias do cinema: uma introdução. Rio de Janeiro: Jorge Zahar, 1989.

AUMONT, Jacques. As teorias dos cineastas. Campinas: Papirus, 2004.

Moderno?: por que o cinema se tornou a mais singular das artes. Campinas: Papirus, 2008.

BALOGH, Anna Maria. 0 discurso ficcional na TV. São Paulo: Edusp, 2002. 
BAZIN, André. 0 cinema: ensaios. São Paulo: Brasiliense, 1991.

BERNARDET, Jean-Claude. 0 vôo dos anjos: Bressane Sganzerla: estudo sobre a criação cinematográfica. São Paulo: Brasiliense, 1991.

. O autor no cinema. São Paulo: Brasiliense, 1994.

BOURDIEU, Pierre. Sobre a televisão. Rio de Janeiro: Jorge Zahar, 1997.

COMOLLI, Jean-Louis. Ver e poder: a inocência perdida: cinema, televisão, ficção, documentário. Belo Horizonte: UFMG, 2008.

FERRÉS, Joan. Televisão subliminar: socializando através de comunicações despercebidas. Porto Alegre: Artes Médicas, 1998.

GIACOMANTONIO, Marcello. Os meios audiovisuais. Lisboa: Edições 70, 1986.

JOST, François. Seis lições sobre televisão. Porto Alegre: Sulina, 2004.

JULLIER, Laurent; MARIE, Michel. Lendo as imagens do cinema. São Paulo: Senac-SP, 2009.

MACHADO, Arlindo. A televisão levada a sério. São Paulo: SenacSP, 2001.

MAGALHÃES, Cláudio Márcio. Os programas infantis da TV: teoria e prática para entender a televisão feita para crianças. Belo Horizonte: Autêntica, 2007.

MARTIN, Adrian. ¿Qué es el cine moderno? .Santiago: Uqbar, 2008. MARTÍN-BARBERO, J.; REY, Germán. Os exercícios do ver: hegemonia audiovisual e ficção televisiva. São Paulo: Senac-SP, 2001.

NICHOLS, Bill. Introdução ao documentário. Campinas: Papirus, 2005.

NOGUEIRA, Lisandro. 0 autor na televisão. Goiânia: UFG; São Paulo: Edusp, 2002.

PEREIRA, Sara. A minha TV é um mundo: programação para crianças na era do eclã global. Porto: Campo das Letras, 2007.

POPPER, Karl; CONDRY, John. Televisão: um perigo para a democracia. Lisboa: Gradiva, 1995.

STAM, Robert. Introdução à teoria do cinema. Campinas: Papirus, 2003.

TURNER, Graeme. Cinema como prática social. São Paulo: Summus, 1997.

WHARTON, David; GRANT, Jeremy. Teaching auteur study. Londres: British Film Institute, 2005.

WOLTON, Dominique. Elogio do grande público: uma teoria crítica da televisão. São Paulo: Ática, 1996.

5.6.5. Laboratório de crítica I, II e III 
Objetivos:

Promover exercícios de leitura crítica do audiovisual, em diferentes formas de expressão (texto escrito, aula ou apresentação, produção multimídia).

Programa:

Módulo I: exercícios de crítica da produção cinematográfica de ficção e de não-ficção, de curta, média e longa-metragem.

Módulo II: exercícios de crítica da produção televisiva de ficção e de não-ficção, em diferentes gêneros e formatos.

Módulo III: exercícios de crítica da produção audiovisual de ficção e não-ficção em gêneros e formatos híbridos, e em mídias digitais.

Bibliografia:

Ver a bibliografia das disciplinas Fundamentos da Crítica do Audiovisual e Produção Audiovisual e Meios Digitais.

\subsubsection{Audiovisual e representação}

Objetivos:

Estudar os mecanismos de representação do audiovisual aplicados à produção audiovisual que se refere à História e a representações sociais.

\section{Programa:}

O audiovisual como documento histórico e como agente da História. Memória individual e memória coletiva. Identidades nacionais, raciais e culturais. Narrativas de nação e imaginários nacionais. 
Representação de minorias raciais e étnicas. Procedimentos de reescrita, interpretação e condensação na produção de ficção e de não-ficção. A produção audiovisual na Educação Básica brasileira e as ações afirmativas.

Bibliografia:

ARNT, Héris; HELAL, Ronaldo (Org.). A sociedade na tela do cinema: imagem e comunicação. Rio de Janeiro: E-papers, 2002.

BURGOYNE, Robert. A nação do filme. Brasília: UnB, 2002.

CAPELATO, Maria Helena; MORETTIN, Eduardo; NAPOLITANO, Marcos; SALIBA, Elias Thomé (Org.). História e cinema. São Paulo: Alameda, 2007.

FERRO, Marc. Cinema e história. São Paulo: Paz e Terra, 2010.

FRANÇA, Andréa. Terras e fronteiras no cinema político contemporâneo. Rio de Janeiro: 7Letras, 2003.

GALENO, Alex et al. Brasil em tela: cinema e poéticas do social. Porto Alegre: Sulina, 2008.

KORNIS, Mônica Almeida. Cinema, televisão e história. Rio de Janeiro: Jorge Zahar, 2008.

MACEDO, José Rivair; MONGELLI, Lênia Márcia (Org.). A Idade Média no cinema. São Paulo: Ateliê Editorial, 2009.

NÓVOA, Jorge; BARROS, José D'Assunção (Org). Cinema-história: teorias e representações sociais no cinema. Rio de Janeiro: Apicuri, 2008.

ROSENSTONE, Robert A. A história nos filmes, os filmes na história. São Paulo: Paz e Terra, 2010.

SOUZA, Edileuza Penha de (org.). Negritude, cinema e educação: caminhos para a implementação da Lei 10.639/2003 - Vol. 1. Belo Horizonte: Mazza, 2006.

- Negritude, cinema e educação: caminhos para a implementação da Lei 10.639/2003 - Vol. 2. Belo Horizonte: Mazza, 2007.

5.6.7. Política e economia do audiovisual

Objetivos: 
Estudar as dimensões políticas e econômicas da produção audiovisual na sociedade contemporânea.

\section{Programa:}

A estruturação da atividade cinematográfica. Produção, distribuição e exibição. $O$ negócio do cinema em escala planetária. A hegemonia da indústria dos EUA e os conglomerados de capital multinacional. O fenômeno da dependência econômica externa no cinema brasileiro. Modelos de financiamento baseados em incentivos fiscais e na atuação direta do Estado. Políticas de formação de público. A estruturação da televisão no Brasil e no mundo. A legislação das telecomunicações. O predomínio de grupos privados e a concentração de capital. A "revolução digital": cinema digital, TV digital e interativa. Políticas de democratização e inclusão social.

Bibliografia:

BERNARDET, Jean-Claude. Cinema brasileiro: propostas para uma história. São Paulo: Companhia das Letras, 2009.

BUCCI, Eugênio (Org.). A TV aos 50: criticando a televisão brasileira no seu cinquentenário. São Paulo: Fundação Perseu Abramo, 2000.

CANCLINI, Néstor García. Consumidores e cidadãos: conflitos multiculturais da globalização. Rio de Janeiro: Editora UFRJ, 1999.

CANNITO, Newton. A televisão na era digital: interatividade, convergência e novos modelos de negócio. São Paulo: Summus, 2010.

DE LUCA, Luiz Gonzaga Assis. A hora do cinema digital: democratização e globalização do audiovisual. São Paulo: Imprensa Oficial, 2009.

EPSTEIN, Edward Jay. The big picture: the new logic of money and power in Hollywood. Nova York: Random House, 2005.

FINLER, Joel W. The Hollywood story. Londres: Mandarin, 1988.

GASPARD, John. Rápido, barato e sob controle. São Paulo: TZ, 2010.

HOINEFF, Nelson. A nova televisão: desmassificação e o impasse das grandes redes. Rio de Janeiro: Relume Dumará, 1996. 
MARSON, Melina Izar. Cinema e políticas de Estado: da Embrafilme à Ancine. São Paulo: Escrituras, 2009.

MATTOS, Sérgio. História da televisão brasileira: uma visão econômica, social e política. Petrópolis: Vozes, 2002.

MELEIRO, Alessandra (Org.). Cinema no mundo: indústria, política e mercado, Vol. 1, Vol. 2, Vol. 3, Vol. 4, Vol. 5. São Paulo: Escrituras, 2007.

. Cinema e economia política. São Paulo: Escrituras, 2009. . Cinema e mercado. São Paulo: Escrituras, 2010

ORTIZ, Renato; BORELLI, Silvia Helena Simões; RAMOS, José Mário Ortiz. Telenovela: história e produção. São Paulo: Brasiliense, 1989.

SCHATZ, Thomas. 0 gênio do sistema: a era dos estúdios em Hollywood. São Paulo: Companhia das Letras, 1991.

SEITER, Ellen. Television and new media audiences. New York: Oxford, 1999.

SILVA, Hadija Chalupe da. 0 filme nas telas: a distribuição do cinema nacional. São Paulo: Ecofalante, 2010.

\subsubsection{Ciberespaço, cibercultura e redes}

Objetivos:

Estudar como se constituiu o ciberespaço na sociedade contemporânea e o processo de formação da cibercultura, com destaque para o impacto das redes sociais.

Programa:

Identidade virtual e comunicação digital. Construção de redes e a cultura da virtualidade real. Subjetividade e modos de enunciação. Tentativas de controle e regulamentação. Principais agentes políticos e econômicos. Processos comunicacionais interativos e novas relações de ensino-aprendizagem. Ecossistemas comunicacionais em perspectiva virtual.

Bibliografia: 
CASTELLS, Manuel. A sociedade em rede: a era da informação: economia, sociedade e cultura: volume 1. São Paulo: Paz e Terra, 1999.

CEBRIÁN, Juan Luis. A rede: como nossas vidas serão transformadas pelos novos meios de comunicação. São Paulo: Summus, 1998.

COLL, César; MONEREO, Carles (Org.). Psicologia da educação virtual: aprender e ensinar com as tecnologias da informação e da comunicação. Porto Alegre: Artmed, 2010.

DE LUCA, Luiz Gonzaga Assis. A hora do cinema digital: democratização e globalização do audiovisual. São Paulo: Imprensa Oficial, 2009.

FELINTO, Erick; BENTES, Ivana. Avatar: o futuro do cinema e a ecologia das imagens digitais. Porto Alegre: Sulina, 2010.

LEVY, Pierre. Cibercultura. São Paulo: Loyola, 1999.

MACHADO, Arlindo. 0 sujeito na tela: modos de enunciação no cinema e no ciberespaço. São Paulo: Paulus, 2007.

MORAES, Dênis de. Planeta mídia: tendências da comunicação na era global. Campo Grande: Letra Livre, 1998.

NEGROPONTE, Nicholas. A vida digital. São Paulo: Companhia das Letras, 1995.

RAMAL, Andrea Cecilia. Educação na cibercultura: hipertextualidade, leitura, escrita e aprendizagem. Porto Alegre: Artmed, 2002.

VILCHES, Lorenzo. A migração digital. São Paulo: Edições Loyola, 2003.

VIRILIO, Paul. O espaço crítico. Rio de Janeiro: Ed. 34, 1993.

\subsubsection{Produção audiovisual e meios digitais}

Objetivos:

Estudar a circulação da produção audiovisual em meios digitais, bem como a presença dos meios digitais e da cibercultura em produções audiovisuais distribuídas pelo circuito tradicional.

Programa:

0 impacto da tecnologia digital sobre 0 audiovisual contemporâneo: produção, distribuição, exibição. Democratização do 
acesso à produção e pulverização de emissores. Mecanismos de acesso e padrões de consumo do audiovisual em meios digitais. Tendências de reestruturação do mercado audiovisual com base em tecnologias digitais. Narrativas da cibercultura: a incorporação do ciberespaço como argumento e como tema referencial na produção audiovisual contemporânea de ficção.

Bibliografia:

DE LUCA, Luiz Gonzaga Assis. A hora do cinema digital: democratização e globalização do audiovisual. São Paulo: Imprensa Oficial, 2009.

FELINTO, Erick; BENTES, Ivana. Avatar: o futuro do cinema e a ecologia das imagens digitais. Porto Alegre: Sulina, 2010.

GASPARD, John. Rápido, barato e sob controle. São Paulo: TZ, 2010.

LIPOVETSKY, Gilles; SERROY, Jean. A tela global: mídias culturais e cinema na era hipermoderna. Porto Alegre: Sulina, 2009.

MACIEL, Katia (Org.). Transcinemas. Rio de janeiro: Contra Capa, 2009.

NUNES, Pedro. As relações estéticas no cinema eletrônico. João Pessoa: UFPB; Natal: UFRN; Maceió: UFAL.

SILVA, Alexandre Rocha da; ROSSINI, Miriam de Souza (Org.). Do audiovisual às audiovisualidades: convergência e dispersão nas mídias. Porto Alegre: Asterisco, 2009.

VILCHES, Lorenzo. A migração digital. São Paulo: Edições Loyola, 2003.

\subsubsection{Planejamento pedagógico para a educação audiovisual}

Objetivos:

Apresentar as modalidades de educação audiovisual na Educação Básica e estudar parâmetros para o seu planejamento pedagógico.

Programa: 
Modalidades de educação audiovisual: instrumento paradidático em aulas e demais atividades de disciplinas curriculares; disciplina dedicada ao audiovisual, ou, de modo mais restrito, apenas ao cinema e/ou à TV; projeto interdisciplinar ou multidisciplinar, mobilizando a produção audiovisual, no âmbito da leitura crítica e/ou da realização; atividade extracurricular, em forma de disciplina optativa ou projeto de exibição, de leitura crítica e/ou de realização, e de criação de comunidades de espectadores. Ferramentas de planejamento pedagógico aplicadas à educação audiovisual. Estratégias de intervenção na escola e na comunidade. Estudos de caso.

Bibliografia:

BATTUT, Éric; BENSIMHON, Daniel. Lire et comprendre les images à l'école. Paris: Retz, 2003.

CITTERIO, Raymond; LAPEYSSONIE, Bruno; REYNAUD, Guy. Du cinéma à l'école. Paris: Hachette, 1995.

COLL, Mercè; SELVA, Marta; SOLÀ, Anna. El cinema a l'ensenyament: recurs didàctic o matèria curricular?._Barcelona: Claret, 1997.

COSTA, Cristina. Educação, imagem e mídias. São Paulo: Cortez, 2005.

FOWLER, Charles. Strong arts, strong schools: the promising potential and shortsighted disregard of the arts in American schooling. Nova York: Oxford, 1996.

FRANCO, Marília da Silva. "A natureza pedagógica das linguagens audiovisuais". In: COUTO, José Geraldo. Cinema: uma introdução à produção cinematográfica. São Paulo: FDE, 1993.

GARDNER, Howard. As artes e o desenvolvimento humano. Porto Alegre: Artes Médicas, 1997.

HERNÁNDEZ, Fernando. Cultura visual, mudança educativa e projeto de trabalho. Porto Alegre: Artes Médicas, 2000.

NOBLIT, George W.; CORBETT, H. Dickson; WILSON, Bruce L.; MCKINNEY, Monica B. Creating and sustaining arts-based school reform: the A+ schools program. Nova York: Routledge, 2009.

TARDY, Michel. 0 professor e as imagens. São Paulo: Cultrix/Edusp, 1976. 


\subsubsection{Programação e mediação do audiovisual na escola}

Objetivos:

Estudar conceitos e práticas de mediação de atividades escolares realizadas com o uso do audiovisual.

Programa:

Programação audiovisual na Educação Básica: conexões com disciplinas, com atividades interdisciplinares e multidisciplinares. Formação e utilização de acervos. Planejamento de infra-estrutura técnica e utilização de equipamentos. Mediação em aulas e debates. Curadoria de eventos. Mobilização de redes sociais. Supervisão de produção. Estudos de caso.

Bibliografia:

AZZI, Riolando. Cinema e educação: orientação pedagógica e cultural de vídeos. São Paulo: Paulinas, 1996.

BOLOGNINI, Carmen Zink (org.). Discurso e ensino: cinema na escola. Campinas: Mercado de Letras, 2007.

CARVALHO, Renata Innecco Bittencourt de. Universidade midiatizada: o uso da televisão e do cinema na educação superior. Brasília: Senac-DF, 2007.

COMMAGNAC, Francis; BARILLY, Bertrand. Le caméscope au quotidien: fiches pratiques pour une pédagogie de la vidéo à l'école primaire. Charentes: CRDP, 2003.

FOZZA, Jean-Claude; GARAT, Anne-Marie; PARFAIT, Françoise. Petite fabrique de l'image. Paris: Magnard, 2003.

FRESQUET, Adriana (Org.). Imagens do desaprender: uma experiência de aprender com o cinema. Rio de Janeiro: Booklink: CINEAD-LISE-FE/UFRJ, 2007.

Novas imagens do desaprender: uma experiência de aprender cinema entre a cinemateca e a escola. Rio de Janeiro: Booklink: CINEAD-LISE-FE/UFRJ, 2008. 
- Aprender com experiências do cinema: desaprender com imagens da educação. Rio de Janeiro: Booklink: CINEAD-LISEFE/UFRJ, 2009.

GIACOMANTONIO, Marcello. O ensino através dos audiovisuais. São Paulo: Summus/Edusp, 1976.

GONZÁLEZ BLASCO, Pablo. Educação da afetividade através do cinema. Curitiba: IEF, 2006.

HUET, Anne. On tourne!: écrire avec le cinéma. Paris: Gallimard, 2005.

LAURITO, Ilka Brunilde. Cinema e infância: plano de estudos e orientação bibliográfica. São Paulo: Fundação Cinemateca Brasileira, 1962.

LITWIN, Edith (Org.). Tecnologías educativas en tiempos de internet. Buenos Aires: Amorrortu, 2005.

MARCONDES, Beatriz; MENEZES, Gilda; TOSHIMITSU, Thaís. Como usar outras linguagens na sala de aula. São Paulo: Contexto, 2002.

MAYNARD, Richard A. The celluloid curriculum: how to use movies in the classroom. Rochelle Park (New Jersey): Hayden, 1971.

MILLER, Hannah Elsas. Films in the classroom: a practical guide. Metuchen (New Jersey): Scarecrow, 1979.

MODRO, Nielson Ribeiro. Cineducação: usando o cinema na sala de aula. Joinville: Casamarca, 2005.

NAPOLITANO, Marcos. Como usar a televisão na sala de aula. são Paulo: Contexto, 1999.

Contexto, 2003.

Como usar o cinema na sala de aula. São Paulo:

PERKINS, David N. The intelligent eye: learning to think by looking at art. Los Angeles: Getty, 2004.

PINTO, Manuel; SANTOS, António. O cinema e a escola. Lisboa: Público, 1996.

SORGON, Silvia Regina. Curtindo um filme adoidado: uma reflexão sobre o uso do cinema comercial na escola. Dissertação de mestrado. São Paulo: Universidade Anhembi Morumbi, 1999.

TARDY, Michel. 0 professor e as imagens. São Paulo: Cultrix/Edusp, 1976.

TEASLEY, Alan B.; WILDER, Ann. Reel conversations: reading films with young adults. Portsmouth: Boynton/Cook, 1997.

TEIXEIRA, Inês Assunção de Castro e LOPES, José de Sousa Miguel (Org.). A escola vai ao cinema. Belo Horizonte: Autêntica, 2003. THIEL, Grace Cristiane; THIEL, Janice Cristine. Movie takes: a magia do cinema na sala de aula. Curitiba: Aymará, 2009.

TORRE, Saturnino de la (Org.). Cine formativo: una estrategia innovadora para los docentes. Barcelona: Octaedro, 1997. 
(Org.). Cine para la vida: formación y cambio en el cine. Barcelona: Octaedro, 1998.

; PUJOL, María Antonia; RAJADELL, Núria (Org.). El cine, un

entorno educativo: diez años de experiências a través del cine. Madri: Narcea, 2005.

TURNER, Graeme. Cinema como prática social. São Paulo: Summus, 1997.

VIDÉADOC - CENTRE NATIONAL DE DOCUMENTATION PÉDAGOGIQUE. Images, cinéma, éducation. Paris: Vidéadoc, 2001.

\subsubsection{Realização audiovisual I, II e III}

Objetivos:

Estudar os elementos necessários à realização audiovisual por crianças e jovens na Educação Básica, enfatizando a dinâmica coletiva de trabalho, bem como elementos relacionados a processos de sociabilização, de comunicação interpessoal, de protagonismo, de empreendedorismo, de formação cidadã e de familiaridade com a tecnologia.

\section{Programa:}

Módulo I: tema, argumento e roteiro, com ênfase no formato curta-metragem e na dramaturgia das micronarrativas e dos relatos autobiográficos, no domínio da ficção, e dos modos clássicos do documentário, no domínio da não-ficção.

Módulo II: pré-produção (story-board, roteiro técnico, direção e assistência de produção) e produção (operação de câmera e áudio, iluminação, recursos materiais e humanos, direção de atores, captação de depoimentos, realização de entrevistas, cessão de direito do uso de imagem). 
Módulo III: pós-produção (edição, direitos autorais) e exibição (campanha para lançamento, promoção de debates, apreciação externa e autoavaliação do resultado).

Bibliografia:

BARILLY, Bertrand. Le caméscope au quotidien: fiches pratiques pour une pédagogie de la vidéo à l'école primaire. Charente: CRDP de Poitou-Charentes, 2003.

BAYNAUD, Fabrice e outros. La vidéo avec les élèves: lire, écrire, produire des images et des sons. Créteil: CRDP e l'Académie de Créteil, 2003.

COBO, Alejandro. ¿Es fácil hacer cine en la escuela com pocos recursos y muchos resultados?_Buenos Aires: Biblos, 2008.

DANCYGER, Ken. Técnicas de edição para cinema e vídeo: história, teoria e prática. Rio de Janeiro: Elsevier, 2007.

GOODMAN, Steven. Teaching youth media: a critical guide to literacy, video production, and social change. Nova York: Teachers College Press, 2003.

KENNEDY, Keith. Film in teaching. Londres: Batsford, 1972.

MASCELLI, Joseph V. Os cinco Cs da cinematografia: técnicas de filmagem. São Paulo: Summus, 2010.

McKEE, Robert. Story: substância, estrutura, estilo e os princípios da escrita de roteiro. Curitiba: Arte \& Letra, 2006.

MURCH, Walter. Num piscar de olhos: a edição de filmes sob a ótica de um mestre. Rio de Janeiro: Jorge Zahar, 2004.

PUCCINI, Sérgio. Roteiro de documentário: da pré-produção à pósprodução. Campinas: Papirus, 2009.

RABIGER, Michael. Direção de cinema: técnicas e estética. Rio de Janeiro: Elsevier, 2007.

SCOTT, Kevin Conroy. Lições de roteiristas: roteiristas falam sobre seus filmes mais importantes. Rio de Janeiro: Civilização Brasileira, 2008.

TIRARD, Laurent. Grandes diretores de cinema. Rio de Janeiro: Nova Fronteira, 2006.

WOHLGEMUTH, Julio. Vídeo educativo: uma pedagogia audiovisual. Brasília: Senac-DF, 2005.

\subsection{Atividades complementares}


As atividades complementares são distribuídas ao longo do curso, e envolvem um seminário por módulo semestral, pesquisas de campo em escolas e espaços culturais que realizem atividades de educação audiovisual, bem como participação em eventos direta ou indiretamente relacionados a esse campo de estudos, e visitas monitoradas a sets de filmagem e estúdios de gravação e finalização.

\subsection{Monografia ou trabalho de conclusão de curso}

Como parte dos requisitos para a conclusão do curso, os alunos deverão produzir e apresentar, em banca de avaliação, monografia ou trabalho de conclusão de curso em formato audiovisual, desde que devidamente acompanhado de memorial descritivo. As linhas de pesquisa correspondem aos eixos temáticos da grade curricular, e os temas, inscritos no universo da educação audiovisual no Brasil ou no exterior ${ }^{77}$.

\footnotetext{
77 Regulamento específico, em consonância com as políticas administrativas e pedagógicas da instituição que oferecerá o curso, determinará os parâmetros de produção da monografia ou TCC.
} 


\section{Nem apocalíptica, nem integrada}

Oito décadas atrás, em defesa da "saúde moral", da "construção" e da "regeneração" sociais, Joaquim Canuto Mendes de Almeida afirmou que a educação constituía "o máximo problema nacional", e que o cinema era "necessário" à educação. Descontado o positivismo de seu raciocínio, essas palavras de ordem chegam ao século 21 como se fossem expressas por um cidadão de nosso tempo.

É difícil encontrar quem hoje discorde da necessidade estratégica de se encarar o sistema educacional como um dos problemas cruciais do país - ainda que essa visão, manifestada com muita veemência por candidatos aos mais diversos cargos públicos durante campanhas eleitorais, não se traduza necessariamente em ações. Da mesma forma, basta se visitar uma escola para se notar, pela simples presença de equipamentos audiovisuais, que a atenção à expressão por meio de imagens e sons foi incorporada ao cotidiano educacional. Caso ainda não tenha sido em determinados espaços, é razoável supor que as autoridades escolares gostariam que fosse.

Se o audiovisual tem contribuição significativa a dar à Educação Básica, e acreditamos firmemente que tenha, como incontáveis exemplos já o demonstram, então é preciso que reflitamos sobre as competências relacionadas ao seu uso em sintonia com as oportunidades e os desafios do cenário contemporâneo. Este trabalho oferece, na forma de um curso de especialização em educação audiovisual, referenciais para que sejam discutidos conceitos e práticas a partir dos quais debater, no domínio de redes de ensino e de 
estabelecimentos isolados, a gama de conhecimentos desejáveis para a execução de atividades nessa área com crianças e jovens.

A presença dos meios audiovisuais no cotidiano de professores e de alunos não representa necessariamente a compreensão de seus mecanismos de produção de sentido exigida para que se tornem espectadores capazes de realizar a leitura crítica do que consomem. Ao contrário: a superexposição ao audiovisual, sobretudo se restrita a poucos gêneros e formatos, tende a gerar espectadores habituados a padrões de consumo massificado que relegam ao nicho do exótico qualquer obra ligeiramente distante das coordenadas que lhe são familiares.

"Isso não é cinema!": essa frase e suas equivalentes, utilizadas com frequência com o objetivo de desqualificar um filme, correspondem a uma manifestação, em geral involuntária, de reconhecimento dos limites de repertório. Esse não é o cinema que eu conheço, parece dizer o espectador que, nessas situações, tem dificuldade em estabelecer uma ponte em direção à obra; e, sendo esse cinema um representante do desconhecido, é muito natural, como ocorre em diversas manifestações culturais, que o incômodo se transforme em recusa, e a recusa em desqualificação.

Daí a ênfase, no curso de especialização em educação audiovisual configurado neste trabalho, em provocar a imersão do aluno-professor na cultura audiovisual, expandir-lhe o repertório ao promover seu contato com os diferentes gêneros, formatos e propostas estéticas da produção audiovisual contemporânea, incluindo sua presença em meios digitais e sua relação com a cibercultura, e levá-lo ao exercício sistemático da leitura crítica, desenvolvendo a capacidade de estabelecer conexões e de estimular seus alunos - 
diante não só de obras audiovisuais, mas de toda a representação do mundo que nos é oferecida pela produção cultural - a também o fazer.

Não se propõe aqui uma formação inspirada no pragmatismo generalista dos manuais de uso ou das receitas de aplicação do audiovisual, o famigerado "como utilizar" isto ou aquilo na sala de aula. A proposta de qualificação aqui desenhada prefere acreditar que um educador inserido de forma ativa na cultura audiovisual, e portanto familiarizado com suas múltiplas possibilidades de conexão com a Educação Básica, terá instrumentos para planejar e executar as ações que lhe parecerem mais adequadas para atingir determinados objetivos pedagógicos em contextos específicos. Almeida era paternalista e dirigista; preferimos, mais próximos do pensamento de Roberto Rossellini, uma visão que privilegie a construção da autonomia e o espírito libertário.

Essas coordenadas também justificam outra ênfase do curso de especialização em educação audiovisual estruturado neste trabalho: a realização. Ao estimular em professores a capacidade de se expressar por meio de imagens e sons, graças também à imersão no universo da produção audiovisual e a exercícios sistemáticos de criação individual e coletiva, acredita-se que eles terão não só a oportunidade de aperfeiçoar o entendimento crítico da produção audiovisual devido à abertura da "caixa preta" da realização, mas também a de promover, em bases mais seguras, a travessia de seus alunos em direção à familiaridade com esses recursos de linguagem.

Tal ênfase não foi desenhada porque necessariamente se vislumbre mais tarde uma eventual profissionalização de parcela dos estudantes no mercado de trabalho direta ou indiretamente ligado à cultura audiovisual (o que é razoável supor que ocorra, assim como tantos adultos julgam ter encontrado sua vocação, na infância ou 
adolescência, em aulas e atividades da Educação Básica). Crianças e jovens, independentemente das escolhas que farão para se inserir no mundo do trabalho, têm o direito de serem apresentados à linguagem audiovisual e de se expressarem por meio delas - inclusive para desenvolver recursos que Ihes possibilitem refletir, em perspectiva cidadã e com autonomia crítica, sobre o próprio mundo do trabalho e a sociedade de consumo a ele conectada de forma simbiótica.

A configuração socioeconômica da sociedade contemporânea em um país como o Brasil não precisa de ninguém que estimule o consumo da produção audiovisual entre crianças e jovens; onde houver telas, elas já o fazem sozinhas. Mas é justamente a configuração socioeconômica da sociedade brasileira hoje que exige de educadores uma postura crítica em relação a esse consumo - atitude que, ao mesmo tempo, deve contemplar as oportunidades que o audiovisual oferece para enriquecer a percepção de mundo desenvolvida por crianças e jovens. Nem apocalíptica, nem integrada: a postura mais lúcida passa, como sugere Joan Ferrés, por assumir a ambivalência dos meios audiovisuais e suas contradições internas, buscando o equilíbrio entre o "otimismo ingênuo" e o "catastrofismo estéril". O curso de especialização proposto neste trabalho aponta para um mecanismo de qualificação de professores empenhado em disseminar conhecimentos que possam contribuir para essa busca. 
ACOSTA-ORJUELA, Guillermo Maurício. 15 motivos para "ficar de olho" na televisão. Campinas: Alínea, 1999.

ALMEIDA, Candido José Mendes de Almeida. 0 que é vídeo. São Paulo: Brasiliense, 1984.

ALMEIDA, Joaquim Canuto Mendes de. Cinema contra cinema: bases gerais para um esboço de organização do cinema educativo no Brasil. São Paulo: Companhia Editora Nacional, 1931.

AMAR RODRÍGUEZ, Víctor M. Comprender y disfrutar el cine: la gran pantalla como recurso educativo. Huelva: Comunicar, 2003.

ANDREW, J. Dudley. As principais teorias do cinema: uma introdução. Rio de Janeiro: Jorge Zahar, 1989.

ARISTARCO, Guido; ARISTARCO, Teresa. 0 novo mundo das imagens electrónicas. Lisboa: Edições 70, 1990.

ARNT, Héris; HELAL, Ronaldo (Org.). A sociedade na tela do cinema: imagem e comunicação. Rio de Janeiro: E-papers, 2002.

AUMONT, Jacques. As teorias dos cineastas. Campinas: Papirus, 2004.

Moderno?: por que o cinema se tornou a mais singular das artes. Campinas: Papirus, 2008.

AZZI, Riolando. Cinema e educação: orientação pedagógica e cultural de vídeos. São Paulo: Paulinas, 1996.

BABIN, Pierre; KOULOUMDJIAN, Marie France. Os novos modos de compreender: a geração do audiovisual e do computador. São Paulo: Paulinas, 1989.

BACCEGA, Maria Aparecida. Televisão e escola: uma mediação possível?. São Paulo: Senac, 2003. 
BACHER, Silvia. Tatuados por los medios: dilemas de la educación en la era digital. Buenos Aires: Paidós, 2009.

BALOGH, Anna Maria. 0 discurso ficcional na TV. São Paulo: Edusp, 2002.

BARBOSA, Ana Mae. Arte-educação no Brasil. São Paulo: Perspectiva, 2002.

2005.

A imagem no ensino da arte. São Paulo: Perspectiva, (Org.). Ensino de arte: memória e história. São Paulo: Perspectiva, 2008.

BARILLY, Bertrand. Le caméscope au quotidien: fiches pratiques pour une pédagogie de la vidéo à l'école primaire. Charente: CRDP de Poitou-Charentes, 2003.

BATTUT, Éric; BENSIMHON, Daniel. Lire et comprendre les images à l'école. Paris: Retz, 2003.

BAYNAUD, Fabrice e outros. La vidéo avec les élèves: lire, écrire, produire des images et des sons. Créteil: CRDP e l'Académie de Créteil, 2003.

BAZALGETTE, Cary; BUCKINGHAM, David (Org.). In front of the children: screen entertainment and young audiences. Londres: British Film Institute, 1995.

BAZIN, André. 0 cinema: ensaios. São Paulo: Brasiliense, 1991.

BEAL, J. David. Super 8 e outras bitolas em ação. São Paulo: Summus, 1976.

BELLONI, Maria Luiza. 0 que é mídia-educação. Campinas: Autores Associados, 2001.

(Org.). A formação na sociedade do espetáculo. São Paulo: Edições Loyola, 2002.

Campinas: Papirus, 2010. 
BERNARDET, Jean-Claude. 0 vôo dos anjos: Bressane Sganzerla: estudo sobre a criação cinematográfica. São Paulo: Brasiliense, 1991.

. 0 autor no cinema. São Paulo: Brasiliense, 1994.

Cinema brasileiro: propostas para uma história. São Paulo: Companhia das Letras, 2009.

BESKOW, Cristina Alvares. Comunicação, educação e inclusão digital: quem "tá ligado" na escola estadual paulista?. 2008. Dissertação (Mestrado em Ciências da Comunicação) - Escola de Comunicações e Artes, Universidade de São Paulo, São Paulo, 2008.

BLACKABY, Linda; GEORGAKAS, Dan; MARGOLIS, Barbara. In focus: a guide to using films. Nova York: Zoetrope, 1980.

BOLOGNINI, Carmen Zink (Org.). Discurso e ensino: cinema na escola. Campinas: Mercado de Letras, 2007.

BOURDIEU, Pierre. Sobre a televisão. Rio de Janeiro: Jorge Zahar, 1997.

BRIAND, Dominique; PINSON, Gérard. Enseigner I'histoire avec des images: école, collège, lycée. Paris: Hachette, 2008.

BUCCI, Eugênio (Org.). A TV aos 50: criticando a televisão brasileira no seu cinquentenário. São Paulo: Fundação Perseu Abramo, 2000.

BUCKINGHAM, David. Media education: literacy, learning and contemporary culture. Cambridge: Polity, 2003.

BUÑUEL, Luis. Meu último suspiro. Rio de Janeiro: Nova Fronteira, 1982.

BURGOYNE, Robert. A nação do filme. Brasília: UnB, 2002.

CANCLINI, Néstor García. Consumidores e cidadãos: conflitos multiculturais da globalização. Rio de Janeiro: Editora UFRJ, 1999.

CANNITO, Newton. A televisão na era digital: interatividade, convergência e novos modelos de negócio. São Paulo: Summus, 2010.

CAPELATO, Maria Helena; MORETTIN, Eduardo; NAPOLITANO, Marcos; SALIBA, Elias Thomé (Org.). História e cinema. São Paulo: Alameda, 2007. 
CARLSSON, Ulla; FEILITZEN, Cecilia von. A criança e a mídia: imagem, educação, participação. São Paulo: Cortez; Brasília: Unesco, 2002.

CARVALHO, Renata Innecco Bittencourt de. Universidade midiatizada: o uso da televisão e do cinema na educação superior. Brasília: Senac-DF, 2007.

CASTELLS, Manuel. A sociedade em rede: a era da informação: economia, sociedade e cultura: volume 1. São Paulo: Paz e Terra, 1999.

CEBRIÁN, Juan Luis. A rede: como nossas vidas serão transformadas pelos novos meios de comunicação. São Paulo: Summus, 1998.

CIPOLINI, Arlete. Não é fita, é fato: tensões entre instrumento e objeto: um estudo sobre a utilização do cinema na educação. 2008. Dissertação (Mestrado em Educação) - Faculdade de Educação, Universidade de São Paulo, São Paulo, 2008.

CITELLI, Adilson (Org.). Outras linguagens na escola. São Paulo: Cortez, 2001.

CITTERIO, Raymond; LAPEYSSONIE, Bruno; REYNAUD, Guy. Du cinéma à l'école. Paris: Hachette, 1995.

COBO, Alejandro. ¿Es fácil hacer cine en la escuela com pocos recursos y muchos resultados?_Buenos Aires: Biblos, 2008.

COLL, César; MONEREO, Carles (Org.). Psicologia da educação virtual: aprender e ensinar com as tecnologias da informação e da comunicação. Porto Alegre: Artmed, 2010.

COLL, Mercè; SELVA, Marta; SOLÀ, Anna. El cinema a l'ensenyament: recurs didàctic o matèria curricular?. Barcelona: Claret, 1997.

COMMAGNAC, Francis; BARILLY, Bertrand. Le caméscope au quotidien: fiches pratiques pour une pédagogie de la vidéo à l'école primaire. Charentes: CRDP, 2003.

COMOLLI, Jean-Louis. Ver e poder: a inocência perdida: cinema, televisão, ficção, documentário. Belo Horizonte: UFMG, 2008. 
CORREA JR., Fausto Douglas. A Cinemateca Brasileira: das luzes aos anos de chumbo. São Paulo: Unesp, 2010.

COSTA, Cristina. Educação, imagem e mídias. São Paulo: Cortez, 2005.

DANCYGER, Ken. Técnicas de edição para cinema e vídeo: história, teoria e prática. Rio de Janeiro: Elsevier, 2007.

DAVIDSON, Cathy N.; GOLDBERG, David Theo. The future of learning institutions in a digital age. Cambridge (EUA): The MIT Press, 2009.

DE LUCA, Luiz Gonzaga Assis. A hora do cinema digital: democratização e globalização do audiovisual. São Paulo: Imprensa Oficial, 2009.

DUARTE, Rosália. Cinema \& educação. Belo Horizonte: Autêntica, 2002.

ECO, Umberto. Apocalípticos e integrados. São Paulo: Perspectiva, 1993.

EPSTEIN, Edward Jay. The big picture: the new logic of money and power in Hollywood. Nova York: Random House, 2005.

FANTIN, Monica. Mídia-educação: conceitos, experiências, diálogos Brasil-Itália. Florianópolis: Cidade Futura, 2006.

FARIA, Maria Alice. Como usar o jornal na sala de aula. São Paulo: Contexto, 1996.

FEILITZEN, Cecilia Von; BUCHT, Catharina. Perspectivas sobre a criança e a mídia. Brasília: Unesco, SEDH/Ministério da Justiça. 2002.

FELINTO, Erick; BENTES, Ivana. Avatar: o futuro do cinema e a ecologia das imagens digitais. Porto Alegre: Sulina, 2010.

FERRÉS, Joan. Televisão e educação. Porto Alegre: Artes Médicas, 1996.

Televisão subliminar: socializando através de comunicações despercebidas. Porto Alegre: Artes Médicas, 1998. 

. Vídeo e educação. Porto Alegre: Artes Médicas, 1996.

FERRO, Marc. Cinema e história. São Paulo: Paz e Terra, 2010.

FINLER, Joel W. The Hollywood story. Londres: Mandarin, 1988.

FISCHER, Rosa Maria Bueno. Televisão \& educação: fruir e pensar a TV. Belo Horizonte: Autêntica, 2001.

FOWLER, Charles. Strong arts, strong schools: the promising potential and shortsighted disregard of the arts in American schooling. Nova York: Oxford, 1996.

FOZZA, Jean-Claude; GARAT, Anne-Marie; PARFAIT, Françoise. Petite fabrique de l'image. Paris: Magnard, 2003.

FRANÇA, Andréa. Terras e fronteiras no cinema político contemporâneo. Rio de Janeiro: 7Letras, 2003.

FRANCO, Marília da Silva. A natureza pedagógica das linguagens audiovisuais. In: COUTO, José Geraldo. Cinema: uma introdução à produção cinematográfica. São Paulo: FDE, 1993.

FRESQUET, Adriana (Org.). Imagens do desaprender: uma experiência de aprender com o cinema. Rio de Janeiro: Booklink: CINEAD-LISE-FE/UFRJ, 2007.

- Novas imagens do desaprender: uma experiência de aprender cinema entre a cinemateca e a escola. Rio de Janeiro: Booklink: CINEAD-LISE-FE/UFRJ, 2008.

Aprender com experiências do cinema: desaprender com imagens da educação. Rio de Janeiro: Booklink: CINEAD-LISEFE/UFRJ, 2009.

GALENO, Alex et al. Brasil em tela: cinema e poéticas do social. Porto Alegre: Sulina, 2008.

GARDNER, Howard. As artes e o desenvolvimento humano. Porto Alegre: Artes Médicas, 1997.

GASPARD, John. Rápido, barato e sob controle. São Paulo: TZ, 2010. 
GIACOMANTONIO, Marcello. O ensino através dos audiovisuais. São Paulo: Summus/Edusp, 1976.

. Os meios audiovisuais. Lisboa: Edições 70, 1986.

GONZÁLEZ BLASCO, Pablo. Educação da afetividade através do cinema. Curitiba: IEF, 2006.

GOODMAN, Steven. Teaching youth media: a critical guide to literacy, video production, and social change. Nova York: Teachers College Press, 2003.

GUARNER, José Luis. Roberto Rossellini. Madri: Fundamentos, 1972.

GUIMARÃES, Glaucia. TV e escola: discursos em confronto. São Paulo: Cortez, 2000.

HERNÁNDEZ, Fernando. Cultura visual, mudança educativa e projeto de trabalho. Porto Alegre: Artes Médicas, 2000.

HOINEFF, Nelson. A nova televisão: desmassificação e o impasse das grandes redes. Rio de Janeiro: Relume Dumará, 1996.

HUET, Anne. On tourne!: écrire avec le cinéma. Paris: Gallimard, 2005.

JONES, Gerard. Brincando de matar monstros: por que as crianças precisam de fantasia, videogames e violência de faz-de-conta. São Paulo: Conrad, 2004.

JOST, François. Seis lições sobre televisão. Porto Alegre: Sulina, 2004.

JULLIER, Laurent; MARIE, Michel. Lendo as imagens do cinema. São Paulo: Senac-SP, 2009.

KAPLÚN, Mario. Una pedagogia de la comunicación. Madri: Ediciones de la Torre, 1998.

KATZ, John Stuart. Perspectives on the study of film. Boston: Little, Brown and Company, 1971.

KENNEDY, Keith. Film in teaching. Londres: Batsford, 1972. 
KORNIS, Mônica Almeida. Cinema, televisão e história. Rio de Janeiro: Jorge Zahar, 2008.

LARROSA, Jorge; CASTRO, Inês Assunção; SOUSA, José de (Org.). Miradas cinematográficas sobre la infancia: niños atravesando el paisaje. Buenos Aires: Miño y Dávila, 2007.

LAURITO, Ilka Brunilde. Cinema e infância: plano de estudos e orientação bibliográfica. São Paulo: Fundação Cinemateca Brasileira, 1962.

LEITE, Lígia Silva (Coord.). Tecnologia educacional: descubra suas possibilidades na sala de aula. Petrópolis: Vozes, 2003.

LEVY, Pierre. Cibercultura. São Paulo: Loyola, 1999.

LIPOVETSKY, Gilles; SERROY, Jean. A tela global: mídias culturais e cinema na era hipermoderna. Porto Alegre: Sulina, 2009.

LITWIN, Edith (Org.). Tecnologías educativas en tiempos de internet. Buenos Aires: Amorrortu, 2005.

MACEDO, José Rivair; MONGELLI, Lênia Márcia (Org.). A Idade Média no cinema. São Paulo: Ateliê Editorial, 2009.

MACHADO, Arlindo. A arte do vídeo. São Paulo: Brasiliense, 1988.

. O sujeito na tela: modos de enunciação no cinema e no ciberespaço. São Paulo: Paulus, 2007.

A televisão levada a sério. São Paulo: Senac-SP, 2001.

MACIEL, Katia (Org.). Transcinemas. Rio de janeiro: Contra Capa, 2009.

MAGALHÃES, Cláudio Márcio. Os programas infantis da TV: teoria e prática para entender a televisão feita para crianças. Belo Horizonte: Autêntica, 2007.

MARCÍlIO, Maria Luiza. História da escola em São Paulo e no Brasil. São Paulo: Imprensa Oficial, 2005.

MARCONDES, Beatriz; MENEZES, Gilda; TOSHIMITSU, Thaís. Como usar outras linguagens na sala de aula. São Paulo: Contexto, 2002. 
MARSON, Melina Izar. Cinema e políticas de Estado: da Embrafilme à Ancine. São Paulo: Escrituras, 2009.

MARTIN, Adrian. Qué es el cine moderno? . Santiago: Uqbar, 2008.

MARTÍN-BARBERO, J.; REY, Germán. Os exercícios do ver: hegemonia audiovisual e ficção televisiva. São Paulo: Senac-SP, 2001.

MASCELLI, Joseph V. Os cinco Cs da cinematografia: técnicas de filmagem. São Paulo: Summus, 2010.

MATTOS, Sérgio. História da televisão brasileira: uma visão econômica, social e política. Petrópolis: Vozes, 2002.

MAYNARD, Richard A. The celluloid curriculum: how to use movies in the classroom. Rochelle Park (New Jersey): Hayden, 1971.

MAZZARELLA, Sharon R. (Org.). Os jovens e a mídia: 20 questões. Porto Alegre: Artmed, 2009.

McCOURT, Frank. Ei, professor. Rio de Janeiro: Intrínseca, 2006.

McKEE, Robert. Story: substância, estrutura, estilo e os princípios da escrita de roteiro. Curitiba: Arte \& Letra, 2006.

MCLUHAN, Marshall. 0 meio são as massa-gens. Rio de Janeiro: Record, 1969.

MELEIRO, Alessandra (Org.). Cinema no mundo: indústria, política e mercado, Vol. 1. São Paulo: Escrituras, 2007.

. Cinema e economia política. São Paulo: Escrituras, 2009.

. Cinema e mercado. São Paulo: Escrituras, 2010.

MENEZES, Gilda; MARCONDES, Beatriz; TOSHIMITSU, Thaís. Como usar outras linguagens na sala de aula. São Paulo: Contexto, 2002.

MILLER, Hannah Elsas. Films in the classroom: a practical guide. Metuchen (New Jersey): Scarecrow, 1979.

MIRANDA, Carlos Eduardo Albuquerque; RIGOTTI, Gabriela Fiorin (Org.). Imagens e educação: estudos. São Paulo: Fuiza, 2006. 
MODRO, Nielson Ribeiro. Cineducação: usando o cinema na sala de aula. Joinville: Casamarca, 2005.

MONGIN, Olivier. A violência das imagens: ou como eliminá-la? Lisboa: Bizâncio, 1998.

MORAES, Dênis de. Planeta mídia: tendências da comunicação na era global. Campo Grande: Letra Livre, 1998.

MORAIS, Regis de. TV e educação: entre o caos e o horizonte. Campinas: Alínea, 2009.

MORDUCHOWICZ, Roxana (Org.). Los jóvenes y las pantallas: nuevas formas de sociabilidad. Barcelona: Gedisa, 2008.

MORETTIN, Eduardo Victorio. Os limites de um projeto de monumentalização cinematográfica: uma análise do filme "Descobrimento do Brasil" (1937), de Humberto Mauro. 2001. Tese (Doutorado em Ciências da Comunicação) - Escola de Comunicações e Artes, Universidade de São Paulo, São Paulo, 2001.

MORRONE, Maria Lucia. Cinema e educação (1920-1945): a participação da "imagem em movimento" nas diretrizes da Educação Nacional e nas práticas pedagógicas escolares. 1997. Dissertação (Mestrado em Educação) - Faculdade de Educação, Universidade de São Paulo, São Paulo, 1997.

MURCH, Walter. Num piscar de olhos: a edição de filmes sob a ótica de um mestre. Rio de Janeiro: Jorge Zahar, 2004.

NAPOLITANO, Marcos. Como usar a televisão na sala de aula. são Paulo: Contexto, 1999.

Contexto, 2003.

NEGROPONTE, Nicholas. A vida digital. São Paulo: Companhia das Letras, 1995.

NETTO, Samuel Pfromm. Telas que ensinam: mídia e aprendizagem: do cinema ao computador. Campinas: Alínea, 1998.

NICHOLS, Bill. Introdução ao documentário. Campinas: Papirus, 2005. 
NOBLIT, George W.; CORBETT, H. Dickson; WILSON, Bruce L.; McKINNEY, Monica B. Creating and sustaining arts-based school reform: the A+ schools program. Nova York: Routledge, 2009.

NOGUEIRA, Lisandro. 0 autor na televisão. Goiânia: UFG; São Paulo: Edusp, 2002.

NÓVOA, Jorge; BARROS, José D'Assunção (Org). Cinema-história: teorias e representações sociais no cinema. Rio de Janeiro: Apicuri, 2008.

NÓVOA, Jorge; FRESSATO, Soleni Biscouto; FEIGELSON, Kristian (Org.). Cinematógrafo: um olhar sobre a história. Salvador: EDUFBA; São Paulo: Unesp, 2009.

NUNES, Pedro. As relações estéticas no cinema eletrônico. João Pessoa: UFPB; Natal: UFRN; Maceió: UFAL.

OLIVEIRA, Tania Amaral. Uso da TV e do vídeo no espaço escolar: uma experiência em educomunicação. 2003. Dissertação (Mestrado em Ciências da Comunicação) - Escola de Comunicações e Artes, Universidade de São Paulo, São Paulo, 2003.

ORTIZ, Renato; BORELLI, Silvia Helena Simões; RAMOS, José Mário Ortiz. Telenovela: história e produção. São Paulo: Brasiliense, 1989.

PACHECO, Elza Dias (Org.). Comunicação, educação e arte na cultura infanto-juvenil. São Paulo: Loyola, 1991.

PEREIRA, Katia Helena. Como usar artes visuais na sala de aula. São Paulo: Contexto, 2007.

PEREIRA, Sara. A minha TV é um mundo: programação para crianças na era do eclã global. Porto: Campo das Letras, 2007.

PEREIRA JUNIOR, Luiz Costa. A vida com a TV: o poder da televisão no cotidiano. São Paulo: Senac-SP, 2002.

PERKINS, David N. The intelligent eye: learning to think by looking at art. Los Angeles: Getty, 2004.

PETERS, J. M. L. Teaching about the film: a Unesco study. Nova York: Columbia University Press, 1961. 
PINTO, Manuel; SANTOS, António. O cinema e a escola. Lisboa: Público, 1996.

POPPER, Karl; CONDRY, John. Televisão: um perigo para a democracia. Lisboa: Gradiva, 1995.

POSTMAN, Neil. O desaparecimento da infância. Rio de Janeiro: Graphia, 1999.

PRIETO CASTILLO, Daniel. La televisión en la escuela -- Vol. 1 e 2. Buenos Aires: Lumen Humanitas, 1999.

PRIEUR, Jerôme. 0 espectador noturno: os escritores e o cinema. Rio de Janeiro: Nova Fronteira, 1993.

PUCCINI, Sérgio. Roteiro de documentário: da pré-produção à pósprodução. Campinas: Papirus, 2009.

RABIGER, Michael. Direção de cinema: técnicas e estética. Rio de Janeiro: Elsevier, 2007.

RAMAL, Andrea Cecilia. Educação na cibercultura: hipertextualidade, leitura, escrita e aprendizagem. Porto Alegre: Artmed, 2002.

RAMOS, Fernão; MIRANDA, Luiz Felipe (Org.). Enciclopédia do cinema brasileiro. São Paulo: Senac-SP, 2000.

Mas afinal... o que é mesmo documentário?. São Paulo: Senac-SP, 2008.

REDE DE EXPERIÊNCIAS EM COMUNICAÇÃO, EDUCAÇÃO E PARTICIPAÇÃO. Educomunicar: comunicação, educação e participação para uma educação pública de qualidade. São Paulo: Rede CEP, s/d.

RITTAUD-HUTINET, Jacques. Os irmãos Lumière: a invenção do cinema. São Paulo: Scritta, 1995.

ROMAGUERA I RAMIÓ, Joaquim e ALSINA THEVENET, Homero (Org.). Textos y manifestos del cine. Madrid: Cátedra, 1989.

ROSENSTONE, Robert A. A história nos filmes, os filmes na história. São Paulo: Paz e Terra, 2010. 
ROSSELLINI, Roberto. Un espíritu libre no debe aprender como esclavo: escritos sobre cine y educación. Barcelona: Paidós, 2001. . Le cinéma révélé. Paris: Flammarion, 2008.

SALIBA, Maria Eneida Fachini. Cinema contra cinema: o cinema educativo de Canuto Mendes (1922-1931). São Paulo: Annablume/Fapesp, 2003.

SANCHO, Juana María; HERNÁNDEZ, Fernando (Org.). Tecnologias para transformar a educação. Porto Alegre: Artmed, 2006.

SCHATZ, Thomas. O gênio do sistema: a era dos estúdios em Hollywood. São Paulo: Companhia das Letras, 1991.

SCHVARZMAN, Sheila. Humberto Mauro e as imagens do Brasil. São Paulo: Editora Unesp, 2004.

SCOTT, Kevin Conroy. Lições de roteiristas: roteiristas falam sobre seus filmes mais importantes. Rio de Janeiro: Civilização Brasileira, 2008.

SEITER, Ellen. Television and new media audiences. New York: Oxford, 1999.

SERVIÇO SOCIAL DO COMÉRCIO. A escola vai ao cinema. Brasília: Sesc, 2007.

SETTON, Maria da Graça Jacintho (Org.). A cultura da mídia na escola: ensaios sobre cinema e educação. São Paulo: Annablume: USP, 2004.

SIERRA, Francisco. Introducción a la teoria de la comunicación educativa. Madri: Sevilla Editorial, 2000.

SILVA, Alexandre Rocha da; ROSSINI, Miriam de Souza (Org.). Do audiovisual às audiovisualidades: convergência e dispersão nas mídias. Porto Alegre: Asterisco, 2009.

SILVA, Ana Cristina Venancio da. Uma videoteca para a educação: o projeto Ceduc-vídeo, a Videoteca Pedagógica e as publicações sobre cinema e educação produzidas na Fundação para o Desenvolvimento da Educação - FDE entre 1988 e 1997. 2009. Dissertação (Mestrado em Educação) - Faculdade de Educação, Universidade de São Paulo, São Paulo, 2009. 
SILVA, Hadija Chalupe da. 0 filme nas telas: a distribuição do cinema nacional. São Paulo: Ecofalante, 2010.

SOARES, Ismar de Oliveira (Org.). Cadernos de educomunicação 1: caminhos da educomunicação. São Paulo: Salesiana, 2003.

SOARES, Mariza de Carvalho; FERREIRA, Jorge (Org.). A história vai ao cinema: vinte filmes brasileiros comentados por historiadores. Rio de Janeiro: Record, 2001.

SORGON, Silvia Regina. Curtindo um filme adoidado: uma reflexão sobre o uso do cinema comercial na escola. 1999. Dissertação (Mestrado em Comunicação) - Universidade Anhembi Morumbi, São Paulo, 1999.

SOUTO, Kely Cristina Nogueira et al (Org.). A infância na mídia. Belo Horizonte: Autêntica, 2009.

SOUZA, Edileuza Penha de (Org.). Negritude, cinema e educação: caminhos para a implementação da Lei 10.639/2003 - Vol. 1. Belo Horizonte: Mazza, 2006.

- Negritude, cinema e educação: caminhos para a implementação da Lei 10.639/2003 - Vol. 2. Belo Horizonte: Mazza, 2007.

STAM, Robert. Introdução à teoria do cinema. Campinas: Papirus, 2003.

STRASBURGER, Victor C. Os adolescentes e a mídia: impacto psicológico. Porto Alegre: Artmed, 1999.

TARDY, Michel. 0 professor e as imagens. São Paulo: Cultrix/Edusp, 1976.

TAVARES, Clara Ferrão. A escola e a televisão: olhares cruzados. Lisboa: Plátano, 2004.

TEASLEY, Alan B.; WILDER, Ann. Reel conversations: reading films with young adults. Portsmouth: Boynton/Cook, 1997.

TEIXEIRA, Inês Assunção de Castro e LOPES, José de Sousa Miguel (Org.). A escola vai ao cinema. Belo Horizonte: Autêntica, 2003. 
THIEL, Grace Cristiane; THIEL, Janice Cristine. Movie takes: a magia do cinema na sala de aula. Curitiba: Aymará, 2009.

TIRARD, Laurent. Grandes diretores de cinema. Rio de Janeiro: Nova Fronteira, 2006.

TORRE, Saturnino de la (Org.). Cine formativo: una estrategia innovadora para los docentes. Barcelona: Octaedro, 1997.

(Org.). Cine para la vida: formación y cambio en el cine. Barcelona: Octaedro, 1998.

; PUJOL, María Antonia; RAJADELL, Núria (Org.). El cine, un entorno educativo: diez años de experiências a través del cine. Madri: Narcea, 2005.

TURNER, Graeme. Cinema como prática social. São Paulo: Summus, 1997.

VIDÉADOC - CENTRE NATIONAL DE DOCUMENTATION PÉDAGOGIQUE. Images, cinéma, éducation. Paris: Vidéadoc, 2001.

VILCHES, Lorenzo. A migração digital. São Paulo: Edições Loyola, 2003.

VIRILIO, Paul. O espaço crítico. Rio de Janeiro: Ed. 34, 1993.

VOLPI, Mário; PALAZZO, Ludmila (Org.). Mudando sua escola, mudando sua comunidade, melhorando o mundo!:

sistematização da experiência. Brasília: Rede CEP/Unicef, 2010.

WHARTON, David; GRANT, Jeremy. Teaching auteur study. Londres: British Film Institute, 2005.

WOHLGEMUTH, Julio. Vídeo educativo: uma pedagogia audiovisual. Brasília: Senac-DF, 2005.

WOLTON, Dominique. Elogio do grande público: uma teoria crítica da televisão. São Paulo: Ática, 1996. 


\title{
Rascunho autobiográfico de um
}

\section{espectador}

\begin{abstract}
"Houve anos em que eu ia ao cinema quase todos os dias e, com um pouco de sorte, duas vezes ao dia, e eram os anos (...) de minha adolescência. Anos em que o cinema era o mundo para mim. Outro mundo que não o que me cercava, mas para mim apenas o que eu via na tela possuía as propriedades de um mundo, a plenitude, a necessidade, a coerência, ao passo que fora da tela se amontoavam elementos heterogêneos, como que juntados ao acaso, os materiais de minha vida, que me pareciam desprovidos de toda e qualquer forma.

O cinema como evasão, já se disse tantas vezes, numa fórmula que se pretende condenatória, e certamente a mim o cinema naquela época servia para isso, para satisfazer uma necessidade de estranhamento, de projetar minha atenção num espaço diferente, uma necessidade que acredito corresponder a uma função primária de nossa inserção no mundo, uma etapa indispensável a toda formação."
\end{abstract}

Italo Calvino (1923-1985) 78

\footnotetext{
${ }^{78}$ Parágrafos de abertura do texto memorialístico "Autobiografia de um espectador" (Autobiografia di uno spettatore), escrito como prefácio de Quattro film, de Federico Fellini (Turim: Einaudi, 1974), e publicado no Brasil na coletânea 0 caminho de San Giovanni (São Paulo: Companhia das Letras, 2000).
} 
A julgar pelos meus 11 anos como aluno de Educação Básica, as conexões entre o audiovisual e a escola no Brasil equivaleriam à presença de extraterrestres entre nós: há quem diga que existam, e até mesmo quem tenha publicado livros ou realizado filmes sobre eles, mas não tive pessoalmente a oportunidade de conhecê-los.

Cursei as oito séries do antigo Primeiro Grau - as primeiras quatro em escola particular, mantida por congregação de irmãs franciscanas, e as demais em escola estadual, ambas na Zona Leste de São Paulo, onde morava desde que nasci - de 1972 a 1979. Em seguida, fiz em escola técnica federal, na Zona Norte, os dois primeiros anos do antigo Segundo Grau, que concluí novamente em escola estadual, outra vez na Zona Leste. Desse período, guardo apenas uma recordação ligada ao audiovisual no ambiente escolar: uma aula de Ciências, realizada em laboratório, que incluiu a projeção, provavelmente em $16 \mathrm{~mm}$, de filme didático cujas imagens se perderam na memória, restando apenas a lembrança (duvidosa, porque talvez sugestionada pela minha experiência posterior) de uma narração entrecortada e enfadonha.

Pode-se argumentar que, antes da popularização do videocassete, dos computadores e dos sistemas simplificados de projeção, a tecnologia necessária para a exibição de obras audiovisuais, ainda que relativamente simples, não estava ao alcance de todas as escolas, mesmo na cidade de São Paulo. Mas ao menos uma das escolas onde estudei, aquela onde houve a tal aula de Ciências, tinha projetor, ou algum modo de arrumá-lo. Por que não se recorreu a ele em outras ocasiões no período em que estudei ali?

Além disso, durante os meus 11 anos de Educação Básica, jamais a cultura audiovisual foi tratada em sala de aula ou em dinâmica extracurricular - termo que, salvo engano, ainda não pertencia ao 
cotidiano escolar. Nenhuma atividade relacionada ao cinema e à televisão, nenhuma referência a esses meios inserida no desenvolvimento de um conteúdo qualquer e, obviamente, nenhuma espécie de estímulo a que fôssemos a uma sala de cinema ou assistíssemos a determinado programa na TV.

É bem verdade que a escola onde me alfabetizei me apresentou em excursão (a primeira sem a presença de meus pais, aos seis anos de idade) à Cidade da Criança - que, como eu só viria a descobrir muito mais tarde, foi construída em parte do espaço cenográfico utilizado para a filmagem de externas pela Companhia Cinematográfica Vera Cruz, em São Bernardo do Campo. O passeio me proporcionou conexão involuntária, portanto, com um dos capítulos mais ricos na história do cinema nacional, e foi curiosamente registrado em foto na qual, por falar em cinema, apareço controlando brinquedo inspirado em arma de ficção científica, semelhante a uma metralhadora giratória, mas com a aparência de que poderia fulminar eventuais inimigos - extraterrestres, decerto - com raios letais, em vez de balas.

Sei que essa referência ao universo fantasioso do audiovisual (e também das histórias em quadrinhos) já fazia sentido aos meus seis anos de idade porque seriados como Perdidos no espaço e Terra de gigantes, produzidos nos anos 1960, eram então reprisados no Brasil e já me seduziam ${ }^{79}$. Evidentemente, não era o único de meus colegas

\footnotetext{
${ }^{79} \mathrm{O}$ produtor norte-americano Irwin Allen (1916-1991) criou os seriados Perdidos no espaço (Lost in space) e Terra de gigantes (Land of giants), bem como Viagem ao fundo do mar (Voyage to the bottom of the sea, baseado em longa-metragem homônimo dirigido pelo próprio Allen) e Túnel do tempo (The time tunnel). Somados, os quatro tiveram cerca de 260 episódios de 52 minutos cada (ocupando uma hora de programação), originalmente filmados (em película, como era costume nas primeiras décadas da TV) de 1964 a 1970. Ao chegar à adolescência, graças a inúmeras reprises, estimei ter visto todos os episódios dos quatro seriados produzidos por Allen. Eles correspondem, junto com os 79 episódios de Jornada nas estrelas (Star trek), produzidos por Gene Roddenberry (1921-1991) de 1966 a
} 
nessa situação. Nascido em 1965, cresci em lar onde já havia aparelhos de televisão, inicialmente apenas na sala de estar e depois também nos quartos, algo que sempre me pareceu comum a todos os de minha geração e classe social.

Meus pais não tinham preconceito quanto ao que vinha dali, exceto no que se referia a material que consideravam ainda inadequado à minha idade. A censura doméstica era frouxa, no entanto, porque passavam por ela os faroestes e policiais, em formato de longametragem e de seriados, que meu pai adorava - e, por mais que cultue hoje esses primeiros arroubos de sessão adulta, não me parece que Rastros de ódio e Missão: impossível fossem recomendados para uma criança de quatro ou cinco anos ${ }^{80}$.

Se reconstituo essa vivência como espectador, que incluía ainda programas chamados de "educacionais" como Vila Sésamo ${ }^{81}$, é com o objetivo de sublinhar a distância entre o repertório audiovisual dos alunos de então e o mundo da educação formal. Cinema e televisão ocupavam em nosso cotidiano um lugar privilegiado, mas referências à sua existência não pareciam caber na escola. Logo, por ali não passava nem mesmo um frágil esboço de política de formação de público para o cinema (que pudesse, inclusive, contrabalançar a presença agressiva da

\footnotetext{
1969, à pedra fundamental, de caráter afetivo insubstituível, do meu repertório audiovisual.

80 Rastros de ódio (The searchers, 1956), de John Ford (1894-1973), é um dos primeiros longas-metragens que lembro ter visto, ainda criança, na TV; agradeço ao professor Ângelo Piovesan, em exercício durante disciplina de pós-graduação na ECAUSP, a oportunidade de recuperar um pouco do sentido afetivo que atribuo a esse filme. O seriado Missão: impossivel (Mission: impossible, 1966-1973), criado por Bruce Geller (1930-1978), foi o primeiro a me despertar claramente a excitação e o mistério da descoberta de elementos do mundo adulto. Diante do que via na tela, me sentia como a menina Ana (Ana Torrent) diante do microcosmo social que a cercava em Cria Cuervos (idem, 1976), do espanhol Carlos Saura.

${ }^{81}$ Criada por Joan Ganz Cooney (1929- ), Vila Sésamo (Sesame Street) estreou nos EUA em 1969 e chegou ao Brasil em 1972, em adaptação produzida por parceria entre a Rede Globo e a TV Cultura de São Paulo.
} 
TV e contrastá-la com outra modalidade de experiência audiovisual), muito menos de formação de jovens espectadores alfabetizados como hoje dizemos, de modo corriqueiro - na linguagem audiovisual e capazes minimamente de reconhecer as coordenadas básicas por meio das quais se processa a expressão de ideias por meio de imagens e sons.

Vivíamos sob regime militar, o que explica em parte a falta de empenho das autoridades escolares - e dos que respondiam a elas em fomentar espírito crítico frente, por exemplo, às práticas do telejornalismo sob censura governamental. Por outro lado, nem mesmo um longa-metragem oficialesco como Independência ou morte (1972), de Carlos Coimbra, lançado na esteira das comemorações do Sesquicentenário da Independência, foi capaz de furar o cerco de desprezo ao audiovisual. Naquele Sete de Setembro, marchei com o uniforme de estudante pelas ruas do bairro, mas a noção de dever cívico não passava por assistir a Tarcísio Meira, então o principal galã de telenovelas, no papel de D. Pedro II, e à sua mulher e habitual parceira na tela, Glória Menezes, interpretando a Marquesa de Santos.

O cenário deveria ter sido outro em meus quatro anos de graduação universitária, cursados de 1983 a 1986, sobretudo porque fiz o curso de Comunicação Social, com habilitação em Jornalismo, em universidade na região do $A B C$ paulista. $E m$ tese, a linguagem audiovisual deveria estar na pauta de conteúdos disciplinares. E até estava, mas de maneira muito mais tímida e desarticulada do que seria razoável esperar. Nenhuma disciplina tratou pontualmente da história do cinema, da televisão e do vídeo - que, à época, articulava-se em novo campo, com relativa autonomia em relação aos anteriores ${ }^{82}$. Um ou outro professor recorria eventualmente a algum exemplo retirado

${ }^{82}$ Cf. ALMEIDA, 1984, e MACHADO, 1988. 
da produção audiovisual - ou seja, falava de um filme ou de um programa de TV - e um ou outro trabalho era feito pelos alunos em forma de imagens e sons.

Note-se que, a essa altura, havia um elemento facilitador, o videocassete -- e, se em casa podíamos ter um aparelho (ainda que emprestado por uma amiga da família para quem a novidade perdera o apelo), não me parece que colocar um à disposição dos professores fosse algo proibitivo. Os laboratórios de rádio e televisão da universidade dispunham de equipamentos, mas poucas vezes os utilizamos, e com restrições, como a proibição de uso de câmeras fora do campus. $O$ evento audiovisual mais significativo de que me lembro foi realizado à revelia da instituição: uma exibição clandestina, organizada pelo Centro Acadêmico, de Je vous salue, Marie, de JeanLuc Godard, que enfrentava problemas com a censura - já encerrado o regime militar, no governo José Sarney - e despertava forte represália de setores conservadores da sociedade ${ }^{83}$. Naquela noite, as salas de aula foram esvaziadas para prestigiar a sessão proibida. Cinema existia, era capaz de mobilizar jovens, desencadear debates, atuar socialmente. Aleluia.

Percebe-se por esse relato que não foi nas salas de aula da Educação Básica, tampouco nas do Ensino Superior, ainda em meus tempos de aluno, que eu soube da existência de um campo de estudos dedicado às relações entre o audiovisual e a educação. Mas foi cedo, embora não saiba precisar exatamente quando. Ainda na adolescência, passei a dedicar ao cinema uma atenção quase obsessiva. Assistia toda semana a diversos filmes nos cinemas, e quase todo dia a algum filme

\footnotetext{
${ }^{83}$ Lançado na França em janeiro de 1985, o longa Je vous salue, Marie enfrentou problemas - protestos, ameaças de censura e censura efetiva - para ser exibido comercialmente em diversos países, entre eles o Brasil, por sua releitura contemporânea da história bíblica de Maria (interpretada por Myriem Roussel).
} 
na televisão, registrando em cadernos minhas impressões. Leituras de críticas e do noticiário cinematográfico em jornais e revistas, bem como de livros de caráter introdutório, integraram esse pacote de descobertas. No início dos anos 1980, comecei a estudar cinema inicialmente, por meio de cursos sobre sua história e linguagem oferecidos pela Cinemateca Brasileira, na antiga sede próxima à estação Conceição do metrô, em São Paulo, onde assisti pela primeira vez a filmes de Humberto Mauro (1897-1983) e Glauber Rocha (19391981) - e a me exercitar na crítica em jornal de bairro paulistano (no qual passei também a trabalhar como repórter $)^{84}$. Essa profissionalização precoce contribuiu para que a sensibilidade em relação ao tema fosse despertada.

Nas últimas duas décadas, minhas atividades como professor universitário, jornalista e crítico de cinema convergiram em direção a leituras, pesquisas, produção de textos e organização de cursos, palestras e eventos que amadureceram minha visão sobre as oportunidades e os desafios oferecidos à presença do audiovisual na Educação Básica.

Quero destacar as seguintes experiências:

a) Cursos, palestras e debates nos projetos Escola no Cinema e Clube do Professor, mantidos pelo Espaço Unibanco de Cinema, em São Paulo. 0 primeiro envolve a realização de sessões de filmes, em geral acompanhadas de debates, especialmente para grupos de professores e alunos, e também a organização de cursos, exposições e de outros eventos voltados para o público escolar. O segundo projeto realiza sessões semanais e gratuitas de longas-metragens do circuito comercial, eventualmente acompanhadas de debates, exclusivamente para professores.

\footnotetext{
${ }^{84}$ Gazeta da Vila Prudente, então dirigido pelo jornalista Hirão Tessari.
} 
b) Palestras e debates no projeto Vivências Culturais para Educadores, organizado pelo Instituto Tomie Ohtake para a Secretaria Municipal de Educação de São Paulo. Durante os dois anos em que foi realizado, em 2002 e 2003, ministrei palestras e participei de debates com professores e gestores da rede municipal de ensino de São Paulo, para os quais eram dirigidas exclusivamente as atividades (em cinema, artes visuais, teatro e música).

c) Criação e coordenação - essa última, no período de implantação - de curso de especialização em Cinema e Educação em Goiânia (GO), a convite do grupo C.A.R.A. Vídeo - que reúne produtora de vídeo, rede de videolocadoras e centro cultural - e baseado em cursos e palestras sobre cinema e educação que passei a ministrar no estado a partir de 2003. Oferecido pela Universidade Estadual de Goiás em parceria com o Instituto de Filosofia e Teologia de Goiás (Ifiteg), o curso de especialização teve início no segundo semestre de 2006 e formou sua primeira turma em 2008. A segunda turma, agora sob responsabilidade acadêmica exclusiva do Ifiteg, ingressou no curso em $2009^{85}$.

d) Encontros do programa Diálogos \& Reflexões do Centro Cultural Banco do Brasil, em São Paulo. De março a dezembro de 2007, coordenei as atividades da área de Cinema do programa, que integrou naquele ano o projeto educativo da instituição. 0 público-alvo dos encontros, realizados quinzenalmente, era formado por educadores, o que propiciou tanto o uso do audiovisual em circunstâncias educacionais quanto nova experiência relacionada à qualificação de professores para uso do audiovisual. Os temas dos encontros eram pautados de acordo com os ciclos de cinema programados pelo CCBB, com o objetivo de discutir a linguagem e a história do cinema. No início

\footnotetext{
${ }^{85}$ Cf. o programa do curso no Apêndice C.
} 
das atividades, foi escrito por mim um livreto distribuído a todos os participantes durante os encontros.

e) Participação no Projeto Viração. Sou colunista e colaborador desde sua primeira edição - da revista Viração, a partir da qual foi estruturada a organização não governamental de mesmo nome, voltada para atividades no campo da educomunicação ${ }^{86}$. Criado em março de 2003, o projeto recebe apoio institucional do Fundo das Nações Unidas para a Infância (Unicef), da Organização das Nações Unidas para a Educação, a Ciência e a Cultura (Unesco), do Núcleo de Comunicação e Educação da Escola de Comunicação e Artes da Universidade de São Paulo e da Agência Nacional dos Direitos da Infância (Andi). Além de produzir as versões impressa e eletrônica da revista, a ONG oferece cursos e oficinas de capacitação em comunicação popular feita para jovens, por jovens e com jovens, em escolas, grupos e comunidades. Representantes de escolas públicas e particulares, projetos e movimentos sociais participam de conselhos editoriais jovens em 22 Estados.

f) Coordenação da oficina Crítica Curta, do Festival Internacional de Curtas-Metragens de São Paulo. Criado em 2005, o projeto consiste na produção de um jornal impresso e de um blog na internet, durante a realização do festival, com críticas dos filmes latinoamericanos exibidos em diversos de seus programas. Os textos são escritos pelos participantes da oficina -- em geral, jovens na faixa dos 17 aos 25 anos, e estudantes de cursos de Audiovisual e de Comunicação.

g) Atividade docente e participação em debates. Procuro transformar as minhas atividades docentes (que tiveram início em 1986, como professor de Técnicas de Redação no Primeiro Grau, e prosseguiram em cursos de graduação em Comunicação Social a partir

\footnotetext{
${ }^{86}$ www.viracao.org
} 
de 1991), sempre que possível e apropriado às circunstâncias, em laboratório de inserção do audiovisual em ambientes escolares. Nos últimos cinco anos, tenho feito isso como professor nos cursos de graduação em Jornalismo e Letras da Universidade Presbiteriana Mackenzie, nos cursos de especialização em Crítica Cinematográfica, em Jornalismo Cultural e em Jornalismo Esportivo da FAAP - Fundação Armando Álvares Penteado, em cursos livres sobre a história e a linguagem do cinema na Casa do Saber, e no curso técnico em Direção Cinematográfica - Filmworks da Academia Internacional de Cinema. Meus alunos nessas instituições são permanentes interlocutores na avaliação de práticas do audiovisual na educação. Além dessas atividades regulares, tenho organizado cursos de curta duração, participado de debates sobre o tema em diversas cidades e visitado escolas para encontros com professores e alunos.

h) Publicação de artigos e atividade jornalística. Como jornalista, tenho escrito textos que promovem reflexões sobre as conexões entre o audiovisual e a educação, como os publicados na revista Educação ${ }^{87}$, de que fui editor e da qual sou colunista de Cultura, na revista Língua Portuguesa $^{88}$, em que criei a coluna de Cinema, e na coluna Cinema Sustentável da revista Ideia Sustentáve ${ }^{\beta 9}$. Além disso, entendo a crítica cinematográfica como atividade de pesquisa (logo, o crítico como um pesquisador) e de formação do público, de acordo com a breve (e aguda) definição do crítico francês André Bazin (1918-1958), um dos criadores e editores da revista Cahiers du Cinéma:

A função do crítico não é trazer numa bandeja de prata uma verdade que não existe, mas prolongar o máximo

\footnotetext{
${ }^{87}$ www.revisteducacao.com.br

${ }^{88}$ www.revistalingua.com.br

${ }^{89}$ www.ideiasustentavel.com.br
} 
possível, na inteligência e na sensibilidade dos que o leem, o impacto da obra de arte. (BAZIN, 1991, p. 5)

Penso que essa visão pode ser estendida, com as devidas adaptações circunstanciais, aos profissionais que trabalham com 0 audiovisual na escola.

i) Viagens profissionais ao exterior, que possibilitaram realizar pesquisas bibliográficas e entrar em contato com experiências relevantes sobre audiovisual e educação na Argentina, no Chile, na Espanha, nos EUA, na França, na Inglaterra e em Portugal.

Essas atividades me levaram a conhecer numerosos exemplos em que o audiovisual está presente no ambiente escolar, a despeito, em muitos casos, da falta de formação específica do docente e da infraestrutura (equipamentos, espaços, acervos) deficiente. Conheci também programas desenvolvidos por redes de ensino ou escolas isoladas que procuraram e procuram institucionalmente cumprir a tarefa de oferecer mínima qualificação humana e técnica aos profissionais interessados nessa especialização.

Tenho certeza de que as conexões entre o audiovisual e a educação no Brasil já não mais equivalem, em amplo espectro geográfico, à suposta presença de extraterrestres entre nós: venho comprovando, com satisfação, que dificilmente um aluno de Educação Básica passaria hoje por situação semelhante à que experimentei, ou deixei de experimentar, na infância e adolescência. De um lado, novas gerações de professores são mais próximas da cultura audiovisual principalmente por conta da exposição à TV desde a infância - do que as gerações que trabalhavam na Educação Básica nos anos 1970 e início dos anos 1980. De outro, a instalação de equipamentos audiovisuais nas escolas, intensificada na última década, combina-se 
com a ênfase no uso de novas tecnologias em sala de aula para tornar o cenário mais favorável.

Em maior ou menor grau, de maneira organizada ou não, o audiovisual passou a ser contemplado pela escola. Penso que já não cabe tentar "escolarizá-lo", ou seja, determinar apenas uma porta, em forma de disciplina, pela qual obrigatoriamente ingresse no sistema educacional. Ele já foi incorporado, em diversas práticas - inclusive, em algumas escolas, pela mais tradicional das portas, em forma de disciplina. Não seria exagero considerar que a experiência formadora relatada na epígrafe desta introdução por Italo Calvino possa agora ser mediada, em muitos casos, pela educação formal. Alunos dos 5,1 mil municípios brasileiros que não dispõem de salas de cinema talvez dependam da escola para serem apresentados a essa modalidade de vivência cultural coletiva ${ }^{90}$.

Acredito, por outro lado, que as transformações registradas nas últimas décadas tornam oportuna, talvez obrigatória, a revisão dos conceitos que tradicionalmente orientaram essas práticas, bem como recomendam, a instituições de formação de educadores e a redes de ensino interessadas na qualificação de profissionais para atuação nessa área, a adoção de políticas de formação sintonizadas com as especificidades do cenário audiovisual hoje. A proposta de curso de especialização formulada neste trabalho constitui um dos possíveis caminhos para abordar o tema.

\footnotetext{
90 De acordo com dados do Observatório Brasileiro do Cinema e do Audiovisual, mantido pela Agência Nacional do Cinema (Ancine), apenas 377 dos 5.565 municípios brasileiros tinham salas de cinema em 2009. Esses 377 municípios totalizavam 99,1 milhões de habitantes, cerca de $53 \%$ da população do país naquele ano.
} 
O curso de especialização configurado neste trabalho pode ser oferecido também de acordo com a duração mínima estabelecida pela Câmara de Educação Superior do Conselho Nacional de Educação para essa modalidade, de 360 horas. Nesse caso, a carga horária de cada disciplina e a sua distribuição pelos módulos corresponderiam ao estabelecido nos quadros deste apêndice. 
I. Organização por eixos temáticos

\begin{tabular}{|c|c|}
\hline $\begin{array}{l}\text { Eixos temáticos } \\
\text { (carga horária) }\end{array}$ & $\begin{array}{l}\text { Disciplinas } \\
\text { (carga horária) }\end{array}$ \\
\hline $\begin{array}{l}\text { História da educação } \\
\text { audiovisual (78) }\end{array}$ & $\begin{array}{l}\text { * Cinema, TV e educação (39) } \\
\text { * Mídia, infância e juventude (18) } \\
\text { * Fundamentos da educomunicação e } \\
\text { ecossistemas comunicacionais (21) }\end{array}$ \\
\hline $\begin{array}{l}\text { Leituras do } \\
\text { audiovisual } \\
\text { (90) }\end{array}$ & $\begin{array}{l}\text { * Fundamentos da crítica do audiovisual (21) } \\
\text { * Laboratório de crítica I (18) } \\
\text { * Laboratório de crítica II (18) } \\
\text { * Laboratório de crítica III (18) } \\
\text { * Audiovisual e representação (15) }\end{array}$ \\
\hline $\begin{array}{l}\text { Política e economia } \\
\text { do audiovisual ( } 21)\end{array}$ & * Política e economia do audiovisual (21) \\
\hline $\begin{array}{l}\text { Audiovisual e } \\
\text { cibercultura (33) }\end{array}$ & $\begin{array}{l}\text { * Ciberespaço, cibercultura e redes (21) } \\
\text { * Produção audiovisual e meios digitais (12) }\end{array}$ \\
\hline $\begin{array}{l}\text { Estratégias de } \\
\text { educação audiovisual } \\
\text { (138) }\end{array}$ & $\begin{array}{l}\text { * Planejamento pedagógico para a educação } \\
\text { audiovisual (33) } \\
\text { * Programação e mediação do audiovisual na } \\
\text { escola (33) } \\
\text { * Realização audiovisual I (24) } \\
\text { * Realização audiovisual II (24) } \\
\text { * Realização audiovisual III (24) }\end{array}$ \\
\hline
\end{tabular}


Il. Organização por módulos semestrais

\begin{tabular}{|c|c|}
\hline $\begin{array}{l}\text { Módulos } \\
\text { semestrais } \\
\text { (carga horária) }\end{array}$ & Disciplinas (carga horária) \\
\hline Primeiro (120) & $\begin{array}{l}\text { * Cinema, TV e educação (39) } \\
\text { * Mídia, infância e juventude (18) } \\
\text { * Fundamentos da crítica do audiovisual (21) } \\
\text { * Laboratório de crítica I (18) } \\
\text { * Realização audiovisual I (24) }\end{array}$ \\
\hline Segundo (120) & $\begin{array}{l}\text { * Fundamentos da educomunicação e } \\
\text { ecossistemas comunicacionais (21) } \\
\text { * Audiovisual e representação (15) } \\
\text { * Política e economia do audiovisual (21) } \\
\text { * Ciberespaço, cibercultura e redes (21) } \\
\text { * Laboratório de crítica II (18) } \\
\text { * Realização audiovisual II (24) }\end{array}$ \\
\hline Terceiro (120) & $\begin{array}{l}\text { * Produção audiovisual e meios digitais (12) } \\
\text { * Planejamento pedagógico para a educação } \\
\text { audiovisual (33) } \\
\text { * Programação e mediação do audiovisual na } \\
\text { escola (33) } \\
\text { * Laboratório de crítica III (18) } \\
\text { * Realização audiovisual III (24) }\end{array}$ \\
\hline
\end{tabular}


A seguir, o programa disciplinar apresentado ao Ministério da Educação para aprovação do curso de especialização em Cinema e Educação organizado pelo autor desta pesquisa para a Universidade Estadual de Goiás e para o Instituto de Filosofia e Teologia de Goiás (Ifiteg), que o lançaram em parceria, em Goiânia (GO). A primeira turma do curso ingressou no segundo semestre de 2006 e formou-se em 2008.

\section{Carga horária disciplinar}

288 horas/aula

\section{Estrutura}

8 disciplinas (módulos) de 36 horas/aula cada

\section{Apresentação}

Criado no final do século XIX, o cinema se estabeleceu como o principal espetáculo de massas do século $X X$, cujo desenvolvimento acompanhou, espelhou e influenciou, tanto no documentário como na ficção. Não se consegue escrever a história dos últimos 100 anos sem fazer referência à presença das imagens em movimento na sociedade ocidental. A televisão, o vídeo e as artes digitais devem a ele a criação e o desenvolvimento da linguagem audiovisual.

Incentivar a apreciação do cinema por educadores tem, em primeiro lugar, a missão de iluminar devidamente as condições materiais e ideológicas segundo as quais a produção cinematográfica nasceu e se desenvolveu, até afirmar-se como ponta de lança da 
indústria cultural. Professores são, antes de tudo, espectadores. Diante da cultura das imagens que nos rodeia, é imprescindível que somem, ao hábito de assistir a filmes, a postura de inseri-los em seu devido contexto histórico-cultural e submetê-los a seu espírito crítico.

Além disso, é preciso que se qualifiquem para discutir e explorar filmes com seus alunos, expostos hoje a um elevado consumo de imagens em movimento, que thes vale um repertório audiovisual às vezes superior ao de seus pais e mestres. O conhecimento sistematizado do cinema ajuda o educador a compreender o cenário da cultura, dos meios de comunicação de massa e dos processos de transmissão de informações na sociedade contemporânea.

\section{Objetivos}

Demonstrar as possibilidades de uso do cinema como ferramenta pedagógica, em disciplinas, projetos interdisciplinares ou multidisciplinares de todos os níveis do ensino formal; analisar a linguagem dos meios audiovisuais e seu impacto crescente sobre as novas gerações.

\section{Metodologia}

Aulas expositivas, exibição de curtas e longas-metragens, debates, exercícios práticos de análise e de programação de filmes.

\section{Atividades práticas}

Ao longo do curso, os professores vão produzir análises de filmes e serão apresentados aos procedimentos básicos para montar o roteiro de aulas ou atividades extracurriculares que façam uso do cinema. Ao final, desenvolvidos conhecimentos sobre formação de 
repertório, análise, condução de debates e programação, eles deverão apresentar, individualmente, o planejamento detalhado de um ciclo de filmes em torno de tema a ser definido por cada um deles.

\section{PROGRAMA}

\section{Módulo 1 - 0 cinema como prática social}

Introdução à história do cinema, de espetáculo circense a ponta de lança da indústria cultural.

A indústria cinematográfica americana e a consolidação do cinema narrativo clássico.

O cinema de arte e as tentativas de resistência à hegemonia hollywoodiana.

O cinema como principal manifestação da cultura de massas do século 20.

A educação do olhar do espectador.

A criação e consolidação da linguagem audiovisual que contribuiu para o desenvolvimento da TV.

A difusão de valores e modos de vida: os filmes "ensinam" o público.

O professor como espectador: memórias afetivas do cinema.

\section{Módulo 2 - Como interpretar filmes}

Introdução às diversas abordagens de análise do cinema: história, principais conceitos, bibliografia de referência.

Como lidar com as fontes de informação: jornais, revistas, livros, web sites. 
A consolidação da indústria cinematográfica: o "gênio do sistema" como o realizador impessoal e invisível de filmes.

A integração entre as áreas de atuação envolvidas na realização de filmes como pressuposto de qualidade técnica: produção, direção, roteiro, fotografia, montagem, direção de arte e cenografia, trilha sonora.

O surgimento e desenvolvimento dos gêneros na indústria cinematográfica, o reconhecimento dos formatos pelo público e as implicações sobre o mercado distribuidor e exibidor de cinema, que se estendem, hoje, ao vídeo e ao DVD.

A "política dos autores" defendida pelos críticos da revista francesa Cahiers du Cinéma, a consolidação do diretor como autor de filmes a partir dos anos 1950 e a assimilação desse conceito pelas estratégias de marketing da indústria cinematográfica.

O diálogo entre a ficção e o documentário, a exploração de modelos narrativos que incorporam procedimentos de outros meios de comunicação e artes, e a busca pela síntese audiovisual da experiência na sociedade industrial e globalizada.

\section{Módulo 3 - Cinema e literatura}

Tradução ou traição: os principais desafios da transposição de uma obra de um meio para outro. Cinema d'art: o "teatro filmado".

Roteiros como obras literárias autônomas.

Os procedimentos básicos para analisar filmes baseados em obras literárias, segundo Geoffrey Wagner.

Categorias de adaptação: a transposição, o comentário e a analogia. 


\section{Módulo 4 - Cinema e História}

Como os filmes tratam fatos, personagens e circunstâncias históricas na construção de um "passado imperfeito".

Procedimentos de análise que permitem identificar ênfases e distorções.

A História como fonte/matéria-prima para o cinema.

Filmes como releituras da História e fontes de pesquisa: reconstituição de fatos, personagens, estudos de época, vida cotidiana.

A investigação dos indícios históricos na produção cinematográfica de períodos e autores específicos: o cinema nazista, o cinema norte-americano durante a II Guerra Mundial, o Cinema Novo brasileiro e o regime militar de 1964, a Inglaterra do pós-guerra em Desencanto.

A releitura da história no documentário.

\section{Módulo 5 - Cinema e psicologia}

Como os filmes recorrem a fundamentos psicológicos e psicanalíticos na construção de personagens e no desenvolvimento de tramas.

Os conceitos de psicologia e a estratégia naturalista em busca da verossimilhança e da credibilidade no cinema de ficção.

Os mecanismos de identificação entre espectador e personagens: a estratégia de catarse.

O ser humano simplificado: as estratégias de causa-e-efeito do cinema de ficção.

O cinema como exemplo: máquina para reprodução de comportamentos. 
Psicólogos, terapeutas, psicanalistas e o espaço terapêutico como fontes de argumentos para filmes.

O uso do cinema na terapia: a experiência dos psicólogos americanos John e Jan Hesley.

\section{Módulo 6 - Cinema e infância}

Os filmes de formação e sobre os ritos de passagem.

A simplificação hollywoodiana: a criança como geniozinho circense ou ferramenta para provocar lágrimas.

A idealização da infância.

A infância como olhar de contraponto ao mundo adulto.

A infância como sofrimento e como pesadelo.

Paulo Emílio Salles Gomes e a inocência do cinema.

A exposição de crianças e jovens à violência das imagens: a representação da violência no cinema ao longo do século XX.

A violência das imagens: as três hipóteses de Olivier Mongin.

\section{Módulo 7 - Cinema e religião}

O cinema como religião.

O "star system" e a criação de seus objetos de devoção.

Salas de cinema como templos e espectadores como devotos.

A fé no artifício: a "suspenção da descrença".

O cinema de ficção como compensação da realidade vivida, e também oportunidade de refletir sobre ela: a transcendência e a experiência transrrealista fundada em processo de identificação.

O cinema e a recriação de episódios religiosos.

O cinema narrativo e a "jornada do herói": as idéias de Joseph Campbell. 
Cineastas fundamentais para a discussão religiosa no cinema ocidental.

\section{Módulo 8 - 0 cinema e a escola}

A presença do cinema na educação.

O uso de filmes como apoio à apresentação e discussão de conteúdos.

Planejamento de atividades.

Desenvolvimento de projetos com as seguintes ênfases:

- o cinema como ferramenta paradidática;

- o cinema como reflexão sobre a educação e processos educacionais, formais ou informais;

- o cinema na perspectiva de educação do olhar: alfabetização de espectadores para um mundo de estímulos audiovisuais;

- o cinema como ponto de partida para conexões com o mundo: debates, palestras;

- o cinema como "o sonho que todos sonhamos juntos" e as realidades compartilhadas em grupos sociais: a escola vai ao cinema.

\section{BIBLIOGRAFIA}

\section{Iniciação}

ALMEIDA, Milton José de. Imagens e sons: a nova cultura oral. São Paulo: Cortez, 1994.

ARAUJO, Inacio. Cinema: o mundo em movimento. São Paulo: Scipione, 1995.

BERNARDET, Jean-Claude. 0 que é cinema. São Paulo: Brasiliense, 1980. 
MERTEN, Luiz Carlos. Cinema: um zapping de Lumière a Tarantino. Porto Alegre: Artes e Ofícios, 1995.

História, linguagem, teoria, educação

ARNT, Héris e HELAL, Ronaldo (Org.). A sociedade na tela do cinema. Rio de Janeiro: E-Papers, 2002.

AUMONT, Jacques (Org.). A estética do filme. Campinas: Papirus, 1995.

BAZIN, André. 0 cinema: ensaios. São Paulo: Brasiliense, 1991.

BERNARDET, Jean-Claude. 0 autor no cinema. São Paulo: Brasiliense, 1994.

- Cinema brasileiro: propostas para uma história. Rio de Janeiro: Paz e Terra, 1979.

BOGDANOVICH, Peter. Afinal, quem faz os filmes. São Paulo: Companhia das Letras, 2000.

BURGOYNE, Robert. A nação do filme: Hollywood examina a história dos Estados Unidos. Brasília: Ed. da UnB, 2002.

CALVINO, Italo. "Autobiografia de um espectador". In: 0 caminho de São Giovanni. São Paulo: Companhia das Letras, 2000.

CARNES, Mark C. (Org.). Passado imperfeito: a história no cinema. Rio de Janeiro: Record, 1997.

CASTRO, Nilo André Piana de (Org.). Cinema e Segunda Guerra. Porto Alegre: Ed. da UFRG, 1999.

CHARNEY, Leo; SCHWARTZ, Vanessa. O cinema e a invenção da vida moderna. São Paulo: Cosac \& Naify, 2001.

CITELLI, Adilson (Org.). Outras linguagens na escola. São Paulo: Cortez, 2001.

DANCYGER, Ken. Técnicas de edição para cinema e vídeo: história, teoria e prática. Rio de Janeiro: Elsevier/Campus, 2003. 
FEILITZEN, Cecilia Von; CARLSSON, Ulla (Org.). A criança e a mídia: imagem, educação, participação. São Paulo: Cortez Editora/Unesco, 2002.

FRANCE, Claudine de. Cinema e antropologia. Campinas: Ed. da Unicamp, 1998.

MANNONI, Laurent. A grande arte da luz e da sombra: arqueologia do cinema. São Paulo: Ed. Senac/Unesp, 2003.

MARTIN, Marcel. A linguagem cinematográfica. São Paulo: Brasiliense, 1990.

MOCELIN, Renato. 0 cinema e o ensino da história. Curitiba: Nova Didática, 2002.

MONGIN, Olivier. A violência das imagens: ou como eliminá-la?. Lisboa: Bizâncio, 1998.

NAGIB, Lúcia. 0 cinema da retomada: depoimentos de 90 cineastas dos anos 90. São Paulo: Ed. 34, 2002.

NAPOLITANO, Marcos. Como usar o cinema na sala de aula. São Paulo: Contexto, 2003.

NAZÁRIO, Luiz. As sombras móveis: atualidade do cinema mudo. Belo Horizonte: UFMG, 1999.

ORICCHIO, Luiz Zanin. Cinema de novo: um balanço crítico da retomada. São Paulo: Estação Liberdade, 2003.

RAMOS, Fernão (Org.). História do cinema brasileiro. São Paulo: Art Editora, 1987.

; MIRANDA, Luiz Felipe. Enciclopédia do cinema brasileiro. São Paulo: Senac, 2001.

SOARES, Mariza de Carvalho (Org.). A história vai ao cinema. Rio de Janeiro: Record, 2001.

TARDY, Michel. 0 professor e as imagens. São Paulo: Cultrix/Edusp, 1976. 
VIANY, Alex. Introdução ao cinema brasileiro. Rio de Janeiro: MEC/Instituto Nacional do Livro, 1959.

XAVIER, Ismail (Org.). A experiência do cinema. Rio de Janeiro: Graal, 1983.

XAVIER, Ismail (Org.). O cinema no século. Rio de Janeiro: Imago, 1996.

\section{Referência}

AUMONT, Jacques; MARIE, Michel. Dicionário teórico e crítico de cinema. Campinas: Papirus, 2003.

EWALD FILHO, Rubens. Dicionário de cineastas. São Paulo: Companhia Editora Nacional, 2002.

MIRANDA, Luiz F. A. Dicionário de cineastas brasileiros. São Paulo: Art Editora, 1990.

SCHATZ, Thomas. O gênio do sistema: a era dos estúdios em Hollywood. São Paulo: Companhia das Letras, 1991.

SILVA NETO, Antonio Leão da. Astros e estrelas do cinema brasileiro: dicionário de atrizes e atores. São Paulo: edição do autor, 1998.

. Dicionário de filmes brasileiros. São Paulo: edição do autor, 2002.

TULARD, Jean. Dicionário do cinema: os diretores. Porto Alegre, L\&PM, 1996. 